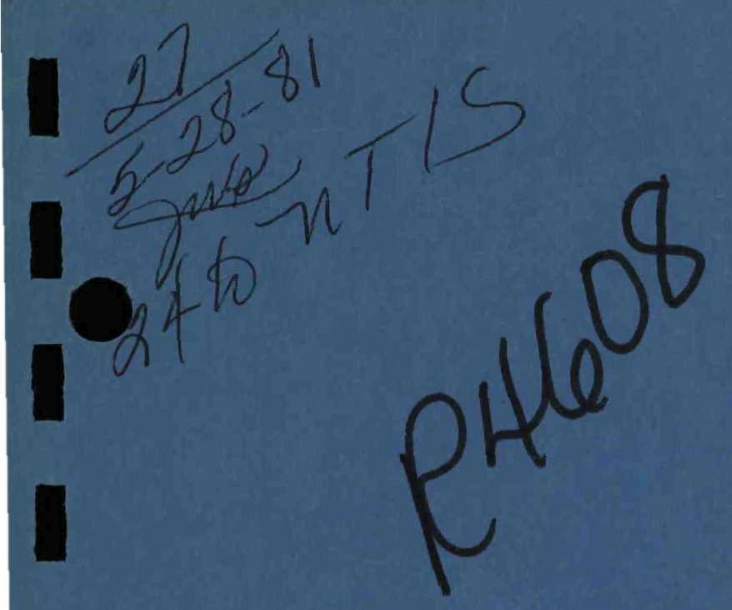

Advanced Energy Systems Division

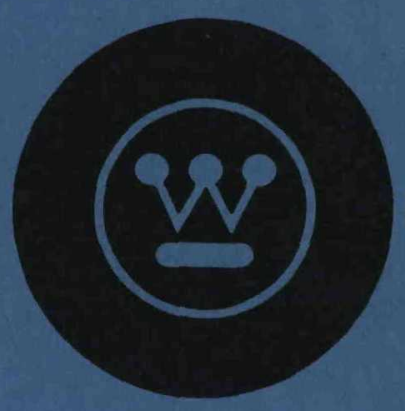

Spent Fuel Dry Storage Technology Development:

THERMAL EVALUATION OF SEALED STORAGE CASK CONTAINING SPENT FUEL

\author{
P.F. Schmitten \\ J.B. Wright \\ Prepared For \\ THE UNITED STATES DEPARTMENT OF ENERGY \\ Contract No. DE-AC08-76NV00597
}

AUGUST 1980

Westinghouse Electric Corporation Advanced Energy Systems Division

P.O. Box 10864

Pittsburgh,Pennsylvania 15236 


\section{DISCLAIMER}

This report was prepared as an account of work sponsored by the United States Government. Neither the United States nor the United States Department of Energy, nor any of their employees, makes any warranty, express or implied, or assumes any legal liability or responsibility for the accuracy, completeness, or usefulness of any information, apparatus, product, or process disclosed, or represents that its use would not infringe privately owned rights. Reference herein to any specific commercial product, process, or service by trade name, mark, manufacturer, or otherwise, does not necessarily constitute or imply its endorsement, recommendation, or favoring by the United States Government or any agency thereof. The views and opinions of authors expressed herein do not necessarily state or reflect those of the United States Government or any agency thereof.

Printed in the United States of America

Available from:

National Technical Information Service

U. S. Department of Commerce

5285 Port Royal Road

Springfield, Virginia 22161

Price: Printed Copy $\$ 11.00$

Microfiche $\$ 3.50$ 


\section{DISCLAIMER}

This report was prepared as an account of work sponsored by an agency of the United States Government. Neither the United States Government nor any agency Thereof, nor any of their employees, makes any warranty, express or implied, or assumes any legal liability or responsibility for the accuracy, completeness, or usefulness of any information, apparatus, product, or process disclosed, or represents that its use would not infringe privately owned rights. Reference herein to any specific commercial product, process, or service by trade name, trademark, manufacturer, or otherwise does not necessarily constitute or imply its endorsement, recommendation, or favoring by the United States Government or any agency thereof. The views and opinions of authors expressed herein do not necessarily state or reflect those of the United States Government or any agency thereof. 


\section{DISCLAIMER}

Portions of this document may be illegible in electronic image products. Images are produced from the best available original document. 


\title{
Spent Fuel Dry Storage Technology Development: THERMAL EVALUATION OF SEALED STORAGE CASK CONTAINING SPENT FUEL
}

\author{
P.F. Schmitten \\ J.B. Wright \\ Prepared For \\ THE UNITED STATES DEPARTMENT OF ENERGY \\ Under Contract No. DE-AC08-76NVOO597
}

AUGUST 1980

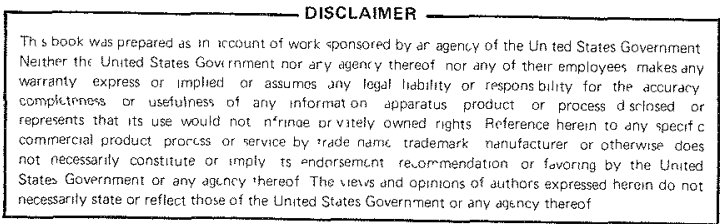

WESTINGHOUSE ELECTRIC CORPORATION

Advanced Energy Systems Division

P.O. Box 10864

Pittsburgh, Pennsylvania 15236 


\section{ACKNOWLEDGMENTS}

The authors wish to thank those who contributed to the development of this document.
C.A. Holder
P.S. Sherba
W.L. Lundberg
R.Unterzuber 
ABSTRACT

The spent fuel Sealed Storage Cask (SSC) Test is presently being conducted at the Engine-Maintenance, Assembly and Disassembly (E-MAD) facility on the Nevada Test Site. A pressurized water reactor spent fuel assembly was encapsulated inside the E-MAD Hot Bay and placed in a instrumented above surface storage cell during December 1978 for thermal testing. The fuel assembly was sealed inside a stainless steel canister and attached to a concrete filled steel shield plug. The canister assembly was then placed in a carbon steel liner which is encased in a reinforced concrete shield cask. The SSC was then transferred outside to a foundation pad adjacent to E-MAD.

Instrumentation provided to measure canister, liner and concrete temperatures consisted of thermocouples which were inserted into tubes on the outside of the canister and liner and in three radial positions in the concrete. Temperatures from the SSC test assembly have been recorded throughout the past 16 months. Canister and liner temperatures have reached their peak values of $200^{\circ} \mathrm{F}$ and $140^{\circ} \mathrm{F}$, respectively.

A computer model was developed to predict the thermal response of the test configuration. Computer predictions of the transient and steady-state temperatures of the SSC components and surrounding concrete are presented and they show good agreement with the test data. 
1.0 INTRODUCTION

1.1 Purpose of Report

1.2 Organization of Report

1.3 Background

2.0 CONCLUSIONS

4.0 TEST HARDWARE DESCRIPTION

4.1 Test Arrangement 8

4.2 SSC Liner 8

4.3 Canister Assembly 18

4.4 PWR Spent Fuel Assembly 25

4.5 Storage Site 28

4.6 Seal Storage Cask Assembiy 33

4.7 Data Acquisition System 38

5.0 TEST OPERATIONS AND RESULTS 41

5.1 Test Operations . 41

5.2 Test Results 41

5.3 Ambient Temperature Measurements 49

6.0 THERMAL ANALYSIS MODEL 51

6.1 Analysis Purpose and Method 51

6.2 Model Description 52 
TABLE OF CONTENTS

\subsection{THERMAL ANALYSIS RESULTS}

7.1 Model Evaluation Criteria

7.2 Model/Data Comparison

8.0 REFERENCES

APPENDIX A SEALED STORAGE CASK TEST DATA

APPENDIX B TAP-A INPUT AND OUTPUT

APPENDIX C THERMAL CONDUCTIVITY OF CONCRETE EVALUATIONS
Page No. 62

62.

62

67

$68-84$

$85-112$

$113-117$ 
Table No.

1

2

3

4

5

6
Title

Page No.

$15-17$

50

E-MAD During Test Period

SSC TAP-A Model Node Description

54

Thermal Conductivity Coefficients

58

Representing Convection and Conduction at Various SSC Interfaces

Material Thermal Properties Used

60

in Analys is

SSC \#2 Concrete Properties 


\section{LIST OF FIGURES}

FIGURE NO.
TITLE

Sealed Storage Cask Configuration

SSC Schematic

SSC Liner Section View

Sealed Storage Cask Liners Prior to Shipping

Sealed Storage Cask Liners on Pads During Rebar Installation

Sealed Storage Cask Rebar Installation Completed Prior to Concrete Pouring

Canister Configuration

Canister Closure Lid Configuration

Shield Plug Configuration

Canister and Concrete Shield Plug Mating

PWR Fuel Assembly Configuration

Predicted Decay Heat After Shutdown for Turkey Point PWR Spent Fuel Assemblies

PWR Fuel Assembly Being Installed into Canister E-MAD Storage Site Configuration

29

30

Sealed Storage Cask Foundation

SSC and Drywell Storage Area Construction

Completed Canister Being Remotely Lowered Into Sealed Storage Cask in Hot Bay

Sealed Storage Cask with Canister Being Lowered onto Storage Pad

Data Logger Installation in West Gallery

Maximum Temperature Distribution, Weekly

Intervals, $45^{\circ} \mathrm{NE}$ quadrant, Elevation $128^{\prime \prime}$

43

July 24, 1979 to July 27, 1979, Elevation 128", $45^{\circ} \mathrm{NE}$ Quadrant 


\section{LIST OF FIGURES (CONTINUED)}

FIGURE NO.

22

23

24

25

26

27

28

29

30

31
TITLE

Axial Temperature Distribution on July 24, 1979

(5427 Hours), Temperatures Averaged for 24 Hours

Isotherms on July 24, 1979 (5427 Hours)

Temperature Distribution at 4 Hour Intervals January 29, 1980 to February 3, 1980, Elevation $128^{\prime \prime}$, 45ํ Quadrant

Axial Temperature Distribution on January 30,1980 (9979 Hours), Temperatures Averaged for 24 Hours

Isotherms on January 30, 1980 (9979 Hours)

Sealed Storage Cask Thermal Model

Thermal Conductivity within Modeled Fuel Assembly

Test Data and Predictions Comparison of Monthly Average Midplane (Elevation 128") Temperatures

Test Data and Predictions Comparison of Axial Temperature Distribution on July 24, 1979 (5427 Hours)

Test Data and Predictions Comparison of Radial Temperature Distribution at Elevation 128" on JuTy 24, 1979 (5427 Hours)
45

48

53

55

PAGE NO.

44

46

47

63

64

66 


\subsection{INTRODUCTION}

\subsection{PURPOSE OF REPORT}

The purpose of this report is to provide a test description, test results, and the conclusions for the spent fuel Sealed Storage Cask (SSC) Test performed at the E-MAD facility on the Nevada Test Site. This test was conducted as part of the Spent Fuel Handling and Packaging Program (SFHPP) 1978 Demonstration (further discussed in Section 1.3). The primary test objective was to confirm by actual testing that commercial reactor spent fuel could be passively stored in an above ground storage cell at the Nevada Test Site.

The SSC Test was begun on December 7, 1978 when a pressurized water reactor (PWR) spent fuel assembly was placed into an SSC and transferred to a storage pad near the E-MAD facility. The test hardware (shown in Figure 1) consisted of an instrumented carbon steel liner, an instrumented stainless steel canister (containing the spent PWR fuel assembly), a concrete-filled shield plug which supported the canister from the top of the liner and an instrumented reinforced concrete shield. Throughout the test period, temperature readings from thermocouples on the canister, liner and in the concrete were recorded. Strain gages were also embedded in the concrete shield and were recorded during the test period. Interpretation of the strain gage data is not included in this report. A finite difference computer model (described in Section 6.0) was developed to predict SSC and canister transient and long term temperatures. Comparisons of the analytical predictions with the test data are presented in Section 7.0 .

\subsection{ORGANIZATION OF REPORT}

This report is organized to present the SSC Test and its results in the following order:

- Introduction (including background of Spent Fuel Handling and Packaging Program 1978 Demonstration) 


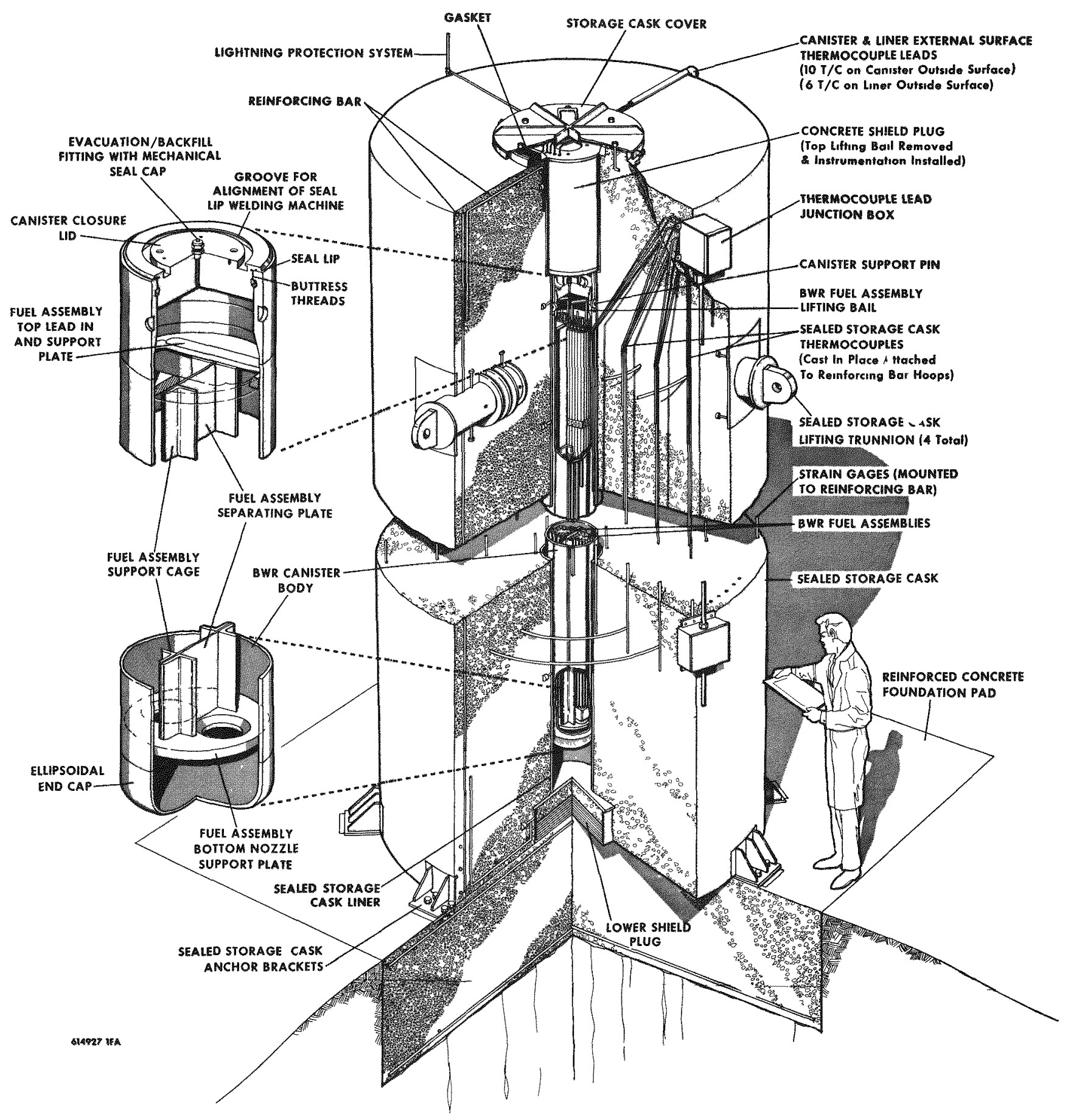

Figure 1. Sealed Storage Cask Configuration 
- Conclusions drawn from the test results

- Test objectives

- Test hardware description

- Test operation and results

- Thermal model description

- Comparison of test results with model predictions

\subsection{BACKGROUND}

The SSC Test described in this report is being conducted as part of the Spent Fuel Handling and Packaging Program (SFHPP) 1978 Demonstration. The objective of the SFHPP 1978 Demonstration was to develop the capability to encapsulate typical spent fuel assemblies from commercial nuclear power plants and to establish by testing the suitability of one or more surface and near-surface concepts for the interim dry storage of the encapsulated fuel assemblies.

The E-MAD (Engine-Maintenance, Assembly, and Disassembly) facility, constructed at the Nevada Test Site as part of the Nuclear Rocket Development Station, was chosen as the location for this demonstration because of its extensive existing capabilities for handling highly radioactive components and because of the desirable site characteristics for the proposed storage concepts. The E-MAD facility, operated for the Department of Energy by the Advanced Energy Systems Division of the Westinghouse Electric Corporation, is described in more detail in Reference 1 .

Near surface and above surface storage concepts were chosen for testing during the SFHPP 1978 Demonstration. Each storage cell is designed to accommodate one canister, and the canister is designed to contain either one PWR fuel assembly or two boiling water reactor (BWR) fuel assemblies. The near surface storage concept or drywe11, Reference 2, consists of a steel liner grouted into a shallow hole drilled in the alluvial soil at the E-MAD facility. A sealed canister containing the fuel assembly in a helium atmosphere is suspended from a shield plug which in turn is supported by a step in the liner. The above 
ground storage concept, Sealed Storage Cask (SSC), is shown in Figure 1. A steel liner similar to that used in the drywell is encased in a reinforced concrete silo, and the canister/shield plug package is supported in the liner in the same manner as in the drywe11. In both of these storage systems, the decay heat of the fuel assembly is passively dissipated to the environment. Encapsulation of the fuel assemblies was performed inside the shielded Hot Bay of the E-MAD facility. The drywell and SSC storage cells were constructed in an area adjacent to the facility.

An overriding requirement for the SFHPP 1978 Demonstration Program was that the spent fuel storage system and associated activities not result in an undue risk to the public, property, environment, or site employees. One means of assuring that this requirement would be met was to maintain the leak tight integrity of the fuel cladding and the canister. Because high temperature can affect the long term integrity of both of these barriers to fission product release, thermal considerations were an important concern in the design of the storage cells. Preliminary analyses performed by the Hanford Engineering Development laboratory (HEDL) established $715^{\circ} \mathrm{F}\left(380^{\circ} \mathrm{C}\right)$ as the fuel cladding temperature limit below which fuel cladding integrity would be maintained in a helium environment for long storage times (100 years). Scoping thermal analysis of the storage cell concepts indicated that cladding temperatures reached in the SSC would be well below the limit for the fuel assembly decay heat levels being considered.

The storage cell experiments consisted of encapsulating spent fuel assemblies and placing them in storage with thermocouple instrumentation on the exterior of the fuel storage canister and throughout the storage cell. The fuel assemblies selected were characteristic of high burnup (25,000 MWD/MTU) fuel assemblies approximately three years out of the reactor with a thermal power level of approximately $1.25 \mathrm{~kW}$. Fuel encapsulations were performed at E-MAD during December 1978 and January 1979. An encapsulated PWR assembly was placed in a Sealed Storage Cask on December 7, 1978 and two other encapsulated PWR fuel assemblies were placed in drywells on January 12 and 24, 1979. These 
experiments are still in progress. The on-going SSC test is the subject of this report. 


\subsection{CONCLUSIONS}

The following conclusions can be drawn from the results of the SSC test:

1. The peak measured canister temperature for an encapsulated PWR spent fuel assembly with an initial decay heat level of $1.1 \mathrm{~kW}$ stored in an SSC configuration at the Nevada Test Site was $201^{\circ} \mathrm{F}$. The peak concrete temperature adjacent to the liner was $141^{\circ} \mathrm{F}$.

2. Seasonal variations in ambient air temperatures and solar radiation have a significant effect on the canister temperature. The peak canister temperature is in the order of $115^{\circ} \mathrm{F}$ above the average monthly ambient temperature (yearly range is $37^{\circ} \mathrm{F}$ to $83^{\circ} \mathrm{F}$ ).

3. Day-night variations in ambient air temperature are essentially damped out within the first 15 inches of concrete.

4. The computer thermal model provides predictions of the concrete temperature distribution in close agreement with the test data. 


\subsection{TEST OBJECTIVES}

As originally planned, the objectives of the spent fuel SSC Test were 1) to verify that spent fuel assemblies can be safely stored with passive cooling and 2) to determine storage cell thermal properties and interface and boundary conditions to calibrate and verify thermal models.

The test objectives would be met by a combination of actual test results and calibrated computer model predictions. An encapsulated spent fuel assemoly would be installed into an SSC and the temperatures in the canister, liner and surrounding concrete recorded. In addition, a computer model of the SSC would be prepared for comparison with the test results. The SSC model and an existing fuel rod thermal model would be used to evaluate SSC performance beyond the limits of the test. The maximum canister temperature level attained would be compared with predicted peak canister and peak fuel cladding temperatures to evaluate SSC performance.

Transient test results would be compared to computer code predictions using the thermal power versus time predicted for the actual spent fuel assembly as input. Computer model thermal property and heat transfer correlation revisions would be made as necessary to update the model for good model/test agreement. Good agreement between computer model predictions and test data will qualify the computer model for use in evaluation of storage of various power decay heat level fuel assemblies. 


\subsection{TEST HARDWARE DESCRIPTION}

\section{1 TEST ARRANGEMENT}

The SSC Test hardware arrangement is shown in Figures 1,2 and 3 . The test hardware consists of 1) a carbon steel liner encased in a transportable reinforced concrete shield, 8 feet 8 inches in diameter and 21 feet high, 2) a 16 by 16 feet by 3 feet 10 inches deep reinforced concrete foundation pad, 3) a canister assembly consisting of a canister body, closure lid and a concrete filled shield plug which supports the canister from the top section of the liner, 4) a spent fuel assembly, 5) an array of thermocouple instrumentation to measure temperature response and 6) a data acquisition system to record the thermocouple data. Photographs of the SSC Test hardware and its construction are shown in Figures 4,5 and 6.

\subsection{SSC LINER}

The SSC liner is illustrated in Figure 2 and 3. The liner consists of three sections. The center section of the liner consists of a 17 foot long section of 18 inch diameter by 0.375 inch wall pipe. The upper section of the liner is manufactured from a 34 inch long, 22 inch diameter, 0.75 inch wal1 pipe. The upper and center sections of the liner are positioned concentrically to one another and welded to opposite sides of a 22 inch outside diameter, 17.25 inch inside diameter, 0.50 inch thick ring. This ring forms the ledge on which the 20 inch diameter shield plug (which is connected to the canister assembly) is supported. The lower section is 44 inches in diameter and 14 inches long. This section provides added protection as the cask is transported and contains 7 inches of steel plate and 6 inches of concrete. Welded to the upper section is a tapered entry flange which is notched at two opposite places for routing of canister instrumentation to the SSC external junction boxes. The liner material is carbon steel. 


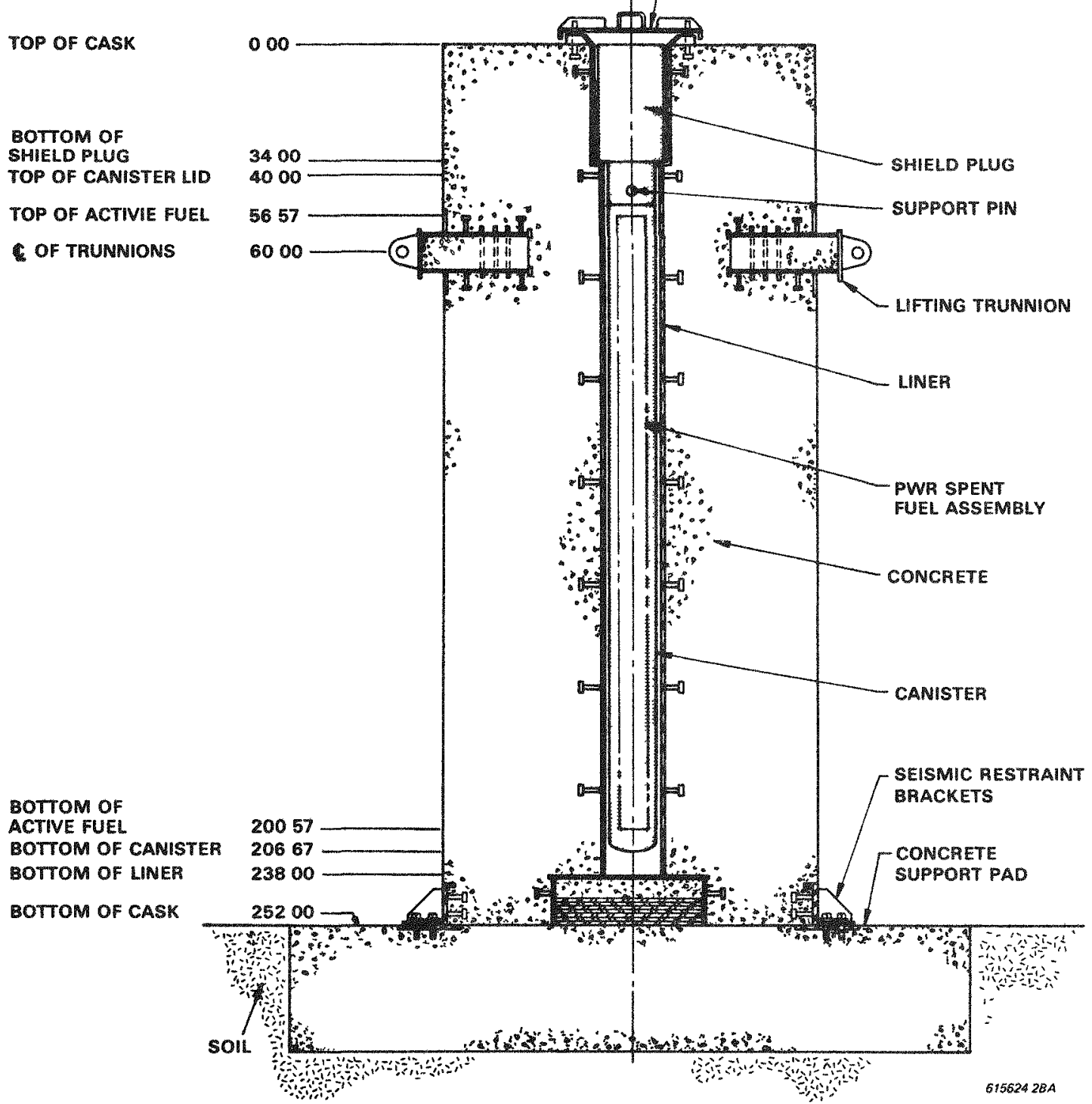

Figure 2. SSC Schematic 


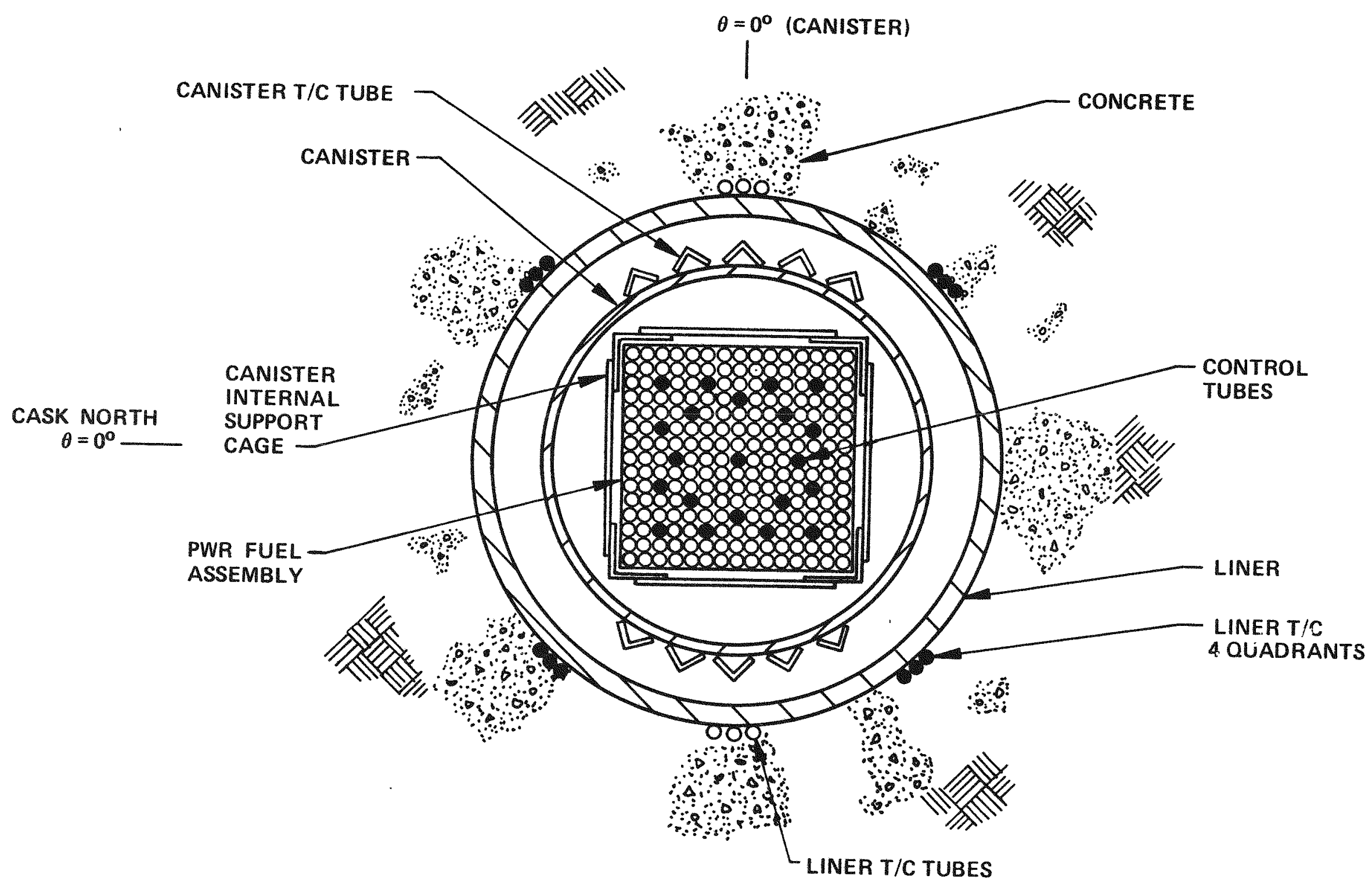

Figure 3. SSC Liner Section View 


\subsubsection{INSTRUMENTATION}

Six tubes, 0.156 inch outside diameter and 0.086 inch inside diameter are attached to the outside of the liner and serve as thermocouple wells. The six tubes extend from the top of the liner to about 2 inches from the lower section of the liner. The tubes are clamped onto the liner by 11 large adjustable band clamps.

The thermocouple tubes are oriented around the liner in two groups as shown in Figures 3. The two groups each contain three tubes that are spaced $180^{\circ}$ apart. The tubes allow thermocouple installation at any elevation. The ends of the tubes are swaged and tackwelded to prevent concrete from filling the tubes during SSC construction. The installed elevation of the thermocouples in the tubes is controlled by the thermocouple length. The thermocouples are inserted until the transition boot between thermocouple and extension lead (see Section 4.7) contacts the top of the tube thus controlling the position of the thermocouple tip. The thermocouples are installed in each group of tubes so that there is one positioned at the middie of the PWR fuel assembly active fuel length, another one foot above the bottom of the active fuel and the other one foot below the top of the active fuel. These thermocouple positions line up with thermocouple positions on the canister. During the construction phase of the SSC, twelve additional thermocouples were attached to the outside of the liner with epoxy cement and banding straps. The thermocouples are oriented around the liner in four equally spaced groups as shown in Figure 3 . The elevations of the thermocouples are the same as described above. Table 1 provides depth and angular position data for the installed liner thermocouples.

\subsubsection{LINER INSTALLATION}

The liner is an integral part of the SSC concrete shield. Four peripheral Nelson studs equally spaced at 8 elevations assure interface integrity with the concrete. The liner is shown in Figure 4 prior to shipment and during placement of surrounding re-inforcing bar in Figures 5 and 6 . 

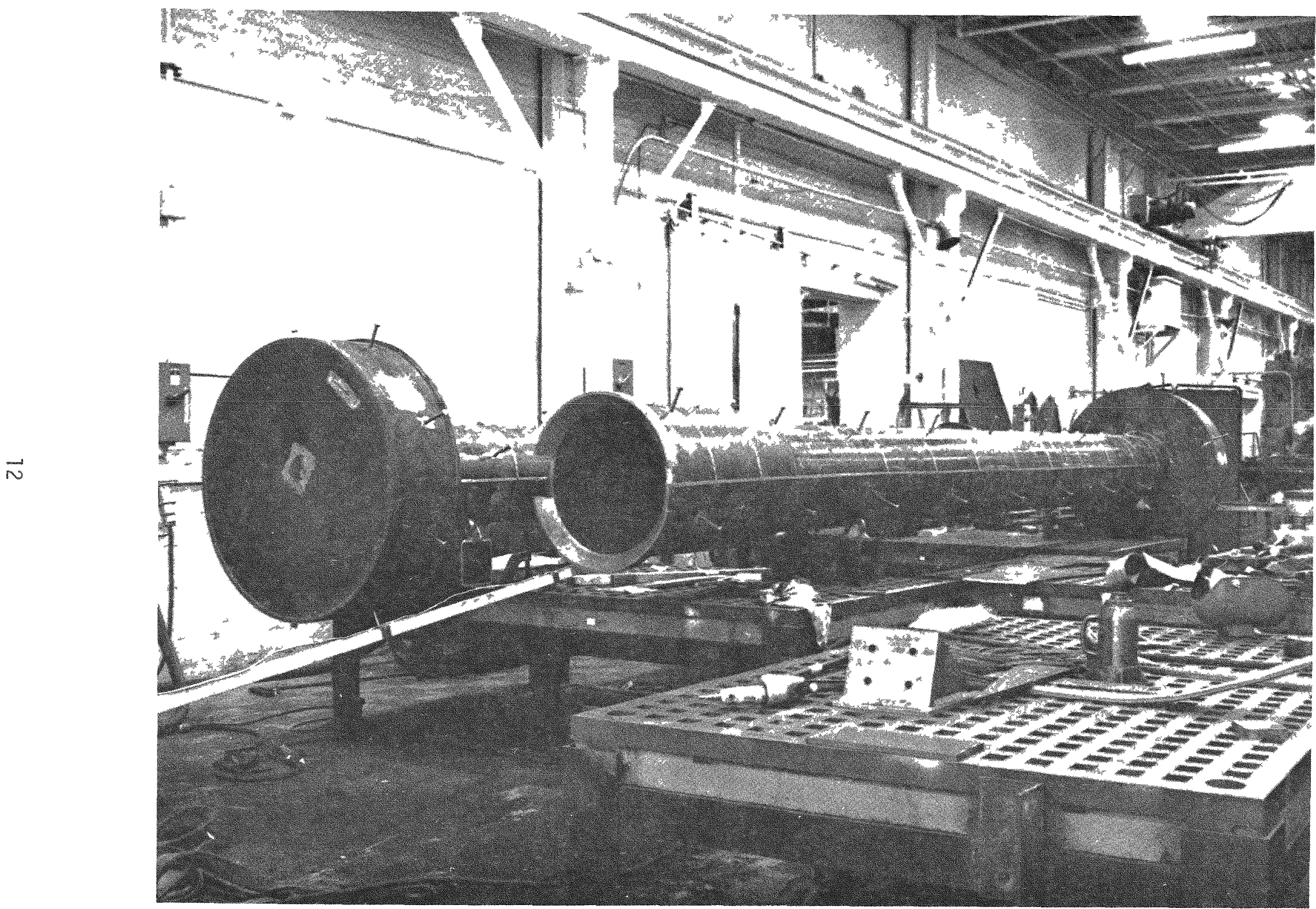

Figure 4. Sealed Storage Cask Liners Prior to Shipping 


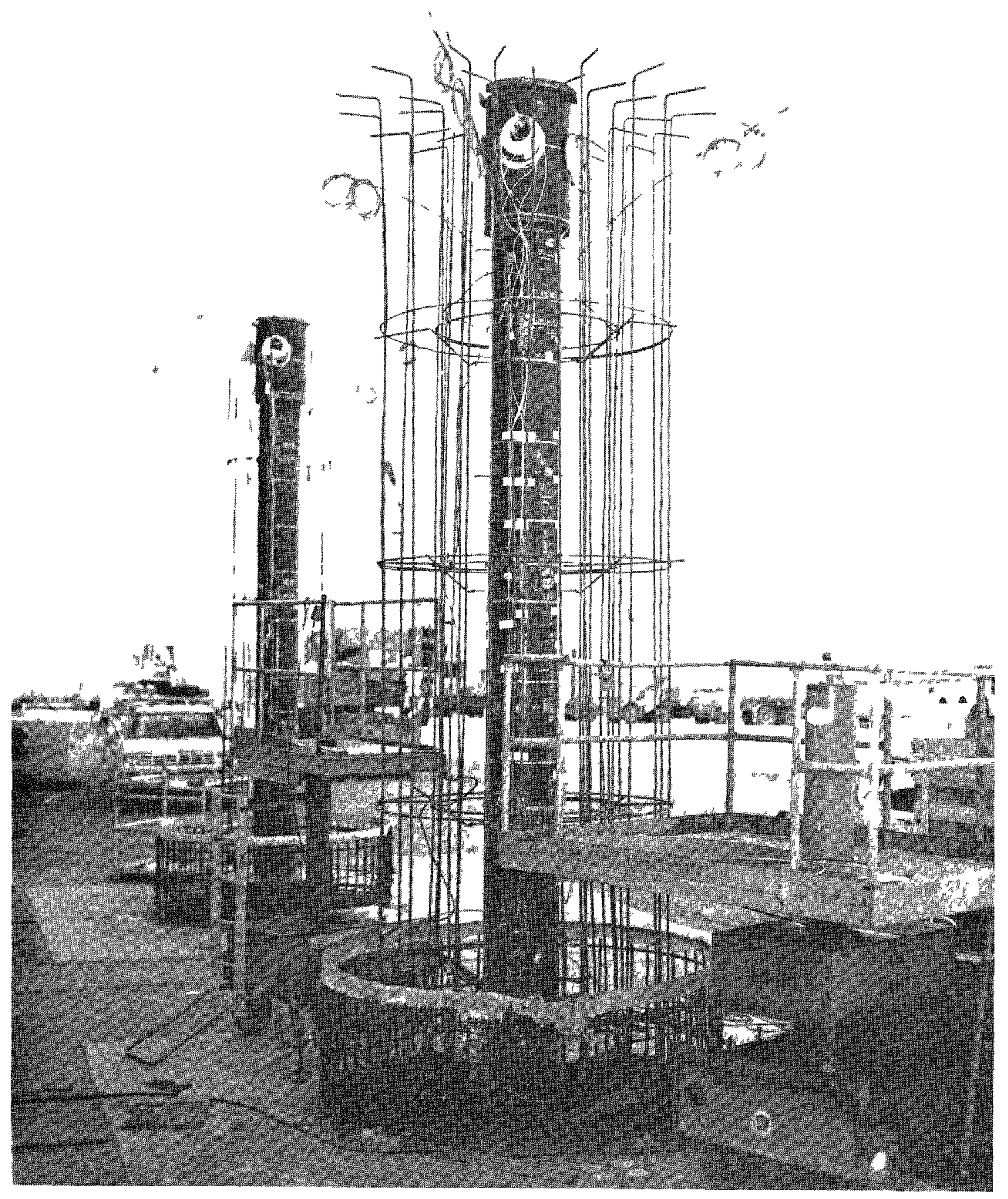

Figure 5. Sealed Storage Cask Liners on Pads During Rebar Installation 


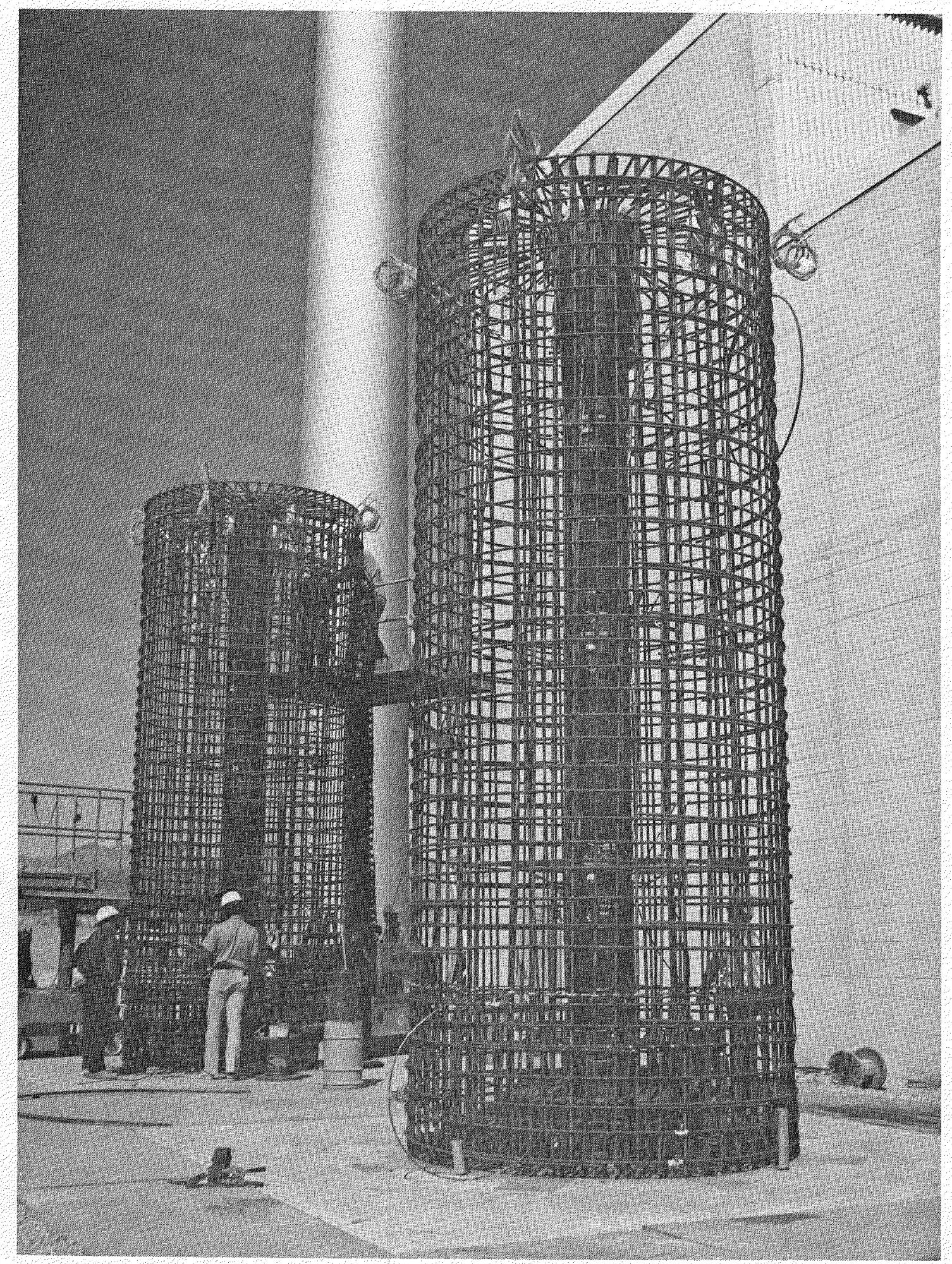

Figure 6. Sealed Storage Cask Rebar Installation Completed Prior to Concrete Pouring 
TABLE 1

SSC-2 THERMOCOUPLE LOCATIONS

\begin{tabular}{|c|c|c|c|c|}
\hline $\begin{array}{l}T / C \\
\text { No. } \\
\end{array}$ & $\begin{array}{c}\text { Distance Below } \\
\text { Top of SSC } \\
(\text { in.) } \\
\end{array}$ & $\begin{array}{l}\text { Radius } \\
\text { (in.) }\end{array}$ & $\begin{array}{l}\text { Orientation* } \\
\text { (Degrees) }\end{array}$ & Location \\
\hline 620 & 68.5 & 9 & 45 & Liner \\
\hline 621 & 68.5 & 23 & 45 & Cask Concrete \\
\hline 622 & 68.5 & 37 & 45 & Cask Concrete \\
\hline 623 & 68.5 & 50 & 45 & Cask Concrete \\
\hline 624 & 128.5 & 9 & 45 & Liner \\
\hline 625 & 128.5 & 23 & 45 & Cask Concrete \\
\hline 626 & 128.5 & 37 & 45 & Cask Concrete \\
\hline 627 & 128.5 & 50 & 45 & Cask Concrete \\
\hline 628 & 188.5 & 9 & 45 & Liner \\
\hline 629 & 188.5 & 23 & 45 & Cask Concrete \\
\hline 630 & 188.5 & 37 & 45 & Cask Concrete \\
\hline 631 & 188.5 & 50 & 45 & Cask Concrete \\
\hline 632 & 68.5 & 9 & 135 & Liner \\
\hline 633 & 68.5 & 23 & 135 & Cask Concrete \\
\hline 634 & 68.5 & 37 & 135 & Cask Concrete \\
\hline 635 & 68.5 & 50 & 135 & Cask Concrete \\
\hline 636 & 128.5 & 9 & 135 & Liner \\
\hline 637 & 128.5 & 23 & 135 & Cask Concrete \\
\hline 638 & 128.5 & 37 & 135 & Cask Concrete \\
\hline 639 & 128.5 & 50 & 135 & Cask Concrete \\
\hline 640 & 188.5 & 9 & 135 & Liner \\
\hline 641 & 188.5 & 23 & 135 & Cask Concrete \\
\hline 642 & 188.5 & 50 & 135 & Cask Concrete \\
\hline
\end{tabular}

*Azimuth orientation is from North $=0^{\circ}$ clockwise 
TABLE 1 (CONTINUED)

SSC-2. THERMOCOUPLE LOCATIONS

\begin{tabular}{|c|c|c|c|c|}
\hline $\begin{array}{l}\text { T/C } \\
\text { No. }\end{array}$ & $\begin{array}{c}\text { Distance Below } \\
\text { Top of SSC } \\
(\text { in.) }\end{array}$ & $\begin{array}{l}\text { Radius } \\
\text { (in.) }\end{array}$ & $\begin{array}{c}\text { Orientation* } \\
\text { (Degrees) }\end{array}$ & Location \\
\hline 643 & 188.5 & 37 & 135 & Cask Concrete \\
\hline 644 & 68.5 & 9 & 225 & Liner \\
\hline 645 & 68.5 & 23 & 225 & Cask Concrete \\
\hline 646 & 68.5 & 37 & 225 & Cask Concrete \\
\hline 647 & 68.5 & 50 & 225 & Cask Concrete \\
\hline 648 & 128.5 & 9 & 225 & Liner \\
\hline 649 & 128.5 & 23 & 225 & Cask Concrete \\
\hline 650 & 128.5 & 37 & 225 & Cask Concrete \\
\hline 651 & 128.5 & 50 & 225 & Cask Concrete \\
\hline 652 & 188.5 & 9 & 225 & Liner \\
\hline 653 & 188.5 & 23 & 225 & Cask Concrete \\
\hline 654 & 188.5 & 37 & 225 & Cask Concrete \\
\hline 655 & 188.5 & 50 & 225 & Cask Concrete \\
\hline 656 & 68.5 & 9 & 315 & Liner \\
\hline 657 & 68.5 & 23 & 315 & Cask Concrete \\
\hline 658 & 68.5 & 37 & 315 & Cask Concrete \\
\hline 659 & 68.5 & 50 & 315 & Cask Concrete \\
\hline 660 & 128.5 & 9 & 315 & Liner \\
\hline 661 & 128.5 & 23 & 315 & Cask Concrete \\
\hline 662 & 128.5 & 37 & 315 & Cask Concrete \\
\hline 663 & 128.5 & 50 & 315 & Cask Concrete \\
\hline 664 & 188.5 & 9 & 315 & Liner \\
\hline 665 & 188.5 & 23 & 315 & Cask Concrete \\
\hline 666 & 188.5 & 37 & 315 & Cask Concrete \\
\hline 667 & 188.5 & 50 & 315 & Cask Concrete \\
\hline
\end{tabular}


TABLE 1 (CONTINUED)

SSC-2 THERMOCOUPLE LOCATIONS

\begin{tabular}{lcccl}
$\begin{array}{c}\text { T/C } \\
\text { No. }\end{array}$ & $\begin{array}{c}\text { Distance Below } \\
\text { Top of SSC } \\
\text { (in.) }\end{array}$ & $\begin{array}{c}\text { Radius } \\
\text { (in.) }\end{array}$ & $\begin{array}{c}\text { } \\
\text { Orientation* } \\
\text { (Degrees) }\end{array}$ & Location \\
\cline { 2 - 3 } 668 & 68.0 & 9 & 270 & Liner \\
669 & 68.0 & 9 & 90 & Liner \\
670 & 128.0 & 9 & 270 & Liner \\
671 & 128.0 & 9 & 90 & Liner \\
672 & 188.0 & 9 & 270 & Liner \\
673 & 188.0 & 9 & 90 & Liner \\
674 & 68.0 & 7 & 240 & Canister \\
675 & 68.0 & 7 & 60 & Canister \\
670 & 98.0 & 7 & 255 & Canister \\
677 & 98.0 & 7 & 75 & Canister \\
678 & 128.0 & 7 & 270 & Canister \\
679 & 128.0 & 7 & 90 & Canister \\
680 & 158.0 & 7 & 285 & Canister \\
681 & 158.0 & 7 & 105 & Canister \\
682 & 188.0 & 7 & 300 & Canister \\
683 & 188.0 & 7 & 120 & Canister
\end{tabular}




\subsection{CANISTER ASSEMBLY}

The canister assembly consists of a canister body, closure lid and a shield plug. An illustration of the details of the canister assembly is shown in Figure 7, an illustration of the closure lid is shown in Figure 8 , and illustrations of the shield plug and its attachment to the canister body are shown in Figures 9 and 10. The canister described below was designed to accommodate one Turkey Point Reactor PWR spent fuel assembly.

\subsubsection{CANISTER BODY}

The main body of a PWR canister is a standard 14 inch outside diameter, 0.375 inch wa11, 154 inches long 304 stainless steel pipe. Welded to the bottom of this pipe is a standard 14 inch diameter, 6.5 inch high ellipsoidal end cap. This end cap has welded into it a cruciform formed of 0.75 inch 304 stainless steel plate. This cruciform supports the bottom of a PWR fuel assembly and acts as a loosely toleranced keyed assembly for the fuel assembly bottom nozzle.

The top of the PWR canister body consists of a section of 14 inch outside diameter, 0.937 inch wall, 304 stainless steel pipe approximately 9 inches long. This section is welded to the 0.375 inch thick main body pipe and contains machined threads which mate with the closure 1id. The outside upper surface of the canister body contains 4 blind holes equally spaced around the pipe circumference for the attachment of the shield plug. Two 0.75 inch square bars (keys) are welded to the outside of the canister body to support the canister during remote operations and to align the shield plug so that instrumentation tubes are in the proper orientation.

Welded to the inside of the PWR canister body is a fuel assembly support cage formed of standard 2.0 inch by 2.0 inch by 0.18 inch thick 304 stainless stee] angles tied together on four sides at six elevations by thin plates. This cage provides lateral support for the entire length of the PWR fuel assembly. 


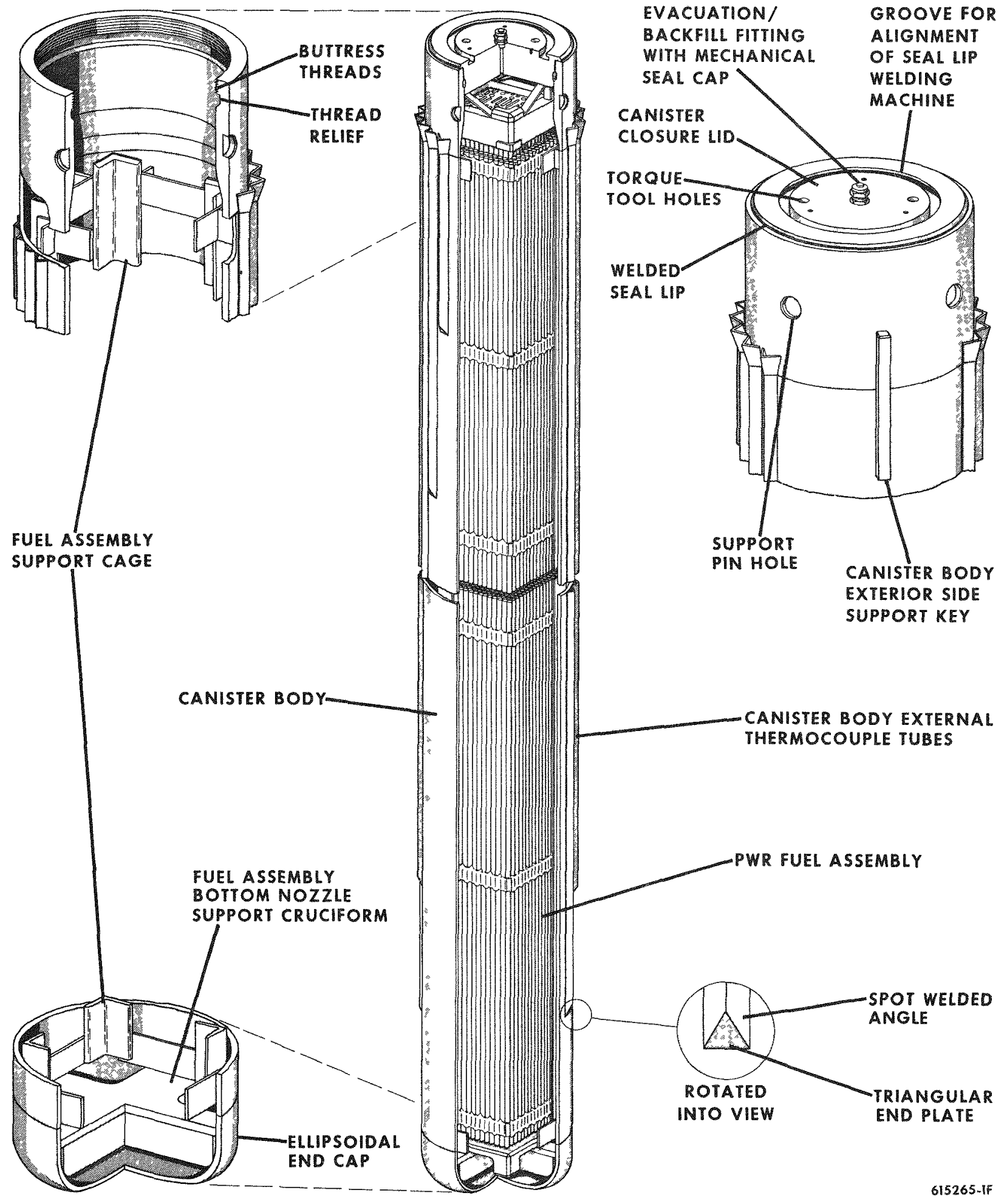

Figure 7. Canister Configuration 


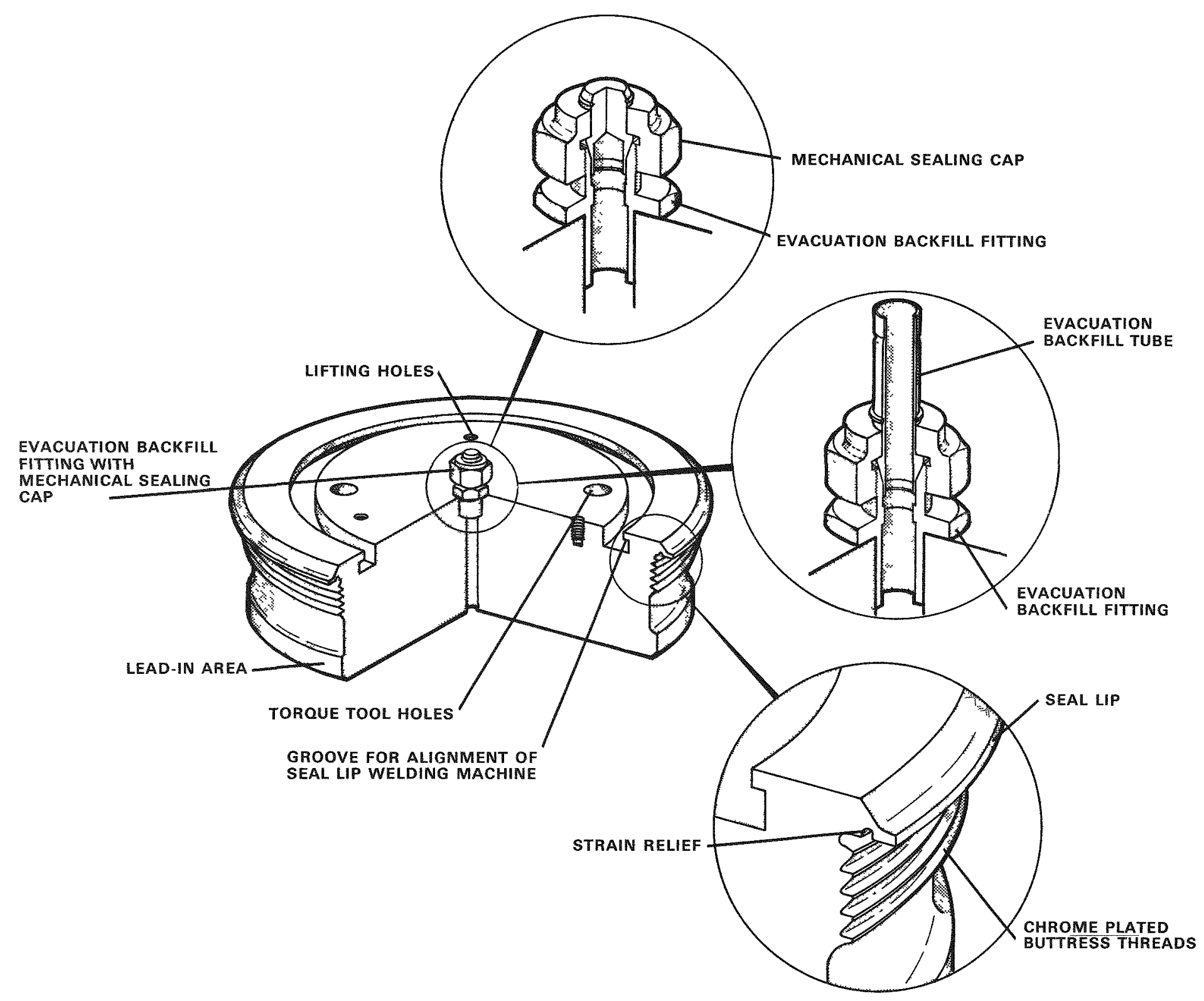

615045-4CA

Figure 8. Canister Closure Lid Configuration 


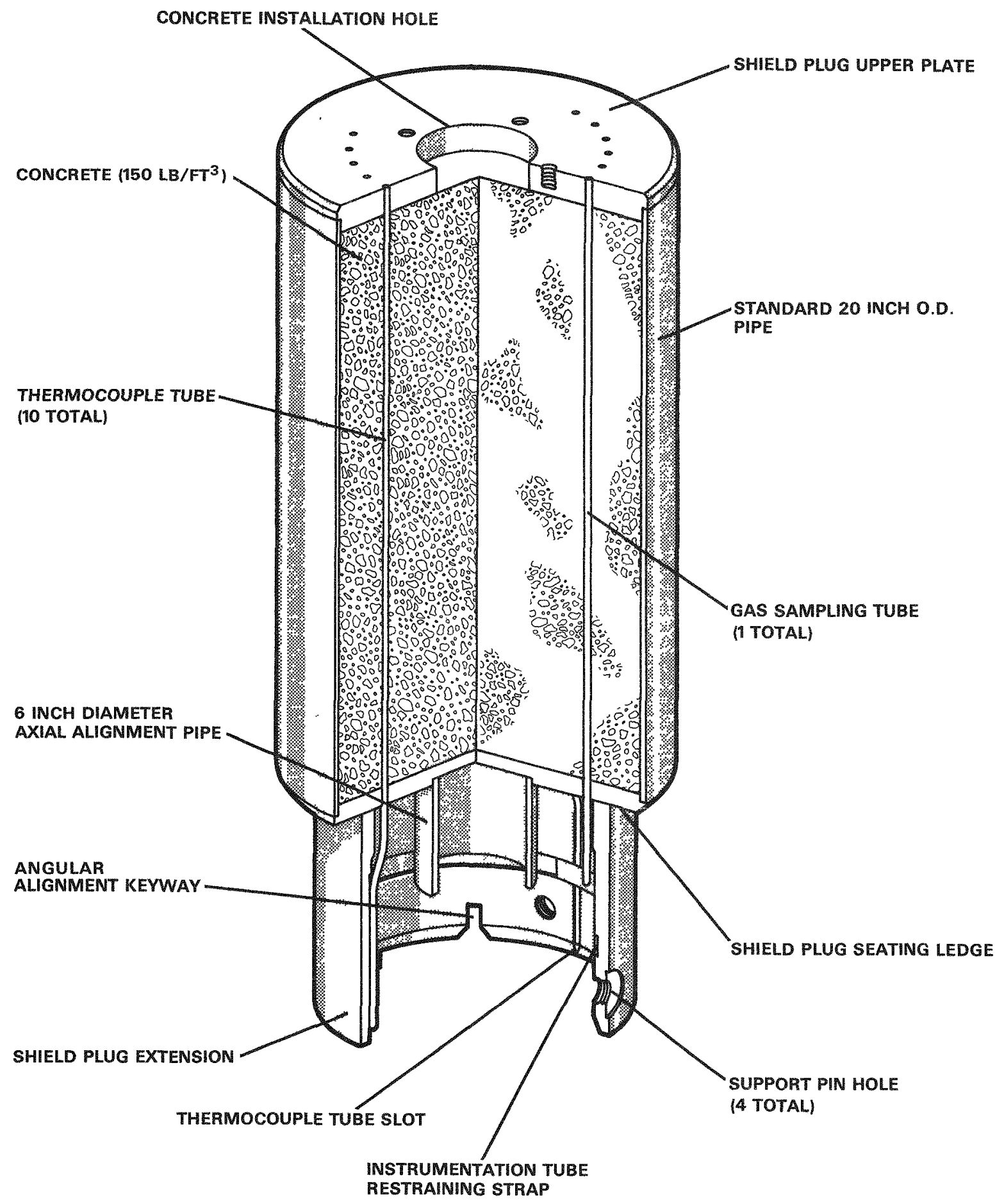

Figure 9. Shield Plug Configuration 


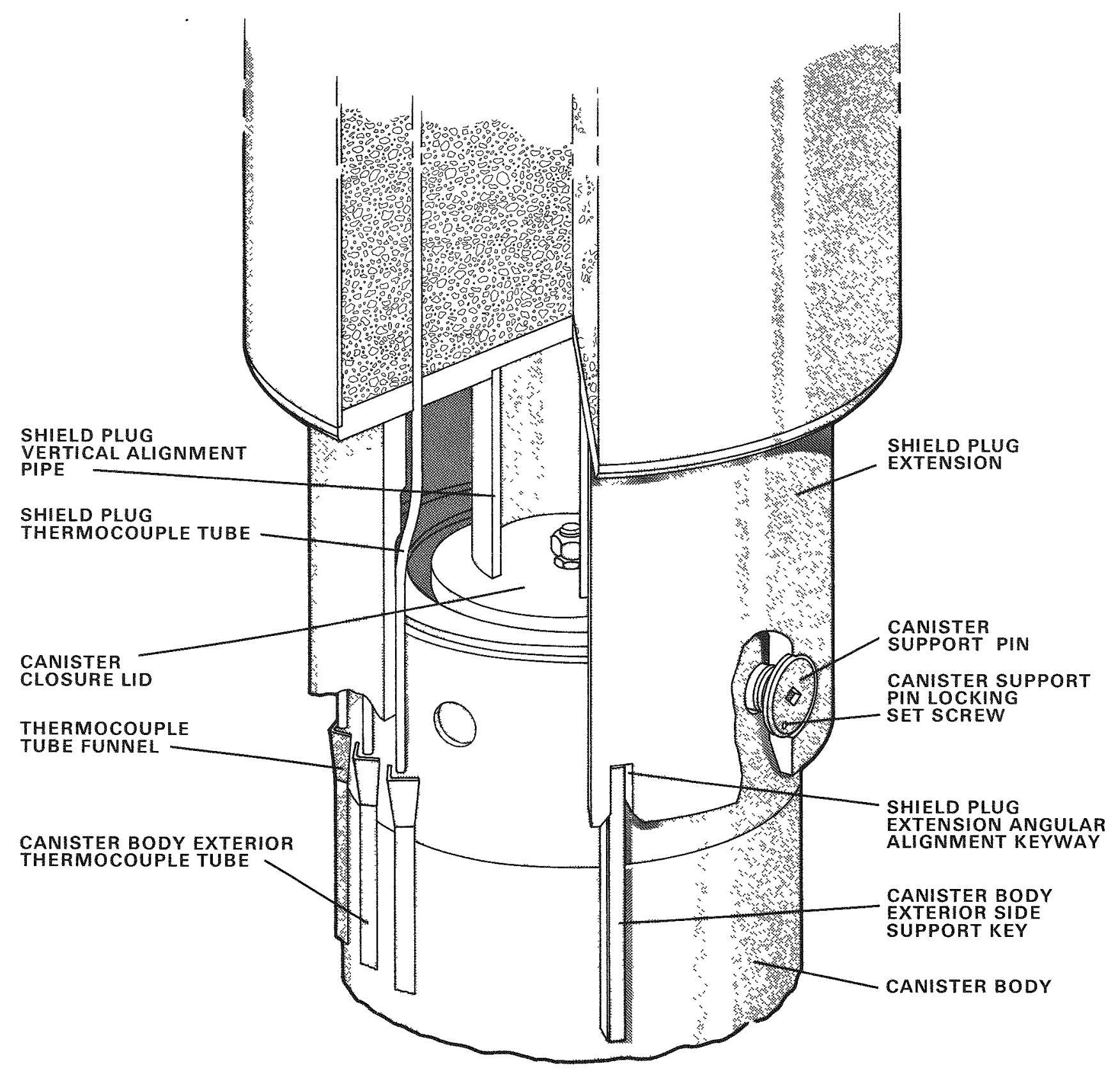

Figure 10. Canister and Concrete Shield Plug Mating 


\subsubsection{INSTRUMENTATION}

The canister contains ten thermocouple tubes for insertion of thermocouples after emplacement in an SSC. The thermocouple tudes consist of inverted 0.75 inch by 0.75 inch by 0.12 inch thick angles tack welded to the outside of the canister body. A funnel is formed at the top of each tube by a 1.25 inch by 1.25 inch angle cut to match the smaller angle and welded to the top of the tubes (see Figure 7). The funnel is provided to allow for potential radial and azimuthal mismatch between shield plug and canister body instrumentation tubes and to assure proper thermocouple installation. An angled triangular plate is welded to the bottom of each tube. It is mounted at a relatively steep angle to promote contact between thermocouple junction and canister wall (see figure 7).

Five thermocouple tubes are located on opposite sides of the canister with the center tubes of each group being $180^{\circ}$ apart. The five tubes in each group are spaced $15^{\circ}$ apart and extend down the canister to lengths matching the PWR fuel assembly active fuel middle, 2.5 feet above and below the active fuel middle and 1.0 foot from each end of the active fuel. The thermocouples are installed through tubes in the shield plug until the transition boot is 6.0 inches above the top of the shield plug.

The thermocouples when installed measure temperatures at five different elevations on both sides of the canister to determine the axial canister temperature profile. The uppermost, middle and lowermost of thermocouples are located at the same elevations as those in the SSC liner. Table 1 identifies the thermocouples installed in the canister and the SSC.

\subsubsection{CLOSURE LID}

The closure lid as shown in Figure 8 is a flat disc, 3.5 inches thick and 12.5 inches in diameter. The disc has approximately 1.0 inch of buttress threads machined near the top which mate with threads machined into the thicker section of 14 inch diameter pipe at the top of the canister body. The top outside surface of the closure lid is machined to form a seal lip for seal 
welding of the canister after the fuel assembly is installed. Features on the top surface of the closure lid include a machined groove for alignment of the seal welding machine with the machine seal lip, provisions for the lifting and torquing fixture, and a fitting with a mechanically sealed cap through which nelium is introduced into the canister. The bottom 1.0 inch of the closure lid serves as a lead-in for the installation of the lid into the canister body.

The seal 1ip on the canister closure lid is welded to the canister body to complete the containment boundary. The gas fitting on top of the closure lid is used to evacuate the canister and backfill with helium. The helium serves to provide an indicator for initial leak checking of the closure lid seal weld and the gas fitting mechanical seal, to stabilize the fuel assembly in an inert atmosphere, and to ennance conductive heat transfer to the canister.

\subsubsection{SHIELD PLUG}

The canister is attacned to a shield plug before emplacement into storage. The shield plug shown in Figure 9 is a 20 inch outside diameter, 0.25 inch wall carbon steel pipe approximately 34 inches long with a 1.0 inch thick plate welded to the top and bottom. The volume between the two end plates is filled with concrete for shielding. Extending from the bottom plate of the assembly is a 16 inch outside diameter, 1.031 inch wa11, carbon steel pipe approximately 13.5 inches long. This pipe extension contains 4 tapped noles $90^{\circ}$ apart which accept the canister support pins. It is through these pins that the canister is secured to the shield plug. The shield plug is lowered over the canister body (which fits inside of the 16 inch diameter extension) and the support pins are threaded into the shield plug extension as shown in Figure 10. The pins protrude from the inside of the extension into 4 flat-bottom holes in the upper portion of the canister.

The shield plug has eleven 0.086 inch inside diameter tubes which extend from the upper plate, through the lower plate down to the bottom of the shield plug extension, 10 for routing thermocouples to the canister and one for sampling the atmosphere above the canister lid. The ten thermocouple tubes are routed 
through slots in the bottom portion of the extension so as not to interfere with canister body. The tubes are secured to the extension by spot welded straps. The shield plug has two sets of 5 tubes with $15^{\circ}$ spacing between tubes. The tubes are oriented with respect to the thermocouple tubes on the canister by an alignment keyway in the shield plug extension and a bar (key) on the outside of the canister.

\subsection{PWR SPENT FUEL ASSEMBLY}

The specific spent fuel assemblies selected for the SFHPP 1978 Demonstration were four spent PWR fuel assemblies from the Turkey Point Reactor located in Southern Florida. A representative Turkey Point fuel assembly is shown schematically in Figure 11. The selected assemblies are 161.3 inches long (prior to irradiation) with a square cross section having a maximum distance across flats of 8.47 inches. The overall length is made up of a top nozzle, the fuel rods, and the bottom nozzle. The 204 fuel rods and 21 control tubes are arranged in a $15 \times 15$ array as shown in Figure 3 . The fuel rods are 0.422 inch diameter zircaloy cladding around $\mathrm{UO}_{2}$ pellets with a square pitch of 0.563 inches. The active fuel length is 144 inches. The fuel rods are laterally constrained by a series of 7 grids located along the length of the rods. The PWR fuel assemblies are supported by the bottom nozzle when in the vertical position. The bottom nozzle has four square feet located at the corners of the assembly. These feet interface with the cruciform in the bottom of the canister. A PWR fuel assembly weighs approximately 1500 pounds.

The specific PWR fuel assemblies were chosen based on their burnup (25,000 MWD/ MTU) and their decay time (time out of reactor). Initial model predictions indicated that maximum decay heat levels for spent fuel should be limited to less than $1.25 \mathrm{~kW}$. The four Turkey Point fuel assemblies (Serial Numbers B02, B03, B41, and B43) were chosen based on an estimated decay heat level slightly less than $1.25 \mathrm{~kW}$ at the earliest SSC emplacement date (November 1978). This decay heat level was based on the predicted decay heat curve (Figure 12) and the October 1975 discharge date for the four assemblies. Specif ic data (operating statistics, dimensional measurements, weight data, flux and gamma 


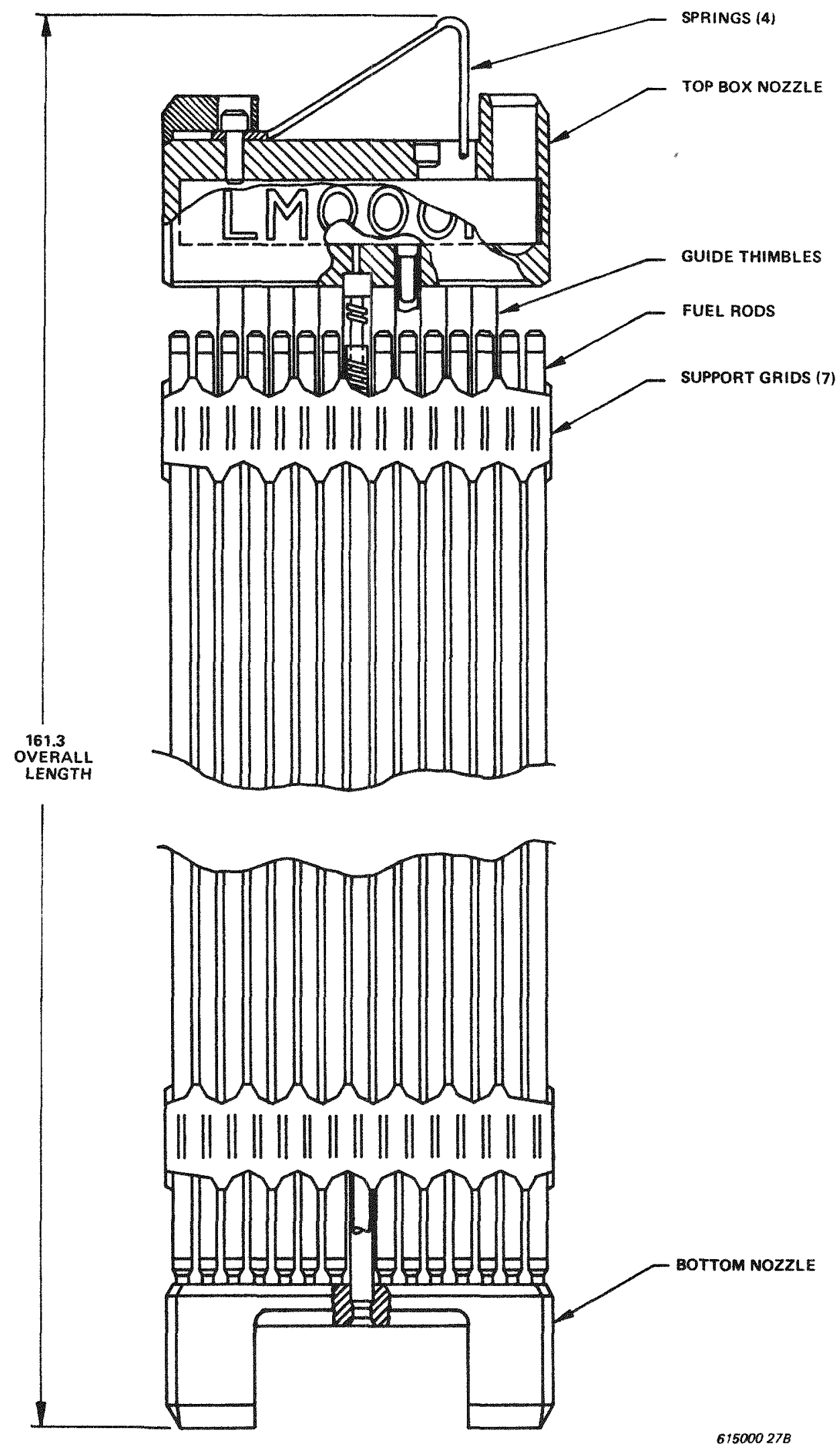

Figure 11. PWR Fuel Assembly Configuration 


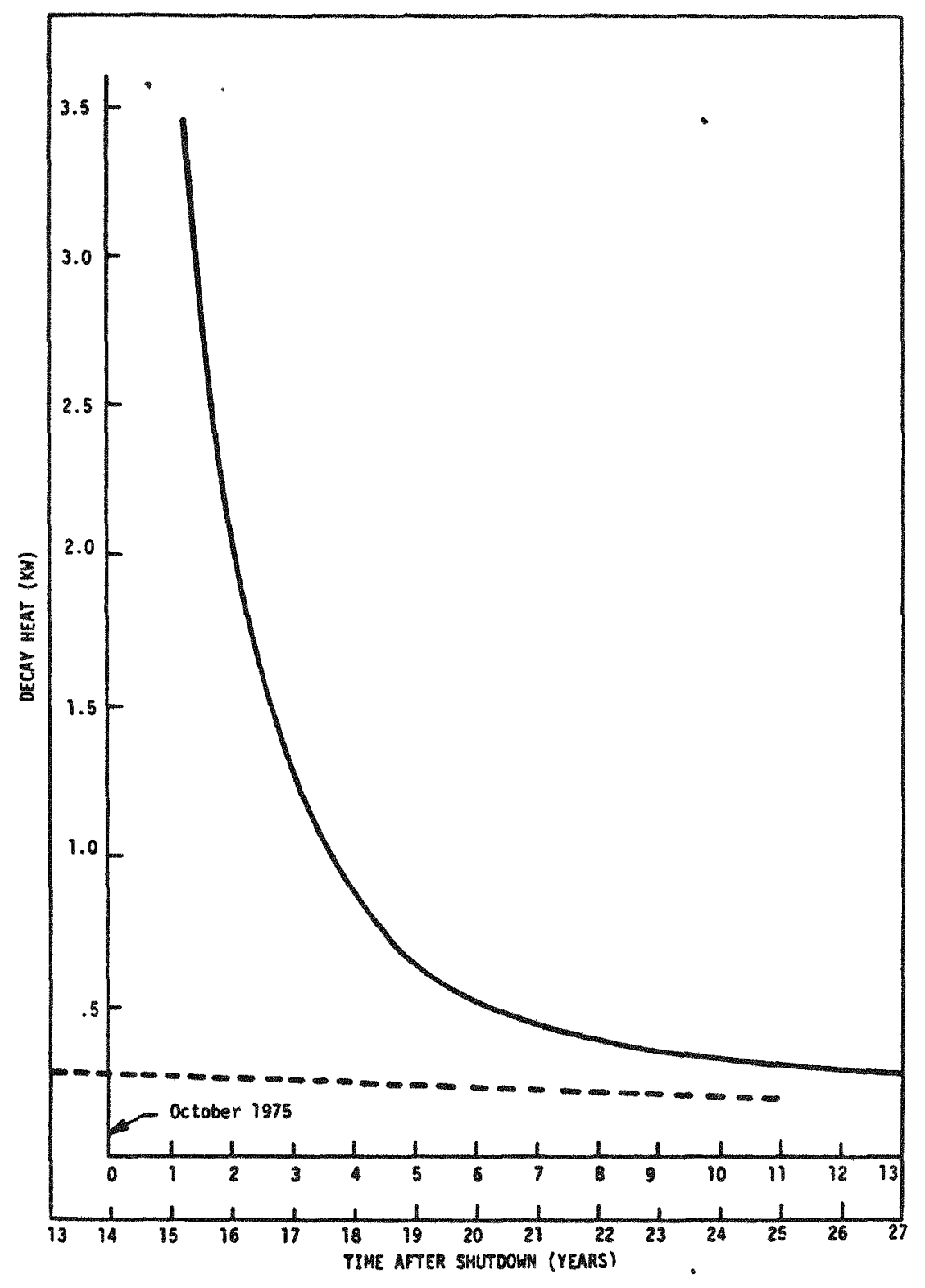

Figure 12. Predicted Decay Heat After Shutdown for Turkey Point PWR Spent Fuel Assemblies 
scan data, etc.) concerning the spent fuel assemblies was collected prior to their shipment to E-MAD and is reported in Reference 3. Figure 13 shows a spent fuel assembly being lowered into a canister.

\subsection{STORAGE SITE}

The storage site for the two SSC's is located on the west side of the E-MAD building within the security fenced area surrounding the E-MAD complex as shown in Figure 14. The area west of the E-MAD building was chosen as the storage site since it is fairly level and would require a minimum of site modifications.

The site was prepared by excavating a 20 by 46 foot hole to a depth of 9 feet. The hole was then filled to a depth of 6 feet with lean concrete. Two 16 by 16 by 3 foot reinforced concrete foundation pads were then constructed on this subfoundation. The SSC storage area construction (shown in Figures 15 and 16) was completed in September, 1978. The storage area concrete pads were emplaced 26 feet apart for two SSC's. The first SSC (\#2) is placed 27 feet south and 22 feet east of the NE corner of E-MAD. This location was selected to permit access for the SSC transporter and mobile crane. Eight embedment plates in the pad are utilized to permit bolting the SSC to the pad.

Underground conduit was laid to allow for instrumentation routing for the two casks. Four lines of 2 inch diameter PVC pipe were installed approximately 2 feet below ground level running from the instrumentation shed to an enclosure between the casks. Vertical sections of steel pipe were installed at the end of each pipe to attach the large waterproof, dustproof electrical enclosure. The instrumentation conduit is connected to an environmentally controlled instrumentation shed located outside the E-MAD building. Flexible conduit routed the instrumentation from the large enclosure to junction boxes mounted on the casks. 


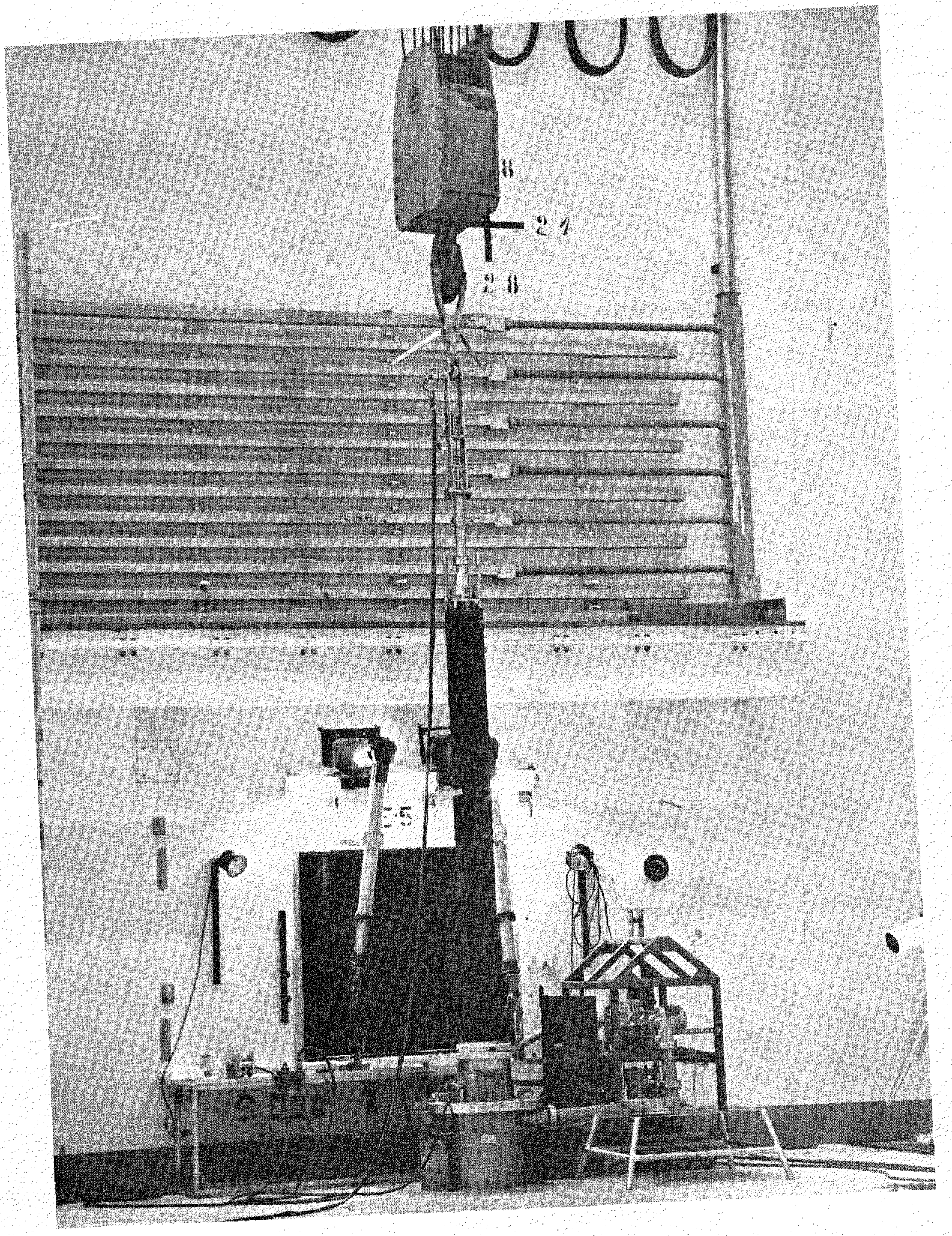

Figure 13. PWR Fuel Assembly Being Installed Into Canister 


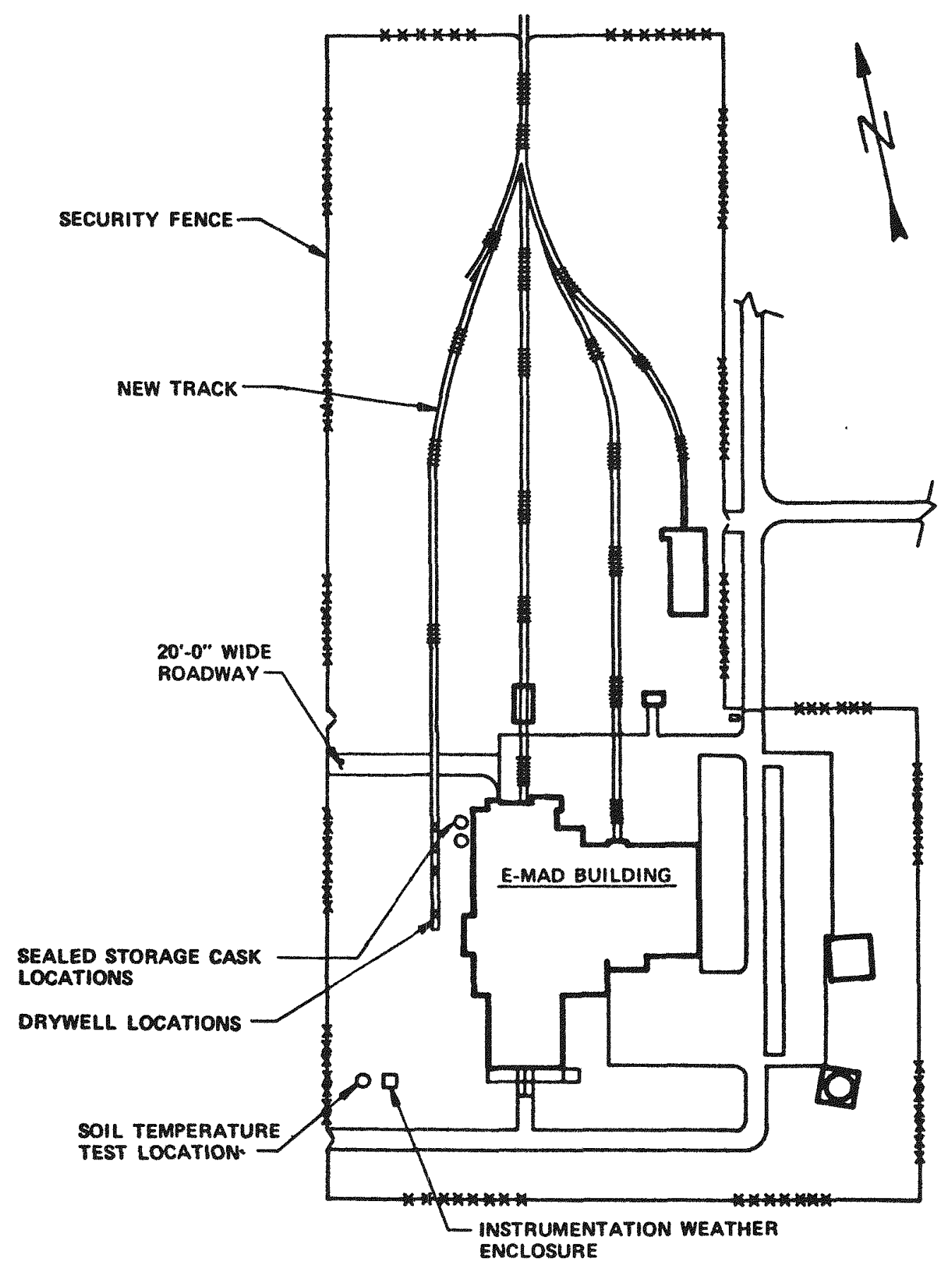

Figure 14. E-MAD Storage Site Configuration 


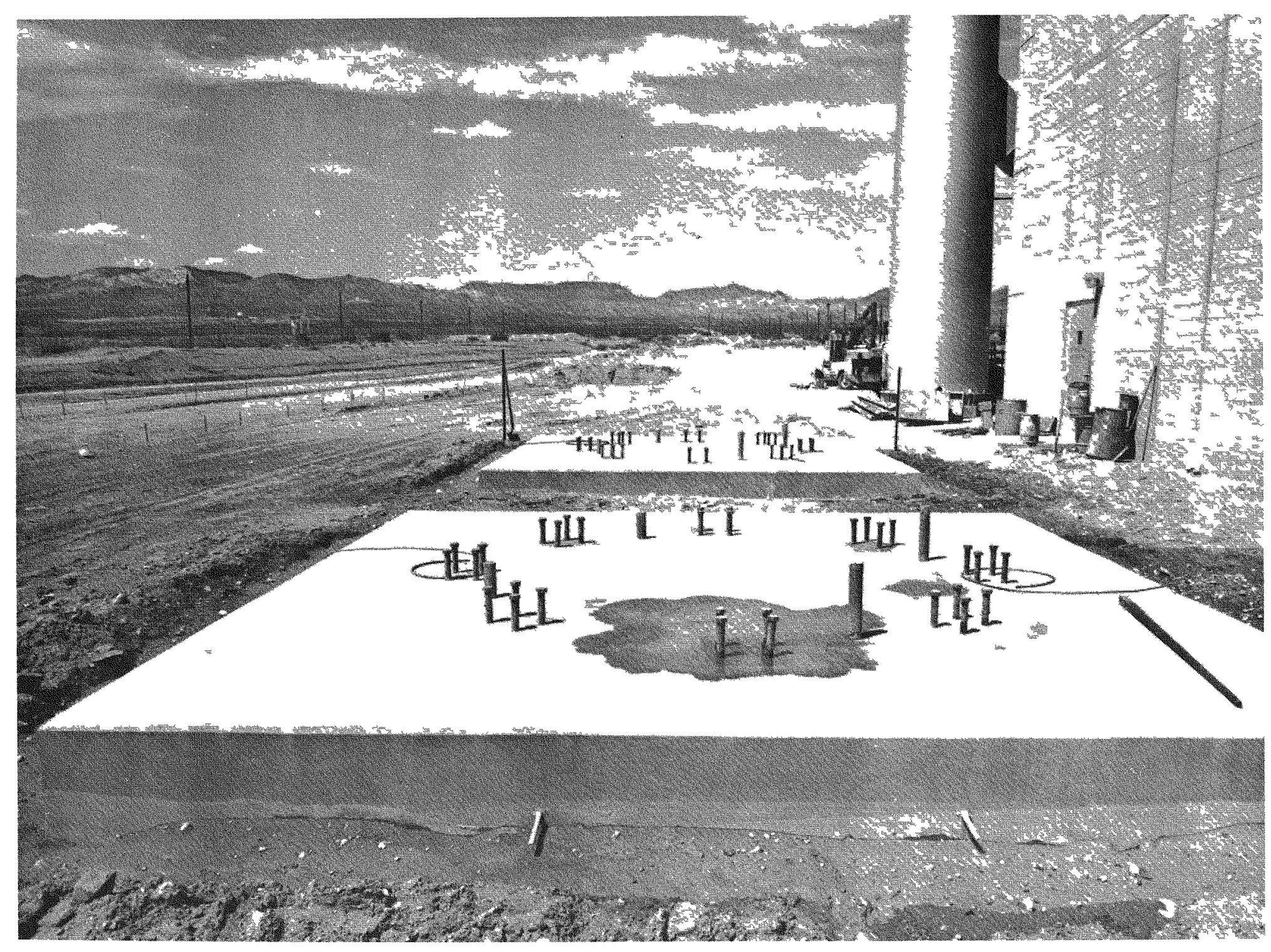

Figure 15. Sealed Storage Cask Foundation 


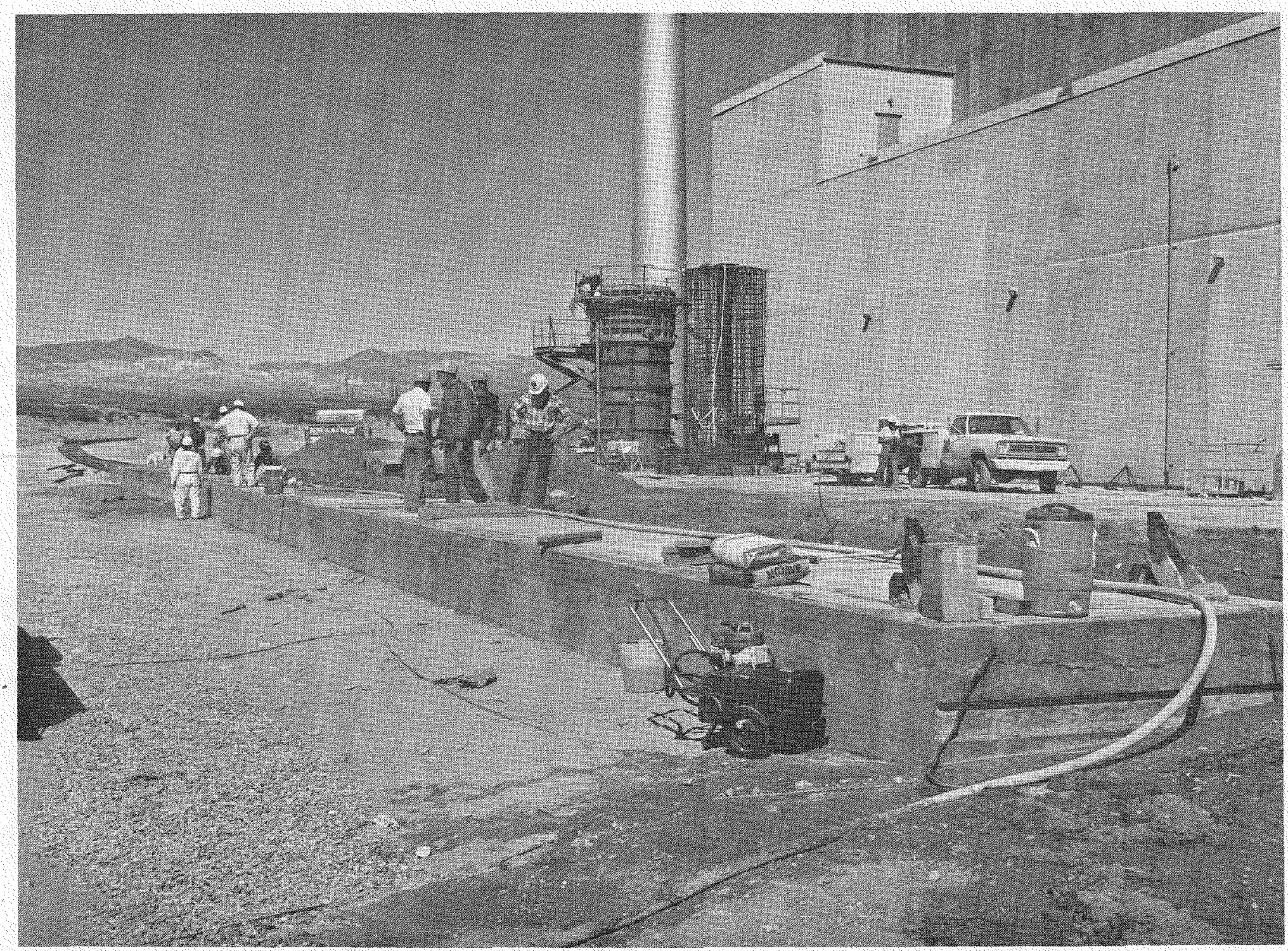

Figure 16. SSC and Drywel1 Storage Area Construction 


\subsection{SEALED STORAGE CASK ASSEMBLY}

\subsubsection{SSC CONSTRUCTION}

The SSC is a reinforced concrete shielded container constructed on its

foundation pad as shown in Figures 5, 6 and 16 . The finished size is 252 inches high and 104 inches in diameter. Three rings of reinforcing bar surround the liner. The outer ring at a 50 inch radius has 0.75 inch diameter bars placed vertically and circumferentially on 6 inch centers. At the top and bottom of the cask there are formed radial extensions between the liner and outer ring. The two inner rings at radii 23 and 37 inches have 12 symmetrically placed vertical bars 0.625 inch in diameter, and 3 hoops 0.5 inch in diameter. The purpose of these rings is to position and support the thermocouples that extend down from the top of the cask.

Embedded within the periphery of the outer reinforcing ring are four handling trunnions of which only two are required to handle the assembled cask weight of approximately 95 tons. The trunnions are fabricated from 10 inch $\mathrm{SCH} .140$ pipe, capped at the outer end and filled with grout. The pipe is 30 inches long and extends 6 inches past the cask surface. Welded to the pipe at this interface is a 24 inch square by 0.75 inch thick plate. Also welded to the embedded portion of the pipe are three 15 inch diameter rings on 4 inch centers. Twenty Nelson studs welded to the plate and pipe periphery assure interface integrity with the concrete.

At the base of the cask are eight welded brackets embedded in the SSC by $8 \mathrm{Nelson}$ studs. The brackets are bolted to embedments in the foundation pad. The vertical plate of the bracket is 12 inches by 20 inches long by 0.75 inch thick rolled to a 52 inch outside radius. The horizontal plate is 12.5 inches wide by 18 inches long by 0.75 inch thick. Three 0.75 thick gusset plates are welded to the two plates. This method of attaching the cask to the pad prevents cask overturning from a horizontal seismic loading of $0.25 \mathrm{~g}$. 
Following the assembly of the reinforcing bar, thermocouples, trunnions and brackets, a circular concrete form is placed around the structure and the concrete placement is completed in a single continuous pour.

Other components of the SSC are a cask cover and a special handling sling. The cask cover plate with a neoprene gasket is bolted to the top of the cask to seal the interior. The cover is 38 inches in diameter by 0.5 inch thick steel plate. Six radial ribs, 2.0 inch high, strengthen the plate. The plate is attached by six 0.5 inch concrete anchor studs. The handling sling for the SSC has a rated capacity of 110 tons. The sling has two legs approximately 23 feet 1ong. Each sling leg is a two part 2.25 inch diameter wire rope equalizing strand-7aid grommet construction sling of improved plow steel. The endless strand has equalizing thimbles at both ends. The two legs are attached to a pear ring with a 137.5 ton minimum rating. A 10 inch SCH. 60 pipe spreads the two legs 9 feet apart about 8 feet above the bottom of the legs.

\subsubsection{INSTRUMENTATION}

The temperature characteristics of the SSC are measured using thermocouples located throughout the SSC. In addition to instrumentation described in Section 4.2 and 4.3 for the liner and canister, an additional 36 thermocouples are embedded in the concrete. This instrumentation has compass azimuthal orientations of $45^{\circ}, 135^{\circ}, 225^{\circ}$, and $315^{\circ}$ and is at elevations of 68,128 and 188 inches measured from the top of the cask. Instrumentation embedded in the concrete have radii of 23,37 and 50 inches. Four equally spaced pull boxes are located near the top periphery of the cask for collection of the thermocouple lead wires from each cask quadrant. The thermocouple lead wires are then routed through rigid conduit to a second set of terminal boxes located on the outer surface of the cask below the pull boxes. Each thermocouple terminal box contains a special chromel and alumel terminal connector for termination of the thermocouples.

After the cask unit has been loaded with a canister assembly and moved to the storage site, flexible conduit route the lead wires from the 36 thermocouples 
embedded in the concrete from the terminal boxes to the storage site junction box (Section 4.5). The lead wires from the ten canister thermocouples and six liner thermocouples, contained in thermocouple tubes, are routed through another flexible conduit directly to the storage site junction box. All conduit and junction box fittings are sealed for water tightness.

\subsubsection{CANISTER INSTALLATION}

The encapsulated fueled canister is installed into the SSC in the E-MAD Hot Bay as shown in Figure 17. The SSC is transported to the Hot Bay on a low bed trailer. A 135 ton capacity mobile crane with the SSC handling sling, shown in Figure 18, is used to load the SSC onto the trailer.

\subsubsection{SSC EMPLACEMENT}

At the SSC storage site the handling sling is attached to two SSC trunnions and the SSC is off loaded onto the storage pad. Four installation guide pins threaded into the pad bracket embedments guide the SSC during the final 16 inches onto the pad. Preparing the SSC for testing includes the following:

1. The guide pins and slings are removed.

2. The SSC is bolted to the foundation pad embedments.

3. The SSC lightning arrestor is connected to the E-MAD grounding grid.

4. The 10 canister and 6 liner thermocouples are inserted into the thermocouple tubes.

5. The thermocouple lead wires are connected as described in Section 4.6.2.

6. The two slots for passage of canister and liner thermocouple lead wires at the top of the cask are filled with RTV silicon rubber.

7. The cask cover plate is bolted to the SSC concrete. 


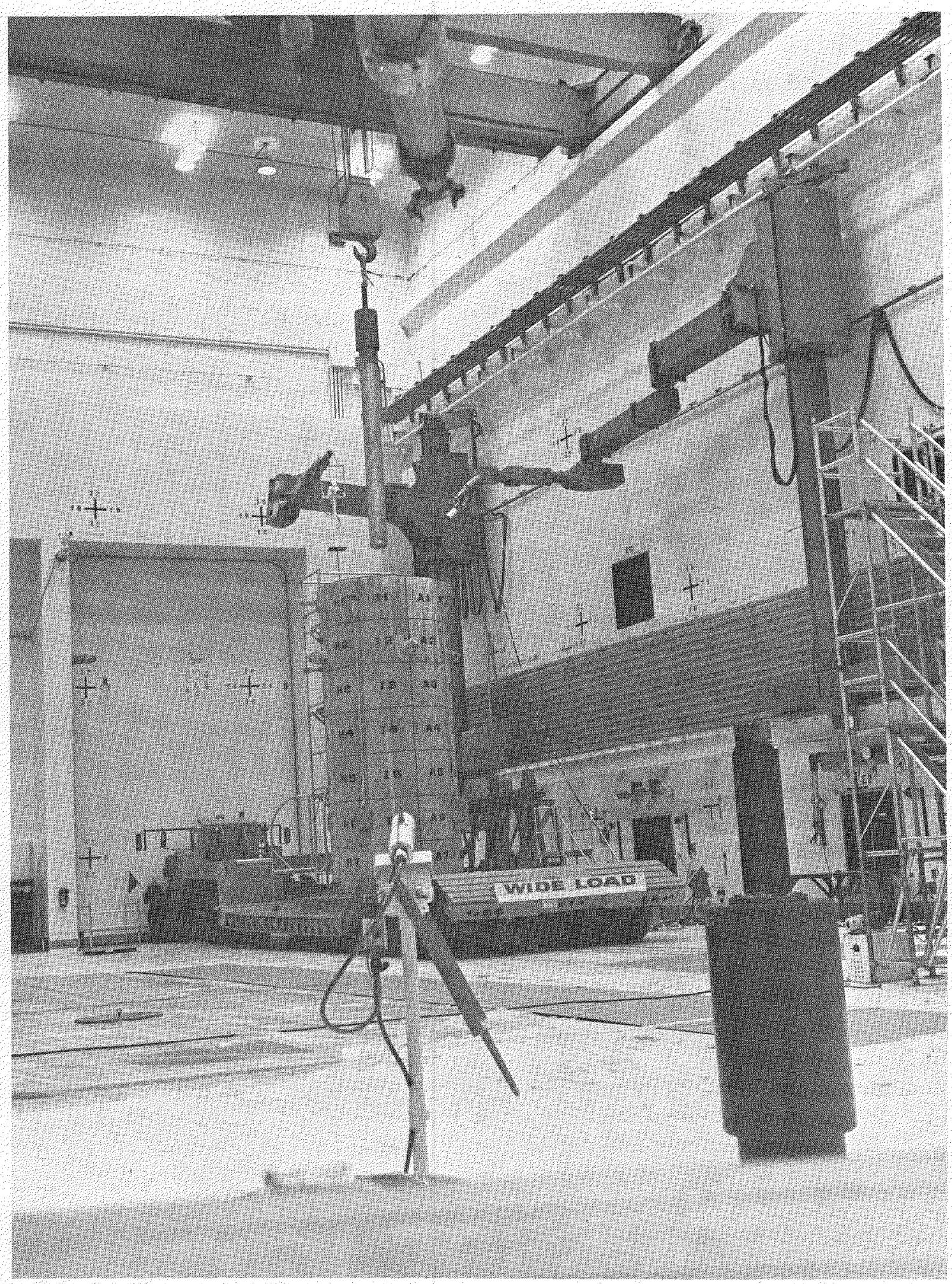

Figure 17. Completed Canister Being Remotely Lowered Into Sealed Storage Cask in Hot Bay 


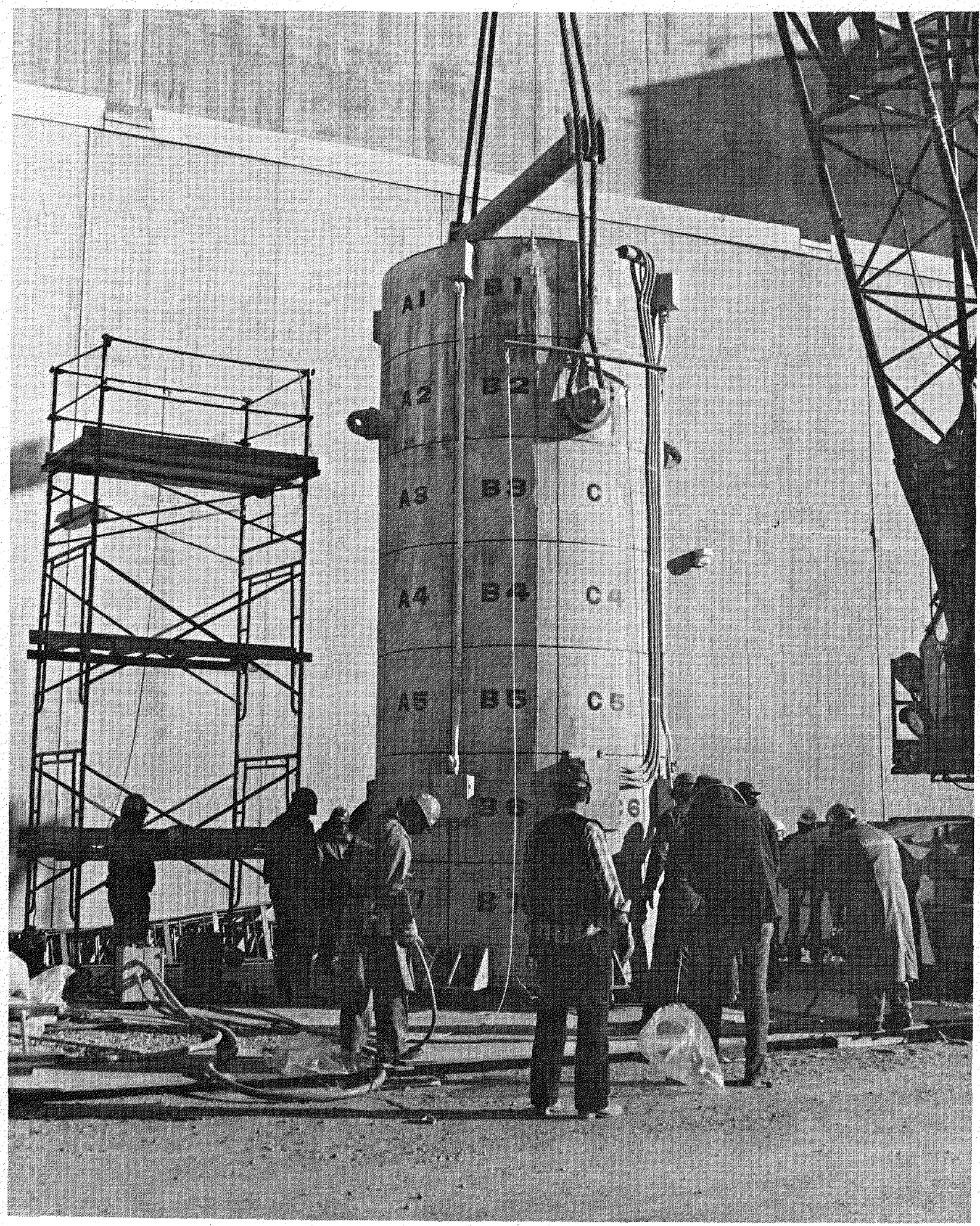

Figure 18. Sealed Storage Cask with Canister Being Lowered Onto Storage Pad 


\subsection{DATA ACQUISITION SYSTEM}

The data acquisition system for the SSC test consists of the array of thermocouples, a data logger, and one remote scanning/multiplexing unit. The thermocouples are attached to the test hardware and the lead wires terminated at the storage site junction box as described earlier in this section of the report. From the storage site junction box the thermocouple leads are routed through rigid underground conduit to the multiplexer unit located in the instrumentation shed outside the E-MAD West Wal1. Multiplexer signal cables are routed through underground conduit to the data logger which is located inside the E-MAD building in the West Operator Gallery.

\subsubsection{THERMOCOUPLES}

A11 thermocouples used in the SSC test described in the preceding sections consist of Type K, chromel-alumel thermocouple with ungrounded junction enclosed in a 304 stainless steel sheath with magnesium oxide insulation. The 48 thermocouples embedded in the concrete have a 0.187 inch diameter sheath with two 22 gauge Type $K$ extension wires brazed to the thermocouple wires. The wires are enclosed in a 0.250 inch diameter by 0.028 wall by 2.75 inches long stainless steel transition boot which is crimped onto the end of the thermocouple sheath and filled with epoxy. The 16 thermocouples for the canister and liner thermocouple tubes are of similar construction and have 0.062 inch diameter sheaths and 24 gauge extension wires. The transition boot is 0.187 inch diameter by 0.010 wall by 2.75 inches long.

\subsubsection{DATA LOGGER SYSTEM}

An Acurex Autodata IX data logger with one remote scanning/multiplexing unit is used for the SSC Test. The data logger is shown in Figure 19 in its installed configuration. The data logger is also used for other experiments at E-MAD and for monitoring spent fuel temperatures within the E-MAD hot cells. The data logger operates on 120 volt, $60 \mathrm{~Hz}$ AC electrical power and is rated for operation in the range of $32^{\circ} \mathrm{F}$ to $110^{\circ} \mathrm{F}$ and 0 to 90 percent relative humidity. This data logger system was selected with capabilities to meet the test needs 


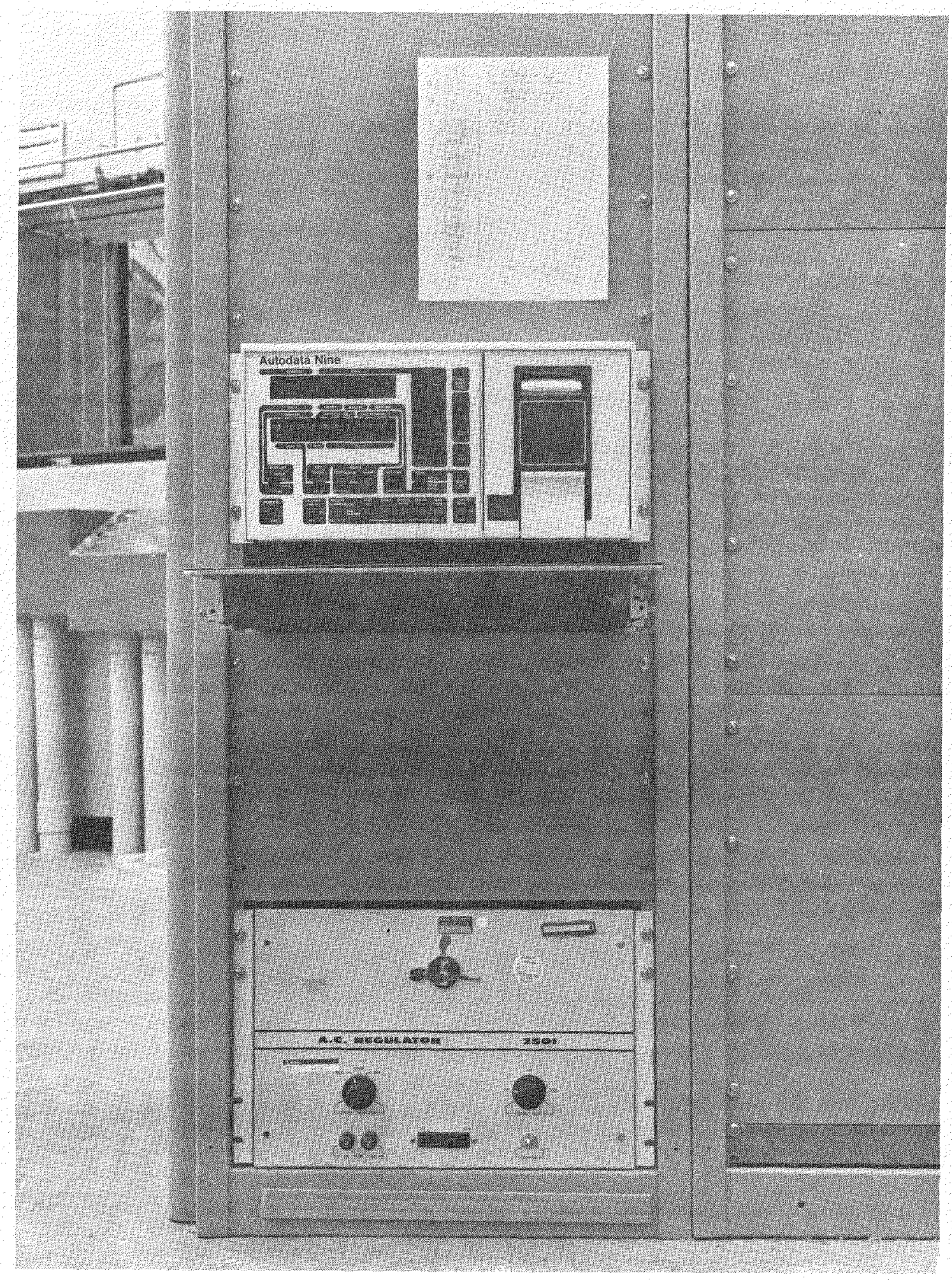

Figure 19. Data Logger Installation in West Gallery 
of the SFHPP 1978 Demonstration with considerations for future expansion. Some of the capabilities being utilized for the SSC Test are as follows:

1. Measurement of Type $K$ thermocouple temperatures from up to 1000 thermocouples.

2. Thermocouple open detection circuit (to determine failures).

3. Remote signal conditioning and multiplexing for remote instrumentation up to 5000 feet from data logger mainframe.

4. Console digital readout in identified engineering units (selectable on the front panel).

5. Printer for output data with header and engineering unit identification.

6. Variable scan modes (single, continuous, and intervals) with adjustable scan intervals.

7. High performance analog to digital conversion. 


\subsection{TEST OPERATIONS AND RESULTS}

\subsection{TEST OPERATIONS}

The initial plan for the SFHPP 1978 Demonstration Storage Cell experiments was to place one canister containing one PWR fuel in one SSC and a second canister containing two BWR fuel assemblies in the other SSC. Delays in procurement of BWR fuel assemblies prevented their encapsulation for use in SSC testing.

Spent fuel assembly encapsulation operations for SSC emplacement occurred during the first week of December, 1978. The spent fuel canister was installed in SSC Number 2 on December 7, 1978. Thermocouples were installed for this canister and all thermocouple leads were routed to the multiplxer unit in the instrumentation shed. Temperature data from SSC \#2 has been monitored from the date of emplacement. Appendix A provides typical mid month data logger printouts of the thermocouple readings. Table 1 provides a listing of thermocouple positions and data logger data channels used to print out the temperature data.

\subsection{TEST RESULTS}

SSC temperature readings are shown in Figures 20 to 26 . In Figure 20 , the thermocouple readings of the peak canister and liner temperature are plotted on a weekly interval through March, 1980. The maximum canister temperature $\left(201^{\circ} \mathrm{F}\right)$ and liner temperature $\left(141^{\circ} \mathrm{F}\right)$ occurred in July, 1979. The cask heatup transient ended after 10 days into the test. Also plotted are the difference in temperature between the canister and liner and between liner and concrete at 23 inches radius. After a year of operation the temperature difference of the canister/liner declined from $75^{\circ} \mathrm{F}$ to $59^{\circ} \mathrm{F}$ and the liner/concrete declined from $25^{\circ} \mathrm{F}$ to $19^{\circ} \mathrm{F}$.

Figures 21 and 24 show the midplane (EL. 128") temperatures of the canister, liner and concrete during the intervals of July 24, 1979 to July 27, 1979 and 


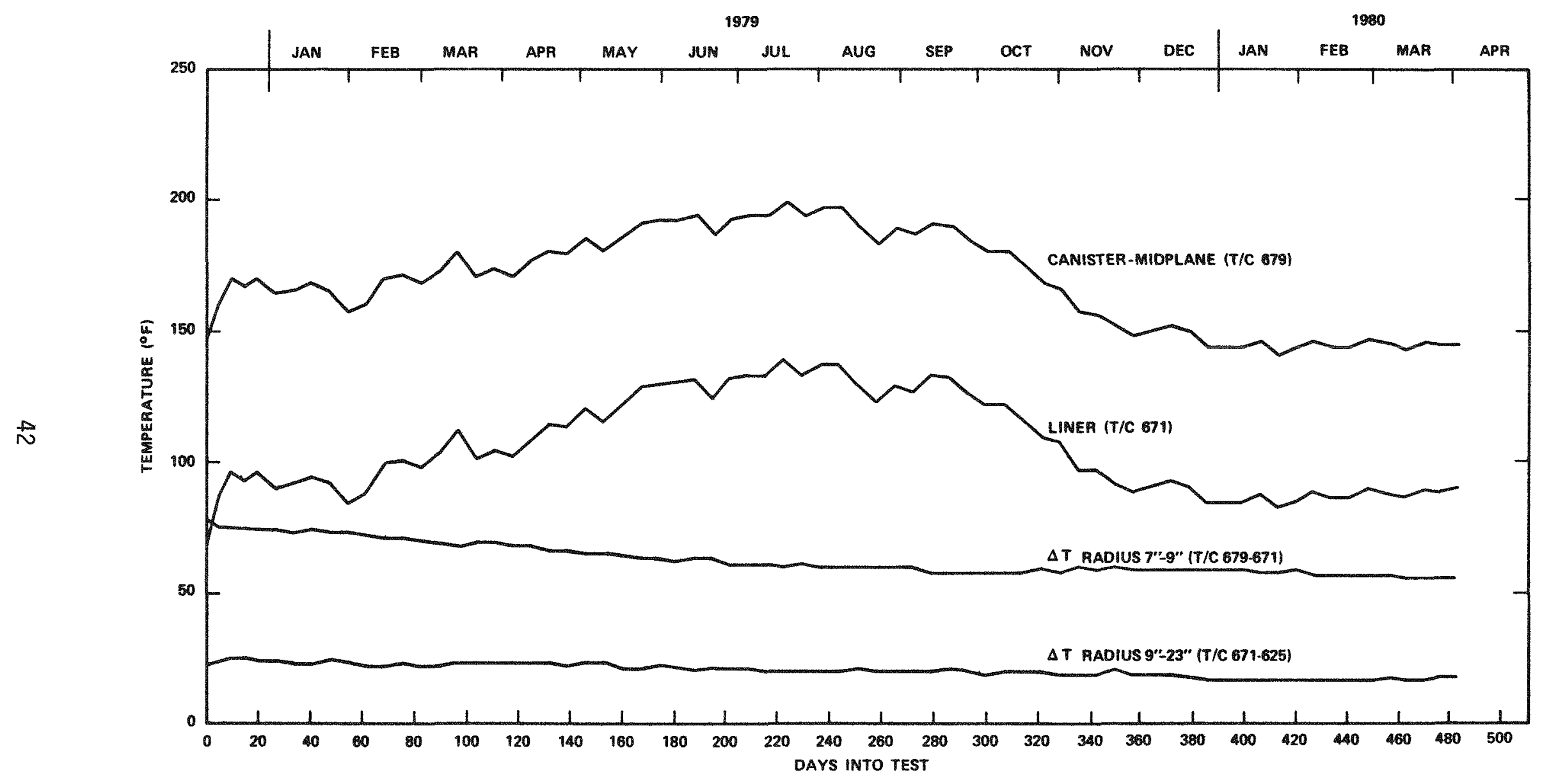

Figure 20. Maximum Temperature Distribution, Weekly Intervals, $45^{\circ}$ NE Quadrant, Elevation 128" 


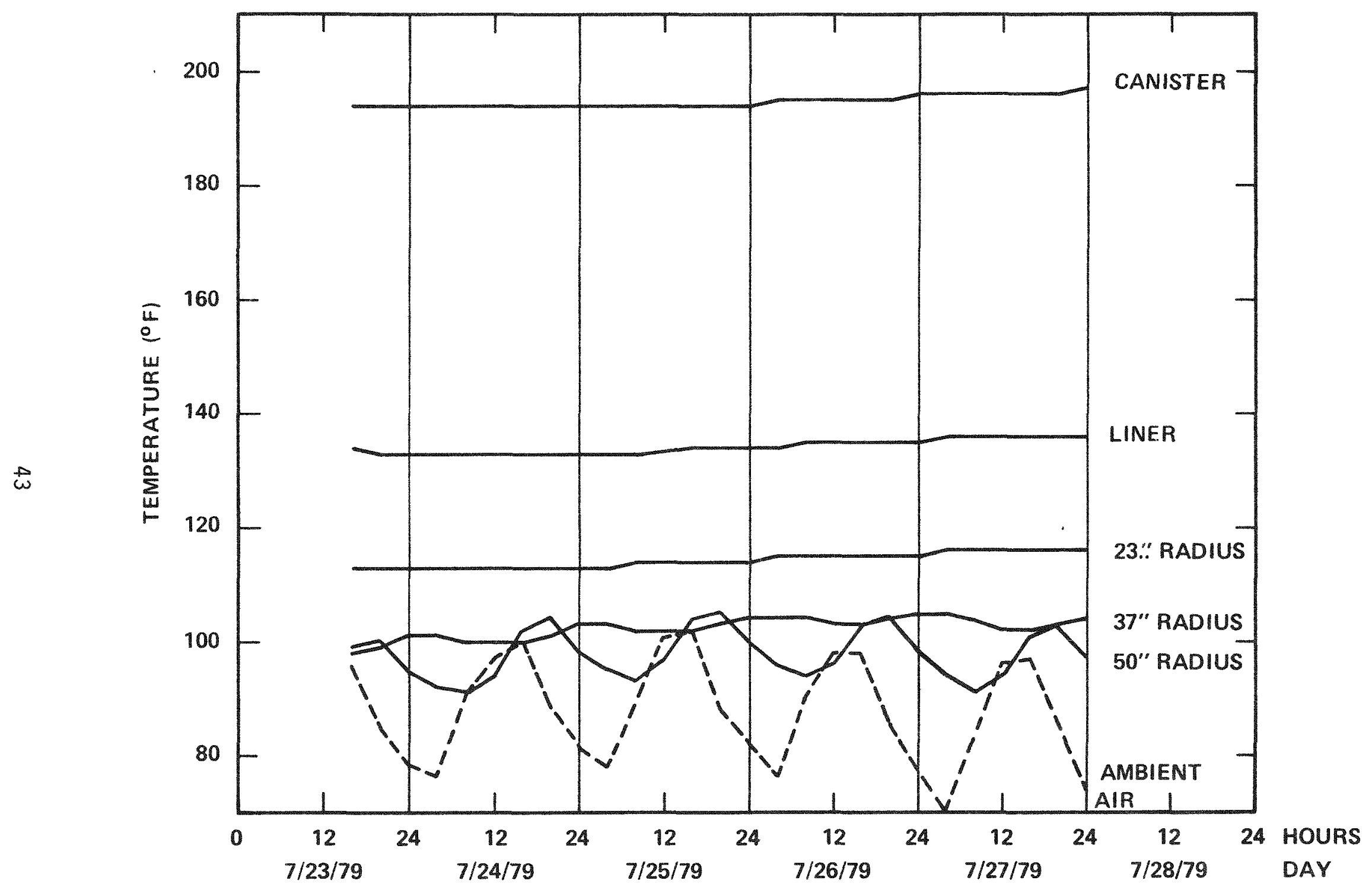

Figure 21. Temperature Distribution at 4 Hour Intervals, July 24, 1979 to JuTy 27, 1979, Elevation $128^{\prime \prime}, 45^{\circ}$ NE Quadrant 


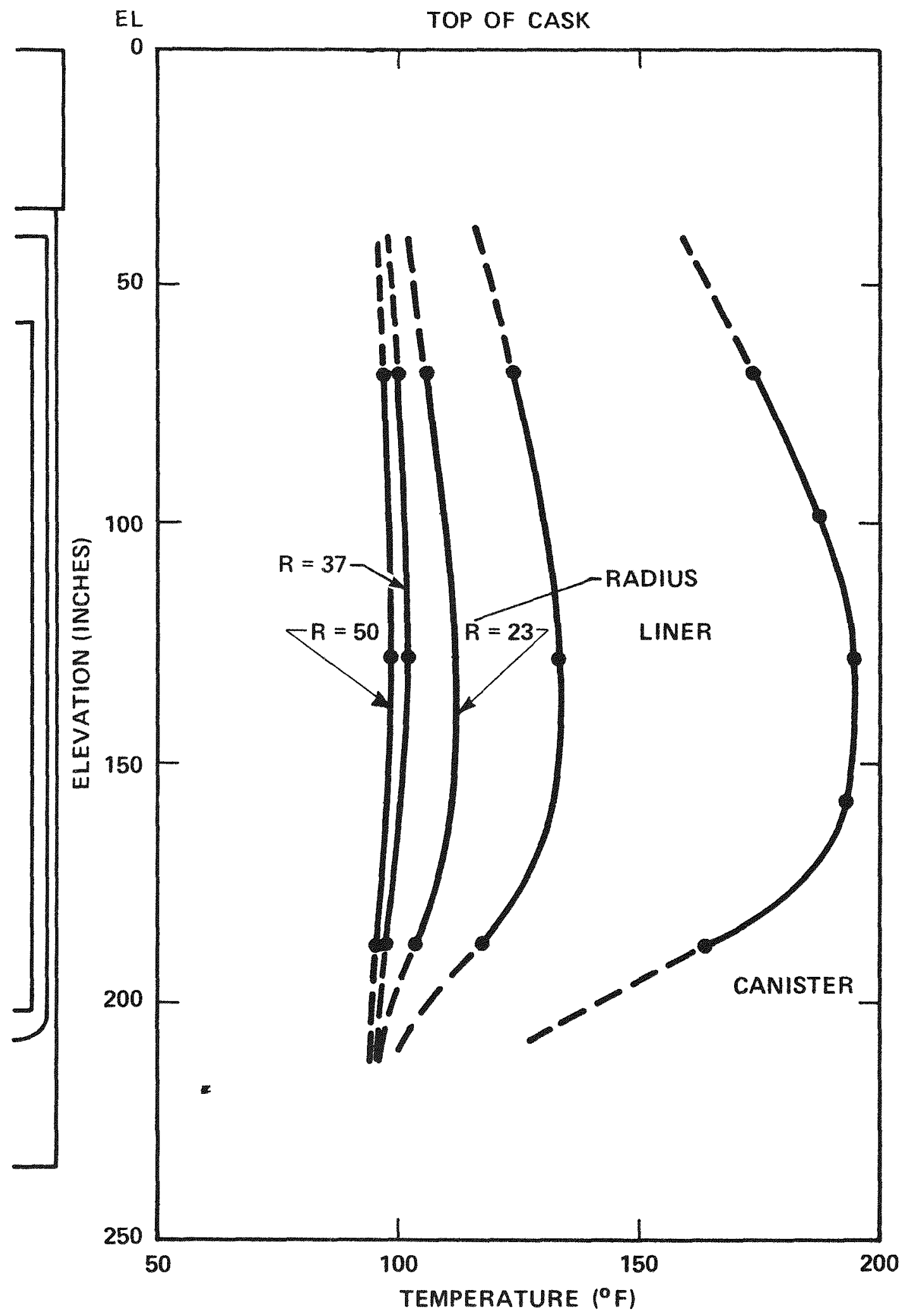

Figure 22. Axial Temperature Distribution, on July 24, 1979

(5427 Hours) Temperatures Averaged for 24 Hours 


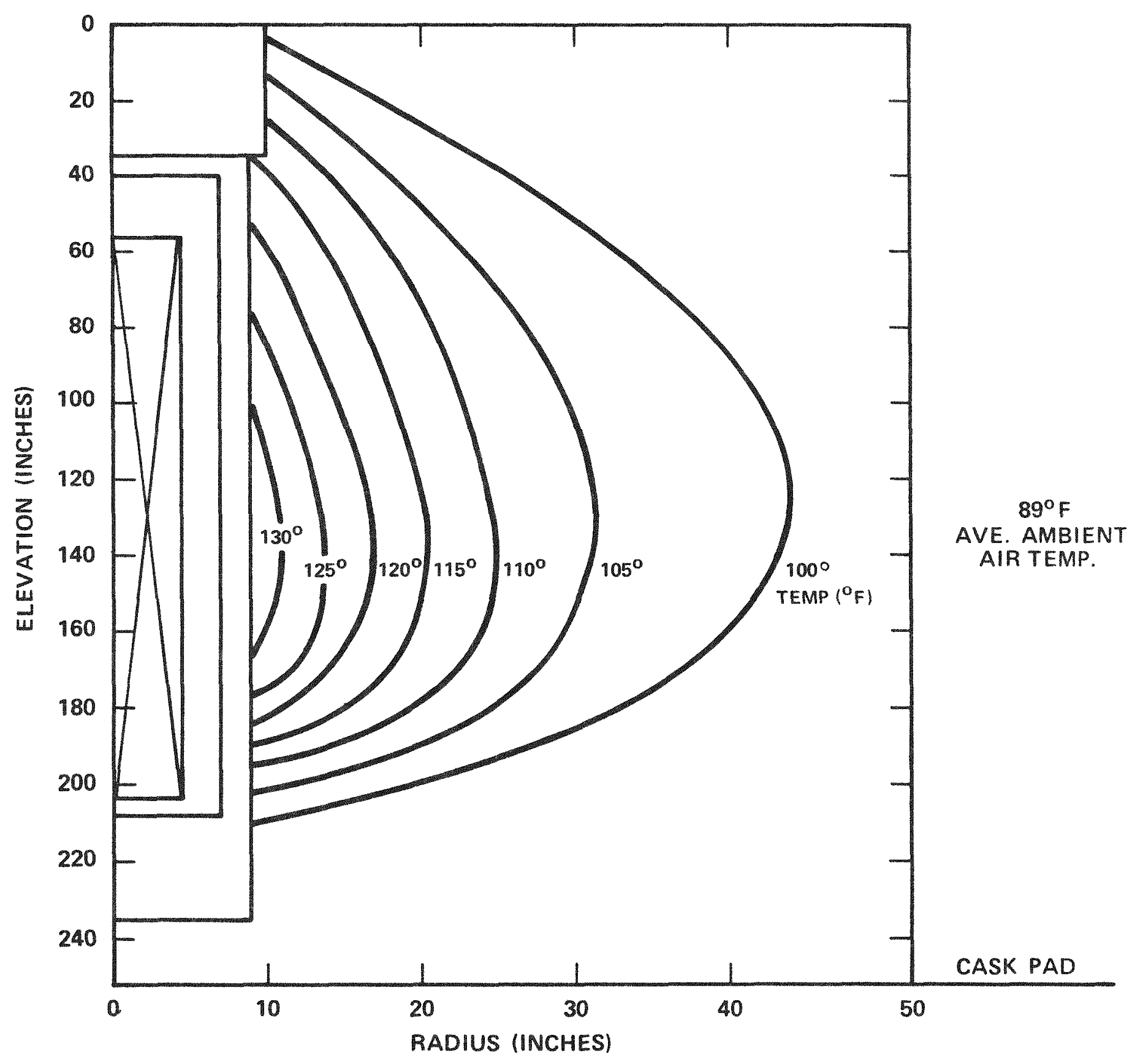

Figure 23. Isotherms on July 24, 1979 (5527 Hours) 


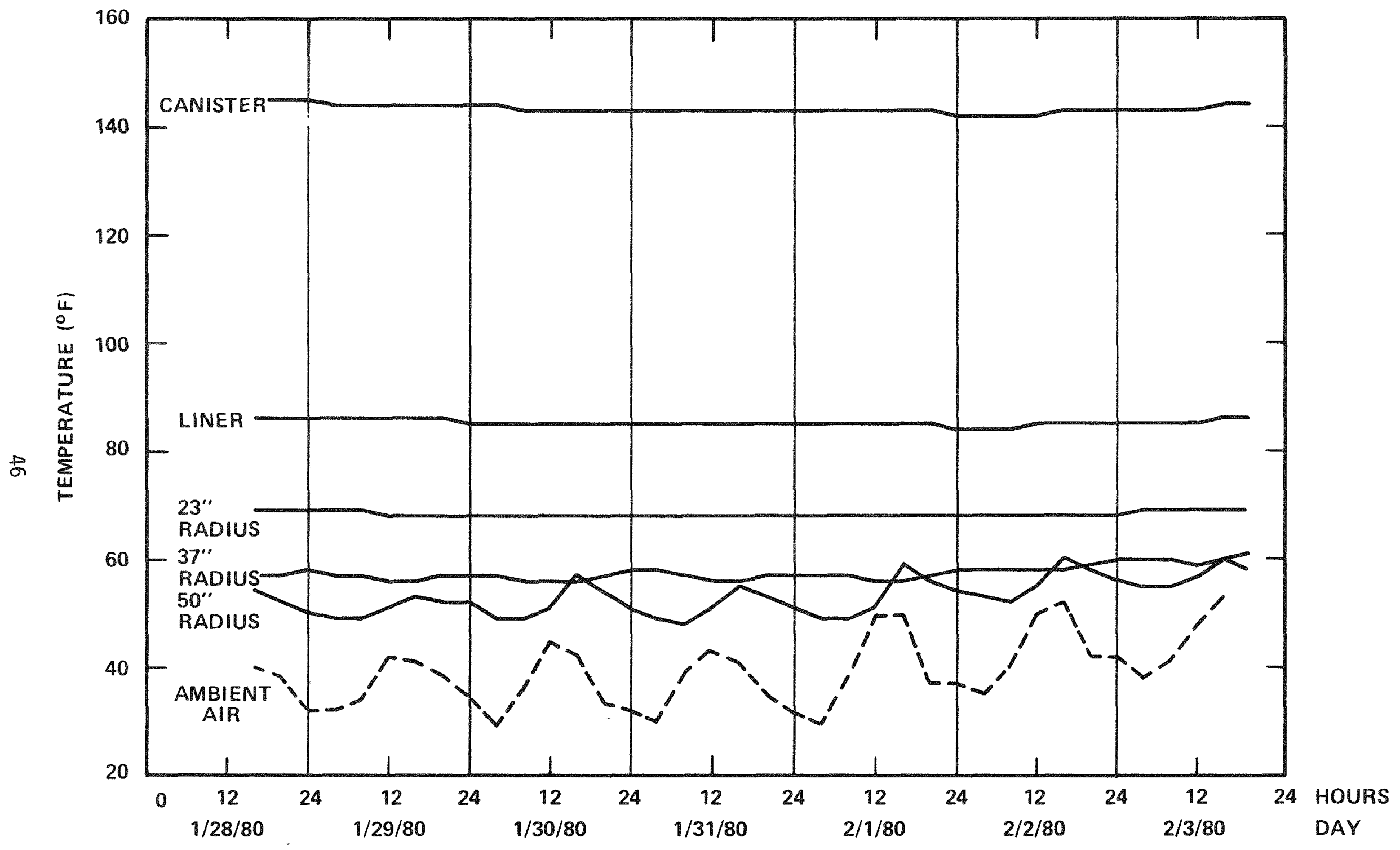

Figure 24. Temperature Distribution, 4 Hour Intervals, January 29, 1980 to February 3, 1980, Elevation 128", 45 NE Quadrant 

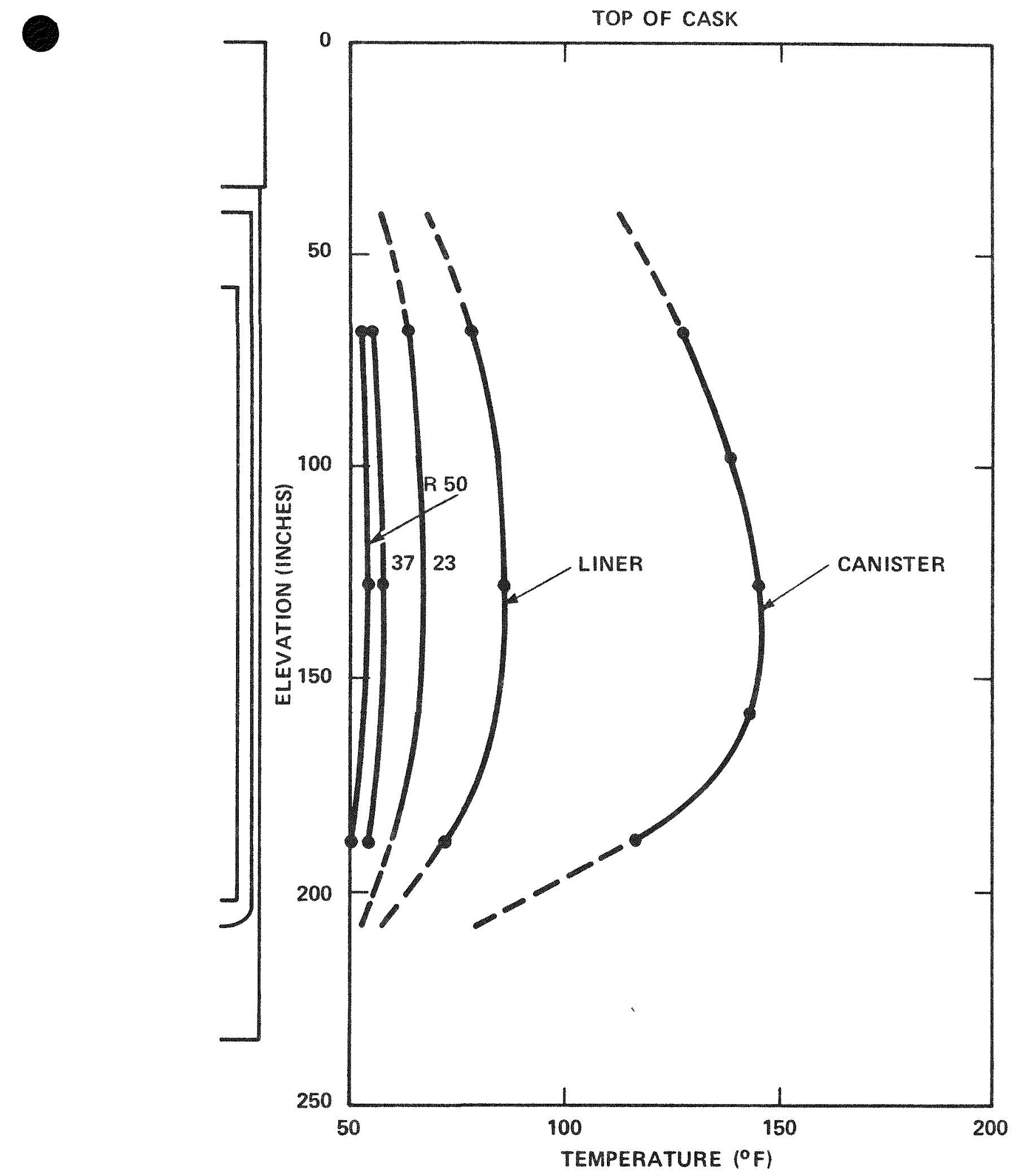

Figure 25. Axial Temperature Distribution on January 30, 1980, (9979 Hours), Temperatures Averaged for 24 Hours 


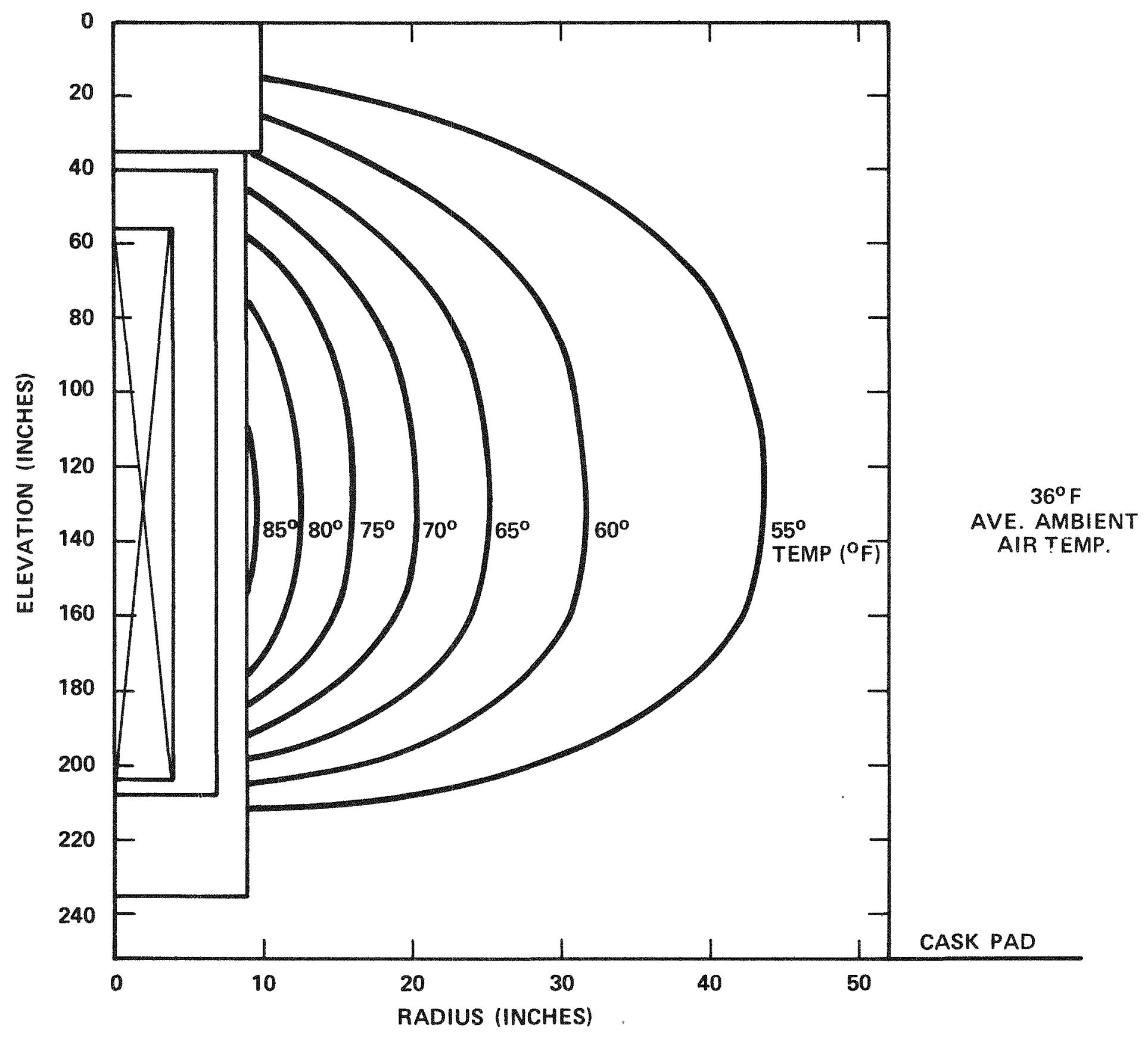

Figure 26. Isotherms on January 30, 1980 (9979 Hours) 
January 28, 1980 to February 2, 1980 and illustrate the effects of summer and winter operations and the effects of day-night variations. The day-night ambient variations are closely followed near the surface of the cask (50 inch radius); are nearly damped out at the 37 inch radius; and are not detectable at the

23 inch radius. Figures 22 and 25 show the canister, liner and concrete axial profiles on July 24, 1979 and on January 30, 1980. The temperature data was averaged over a 24 hour period to eliminate the effects of day-night variations in the concrete. Figures 23 and 26 present the temperature distribution on the same dates using isotherms interpolated from the thermocouple data.

\subsection{AMBIENT TEMPERATURE MEASUREMENTS}

A continuous record of atmospheric conditions at E-MAD has been kept during the SSC test. The average monthly air temperature at E-MAD from January, 1979 to February, 1980 is listed in Table 2. 
TABLE 2

MONTHLY AVERAGE AIR TEMPERATURE

AT E-MAD DURING TEST PERIOD

Month

\begin{tabular}{c} 
Average \\
Temperature $\left({ }^{\circ} \mathrm{F}\right)$ \\
\hline
\end{tabular}

January - 1979

37

February

47

March

53

Apri1

62

May

74

June

83

July

81

August

78

September

78

October

62

November

46

December

42

January - 1980

39

February

48

March

53 


\subsection{THERMAL ANALYSIS METHODS}

\subsection{ANALYSIS PURPOSE AND METHOD}

The purpose of the Sealed Storage Cask (SSC) Test thermal analys is is to establish a reference thermal model for the SSC configuration and to demonstrate that the model can produce satisfactory predictions of cask and canister temperatures. Once that goal is achieved, the model could be used with increased confidence in SSC analyses involving higher decay heat levels and cask design alterations.

Sealed Storage Cask Test predictions and data analyses have been performed using the TAP-A digital computer program, Reference 4. TAP-A was developed at AESD and has been used extensively during the past ten years at that division and at the Westinghouse Advanced Reactors Division. TAP-A is a finite difference program which calculates steady-state and transient temperature distributions in a configuration of solid materials utilizing the radiation, convection and conduction modes of heat transfer. To apply the program, a two-or three-dimensional configuration is divided into elements called nodes. The nodes, which are connected to each other by heat transfer links having lengths and cross-sectional areas, can have time and temperature dependent thermal properties (density, heat capacity and conductivity) as well as time dependent heat generation rates. Outer surfaces are assigned time dependent temperatures or convective heat transfer coefficients that may also vary with time or with a surface-to-ambient temperature differential.

In the analysis reported herein, temperature data from the SSC Test have been compared with TAP-A temperature predictions and reasonable model refinements have been made to improve the agreement. The rationale supporting those refinements and the sensitivity of temperature to variations in certain parameters are discussed in the following sections. 


\subsection{MODEL DESCRIPTION}

\subsubsection{MODEL SIZE AND BOUNDARY CONDITIONS}

The TAP-A nodal model of the SSC Test is depicted in Figure 27 and the 204 nodes representing each component are identified in Table 3 . The model is two dimensional in the $r$ and $z$ directions (radius and depth respectively) with no variations circumferentially.

\subsubsection{HEAT TRANSFER MECHANISMS}

Heat transfer between the fuel assembly (nodes 1 to 30) and the canister is modeled by conduction. Heat transfer from the fuel to canister actually occurs by convection and radiation (primarily by radiation at high temperatures). Since TAP-A has no mass flow capability and therefore cannot model convection effects, a simplifying assumption was made in the model to calculate canister temperatures utilizing an arbitrarily chosen conductivity value to represent the combination of radiation, convection, and conduction heat transfer. $A$ temperature dependent conductivity (Figure 28), calculated over the anticipated range of canister temperatures is used in the model. The fuel assembly heat capacity is modeled accurately to produce fairly accurate transient predictions for the entire SSC system.

Heat transfer from the canister to the liner and shield plug occurs by radiation, conduction and free convection and the thermal model considers all three modes. Convection and conduction are treated using the "effective thermal conductivity" approach while the radiation calculation for canister to liner heat transfer uses the following shape factor expression for concentric cylinders:

where

$$
F_{12}=\frac{1}{\frac{1}{\epsilon_{1}}+\frac{A_{1}}{A_{2}}\left(\frac{1}{\epsilon_{2}}-1\right)}
$$

$$
\begin{aligned}
& \epsilon=\text { emmisivity } \\
& A=\text { surface area } \\
& 1=\text { canister outer surface } \\
& 2=\text { Iiner inner surface }
\end{aligned}
$$




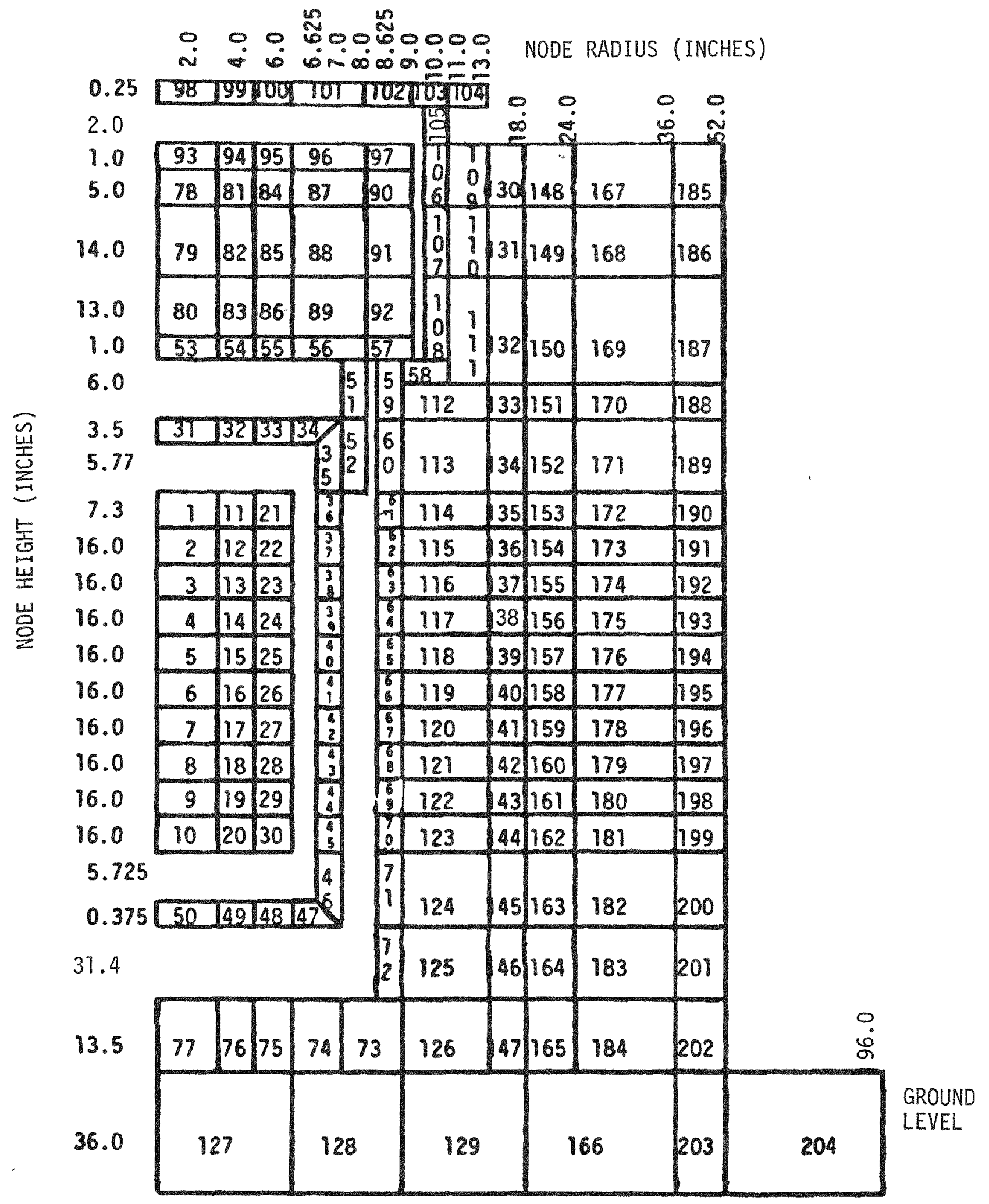

Figure 27. Sealed Storage Cask Thermal Model 
TABLE 3

SSC TAP-A MODEL NODE DESCRIPTION

\begin{tabular}{ll}
$\frac{\text { Nodes }}{1-30}$ & \multicolumn{1}{c}{ Description } \\
31-50 & Fuel Assembly \\
$51-52$ & Canister \\
$53-57$ & Shield Plug Extension \\
58 & Shield Plug Bottom Plate \\
$59-72$ & Liner Transition Ring \\
$73-77$ & Liner Center Section \\
$78-92$ & Liner Lower Section \\
$93-97$ & Shield Plug Concrete \\
$98-104$ & Shield Plug Top Plate \\
$105-108$ & SSC Cover \\
$109-126$ & Liner Upper Section \\
$127-129$ & SSC Concrete \\
$130-165$ & Concrete Pad \\
166 & SSC Concrete \\
$167-202$ & Concrete Pad \\
$203-204$ & SSC Concrete \\
& Concrete Pad
\end{tabular}




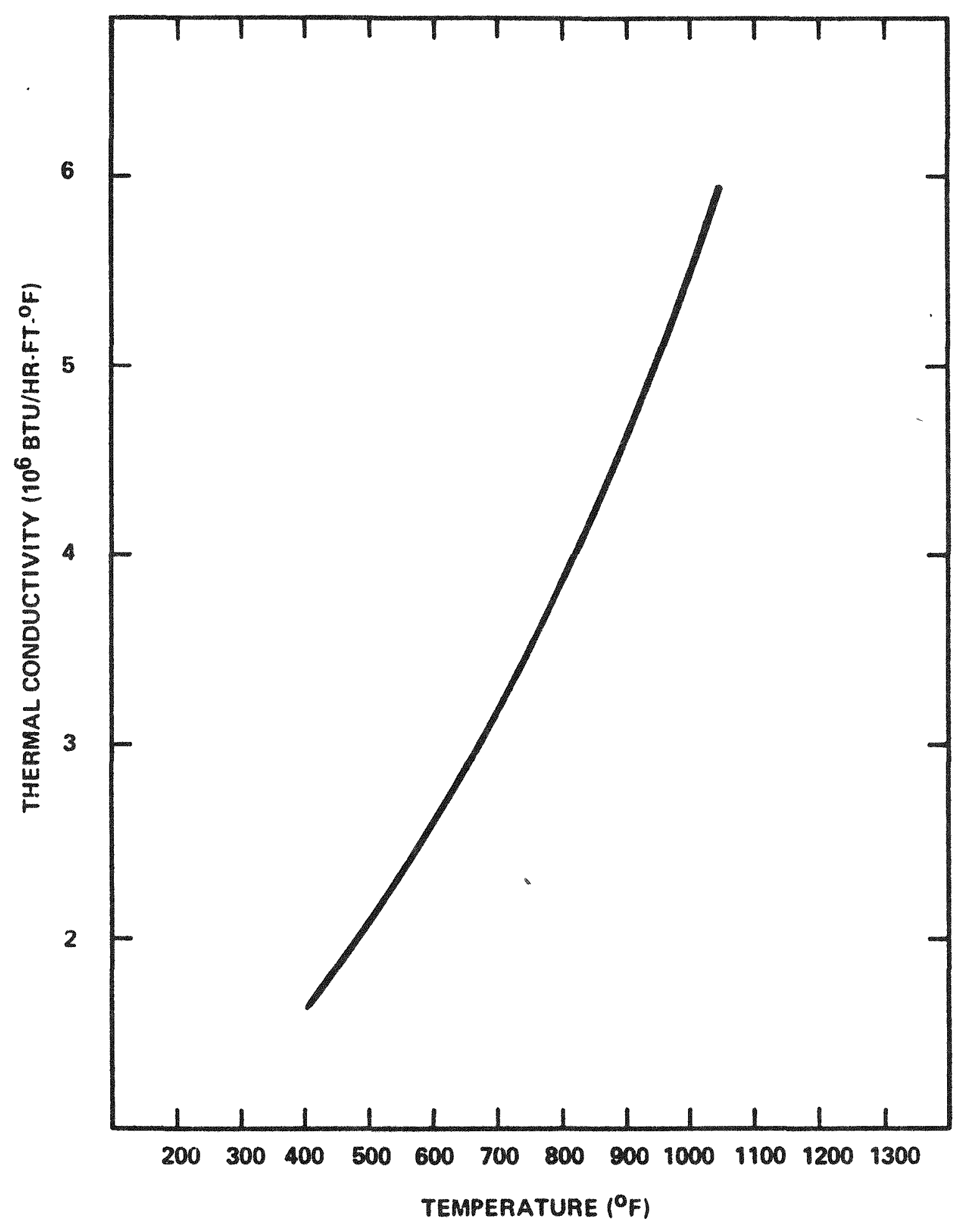

$615440.9 A$

Figure 28. Thermal Conductivity Within Modeled Fuel Assembly 
Emissivity values for the canister $(0.45)$ and liner $(0.60)$ were obtained from References $5(p .475)$ and $6(p .15-21)$, respectively, and they apply to Type 304 stainless steel for the canister and to hot rolled steel for the liner. The resulting shape factor value $(0.36)$ is also applied to calculations between the canister and shield plug and between the canister and the liner section at the bottom of the SSC. The axial radiation heat transfer model is judged to be acceptable since data show heat transfer rates vertically through the shield plug and from the canister's lower end to be typically less than 2 percent of the total heat generation rate in the fuel assembly.

The free convection heat transfer between the canister and liner is modeled per Reference 7 by heat transfer in enclosed spaces. The function

$$
N_{u}=\frac{\overline{h b}}{k}=0.065 \mathrm{Gr}^{1 / 3}\left(\frac{L}{b}\right)^{-1 / 9}
$$

where:

$$
\begin{aligned}
& N u=\text { Average Nusselt number } \\
& \bar{h}=\text { Average heat transfer coefficient } \\
& k=\text { Thermal conductivity } \\
& b=\text { Width of enclosed space } \\
& G r=\text { Grashof number } \\
& L=\text { Heated length }
\end{aligned}
$$

is used to determine the heat transfer coefficient due to natural convection between the canister and liner. For the parameters of the SSC, the heat transfer coefficient of $0.35 \mathrm{Btu} / \mathrm{hr}-\mathrm{ft} \mathrm{t}^{2}{ }^{\circ} \mathrm{F}$ is used.

Heat transfer from the shield plug sides to the upper liner occurs primarily by radiation and free convection and by convection from the upper surface of the shield plug to the SSC cover plate. For modeling purposes, conduction through an air-filled space is assumed in each direction. This approach is used since 
TAP-A has no mass flow capabilities. This simplifying assumption is judged to be acceptable since, due to the relatively small shield plug heat transfer rates, even large modeling inaccuracies in these regions would have little effect on canister temperature predictions. The values used for these heat transfer areas are shown in Table 4.

The interface between two solid materials in contact will produce a certain resistance to the flow of heat across the boundary. In this analysis, however, intimate contact is assumed between the liner and concrete and the contact resistance was assigned zero value.

\subsubsection{FUEL ASSEMBLY}

The fuel assembly is modeled as a uniform axial and radial heat generating medium with a power decay described in Figure 12 for this type of PWR fue 1. The heat source is modeled as a right circular cylinder 144 inch long and 12 inch diameter with a thermal conductivity as shown in Figure 28. No attempt was made to model the individual fuel pins. An attempt was made to maintain the approximate heat capacity of the fuel region to more closely predict the canister and fuel temperature during transient heatup and ambient temperature changes. The fuel assembly was placed in the SSC in December, 1978 when the power level of the fuel assembly was approximately $1.1 \mathrm{~kW}$ (see Figure 12). The fuel power level then decays gradually to $0.7 \mathrm{~kW}$ at the end of March, 1980.

\subsubsection{OUTSIDE SURFACE OF SSC}

On the outside surface of the SSC several heat transfer processes occur: solar insolation, solar reflection, radiation back to sky and convection to and from the ambient air. Of these processes, solar effects are not considered. Test data has shown that the day-night solar effects are (on the south side of the SSC) damped out in the first 15 inches of concrete. Heat transfer by convection at the concrete/air interface is modeled by supplying a convective heat transfer coefficient at the interface and monthly air temperature averages calculated from E-MAD site weather data (see Table 2). The heat transfer coefficient is assigned a constant value of $2.0 \mathrm{Btu} / \mathrm{hr}-\mathrm{Ft} \mathrm{t}^{2}-\mathrm{F}$ (obtained from 
TABLE 4

THERMAL CONDUCTIVITY COEFFICIENTS REPRESENTING CONVECTION AND CONDUCTION AT VARIOUS SSC INTERFACES

\begin{tabular}{|c|c|c|c|c|}
\hline $\begin{array}{l}\text { Temperature } \\
\left({ }^{\circ} \mathrm{F}\right)\end{array}$ & $\begin{array}{l}\text { Between Top of } \\
\text { Canister and } \\
\text { Bottom of Shield Plug } \\
\text { (Btu/hr-ft- }{ }^{\circ} \text { ) }\end{array}$ & $\begin{array}{l}\text { Between Shield } \\
\text { Plug and Liner } \\
(\text { Btu/hr-ft-o } F)\end{array}$ & $\begin{array}{c}\text { Between Canister } \\
\text { and Liner } \\
\left(\text { Btu/hr-Ft- }{ }^{\circ} \mathrm{F}\right) \\
\end{array}$ & $\begin{array}{c}\text { Between Canister } \\
\text { and Bottom of } \\
\text { Liner } \\
\left(\mathrm{Btu} / \mathrm{hr}-\mathrm{ft}-{ }^{\circ} \mathrm{F}\right) \\
\end{array}$ \\
\hline 100 & 0.00256 & 0.0212 & 0.058 & 0.00064 \\
\hline 300 & 0.00321 & 0.0266 & 0.058 & 0.00080 \\
\hline 500 & 0.00384 & 0.0318 & 0.058 & 0.00096 \\
\hline
\end{tabular}


Reference 7) and applies to a wind speed of 5 to 10 miles/hour for a direction perpendicular to the SSC surface.

Radiative heat transfer to the sky from the concrete cylinder and the SSC cover plate is calculated using the following emissivity values from Reference 8 , (p. 699):

$\begin{array}{lc}\text { Component } & \text { Emissivity } \\ \text { SSC cover plate-gray paint } & 0.95 \\ \text { Concrete } & 0.9\end{array}$

\section{2 .5 MATERIAL PROPERTIES}

The various materials used in the SSC test and thermal properties which were input to the thermal model are identified in Table 5. The physical and thermal properties of concrete were measured as a function of temperature in laboratory tests performed by Holmes and Narver, Inc. The results of that work are shown in Table 6. An effective thermal conductivity of the concrete must take into account the reinforcing bar used in the construction of the SSC. A thermal conductivity value of $1.7 \mathrm{Btu} / \mathrm{hr}-\mathrm{ft}-{ }^{\circ} \mathrm{F}$ is used in the thermal model which best describes the radial temperature profile through the concrete. Appendix $C$ provides several calculational methods which were used in determining the concrete thermal conductivity from the test data. 
TABLE 5

MATERIAL THERMAL PROPERTIES USED IN ANALYSIS

\begin{tabular}{|c|c|c|c|c|}
\hline Material & $\begin{array}{l}\text { Density } \\
\left(1 \mathrm{~b} / \mathrm{in}^{3}\right) \\
\end{array}$ & $\begin{array}{l}\text { Heat Capacity } \\
\left(\text { Btu/1b- }{ }^{\circ} \text { F) }\right.\end{array}$ & $\begin{array}{l}\text { Thermat Conductivity } \\
\left(\text { Btu/hr-ft- }{ }^{\circ} \mathrm{F}\right)\end{array}$ & Emissivity \\
\hline Fuel Assembly & 0.170 & 0.10 & See Figure 28 & - \\
\hline Stainless Steel & 0.289 & 0.12 & 9.9 & .45 \\
\hline Carbon Steel & 0.283 & 0.12 & 23.0 & .60 \\
\hline Concrete & 0.083 & 0.21 & 1.7 & .90 \\
\hline
\end{tabular}


TABLE 6

SSC \#2 CONCRETE PROPERTIES

TEMPERATURE

( $\left.{ }^{\circ} \mathrm{F}\right)$

Room

100

200

300

400

500

600

700

* No Data $\frac{\text { THERMAL CONDUCTIVITY }}{\text { Bottom }} \frac{\left.\text { Btu/hr-ft- }{ }^{\circ} \mathrm{F}\right)}{\text { Middle }}$

1.29

1.23

1.37

$-*$

0.95

1.02

1.04

0.90

0.92

0.97

0.80

0.90

0.91

0.78

0.80

0.70

0.74

0.72

0.65

0.66

0.69

0.54

0.51

0.62

TEMPERATURE

$\left({ }^{\circ} \mathrm{F}\right)$

100

Bottom

SP

0.222

0.232

0.241

0.251

700

400

500

SPECIFIC HEAT ( $\left.\mathrm{Btu} / 1 \mathrm{~b}-{ }^{\circ} \mathrm{F}\right)$

Middle Top

$0.215 \quad 0.213$

$0.224 \quad 0.222$

0.234

0.232

0.244

0.241

600

0.253

0.251

COEFFICIENT OF THERMAL EXPANSION AND DENSITY

Test

Density $\left(1 \mathrm{~b} / \mathrm{ft}^{3}\right)$

Coefficient of

Thermal Expansion $\left(10^{-6} /{ }^{\circ} \mathrm{F}\right)$
0.260

0.270

Bottom

142

6.0

0.263

0.260

0.272

0.270
Middle Top

145

144

6.0

6.2 


\subsection{THERMAL ANALYSIS RESULTS}

\subsection{MODEL EVALUATION CRITERIA}

With proper input, a SSC thermal analysis model should produce accurate temperature predictions for the canister, liner, and concrete. Accurate canister temperatures are important as input to independent fuel assembly studies while accurate concrete temperatures are important to SSC stress analyses. Of greater importance is the need to correctly predict temperature trends and relationships for a range of power levels with seasonal temperature variations. Satisfying this objective will demonstrate that the analysis can correctly model the appropriate heat transfer mechanisms and maintain the proper relationships between them as system forcing functions and boundary conditions change. As long as the model satisfies this requirement, small systematic differences between predicted and measured temperatures should not be of concern. In most cases, their existence will be recognized and explained based upon model input uncertainty.

With these criteria in mind, the sections to follow will present a comparison of TAP-A temperature predictions with data from the SSC Test.

\subsection{MODEL/DATA COMPARISON}

The SSC was thermally analyzed over a 1.5 year time period from installation of the fuel canister in December, 1978 to July, 1980. A computer printout of the temperatures in the SSC at monthly intervals (the printouts are shown in Appendix B) were then compared to the actual temperature data. Figure 29 shows the monthly canister and liner maximum temperature comparisons at the 128 inch elevation position for the thermal model and actual data. From Figure 29 it can be seen that good agreement with the liner temperatures are obtained over the complete life of the test. This shows that using the monthly averaged air temperature approach for boundary condition is a reasonably good way to analyze the SSC. The data shows that the solar heating effect on the south side of the 


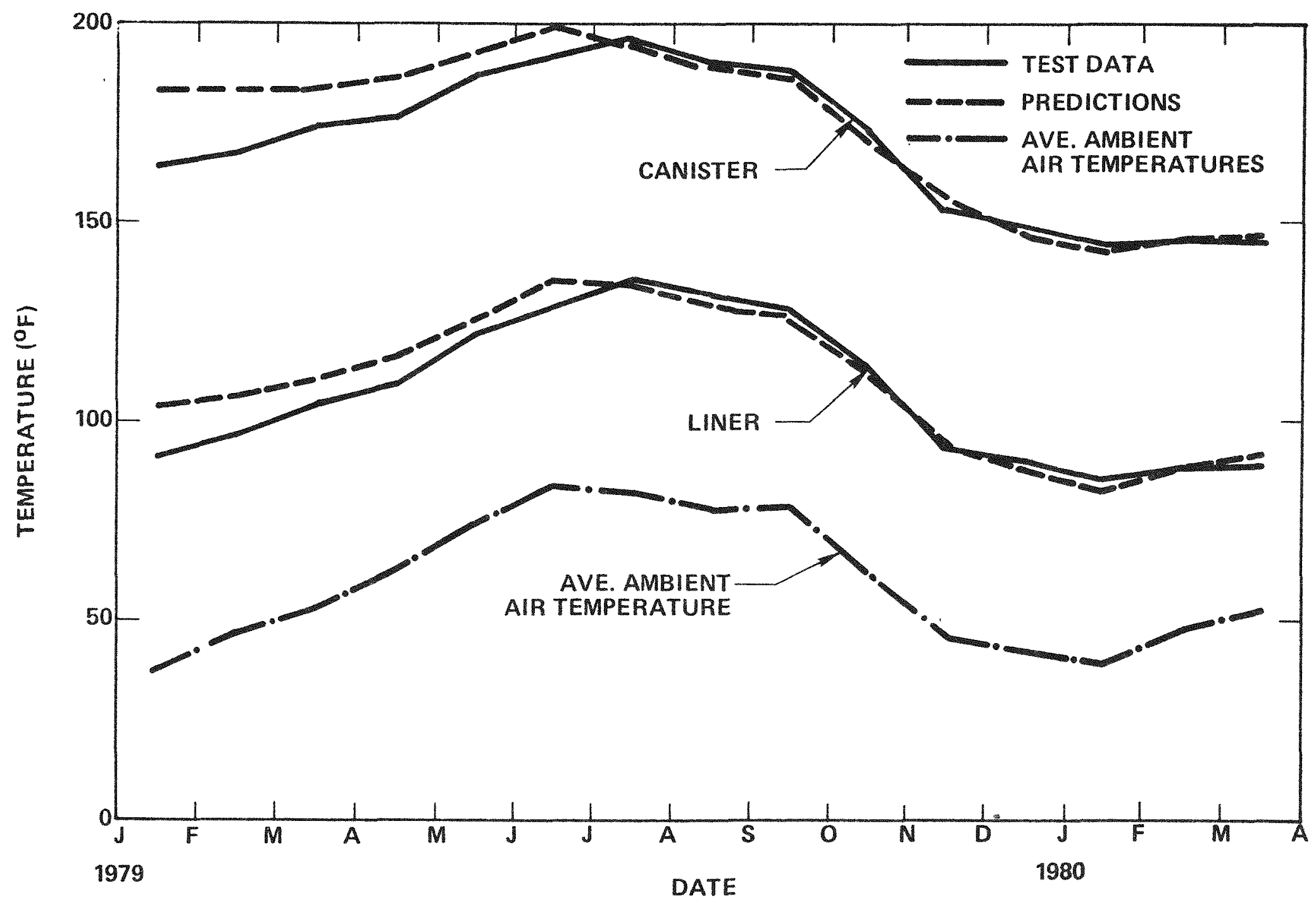

705397-1A

Figure 29. Test Data and Predictions Comparison of Monthly Average Midplane (Elevation 128") Temperatures 


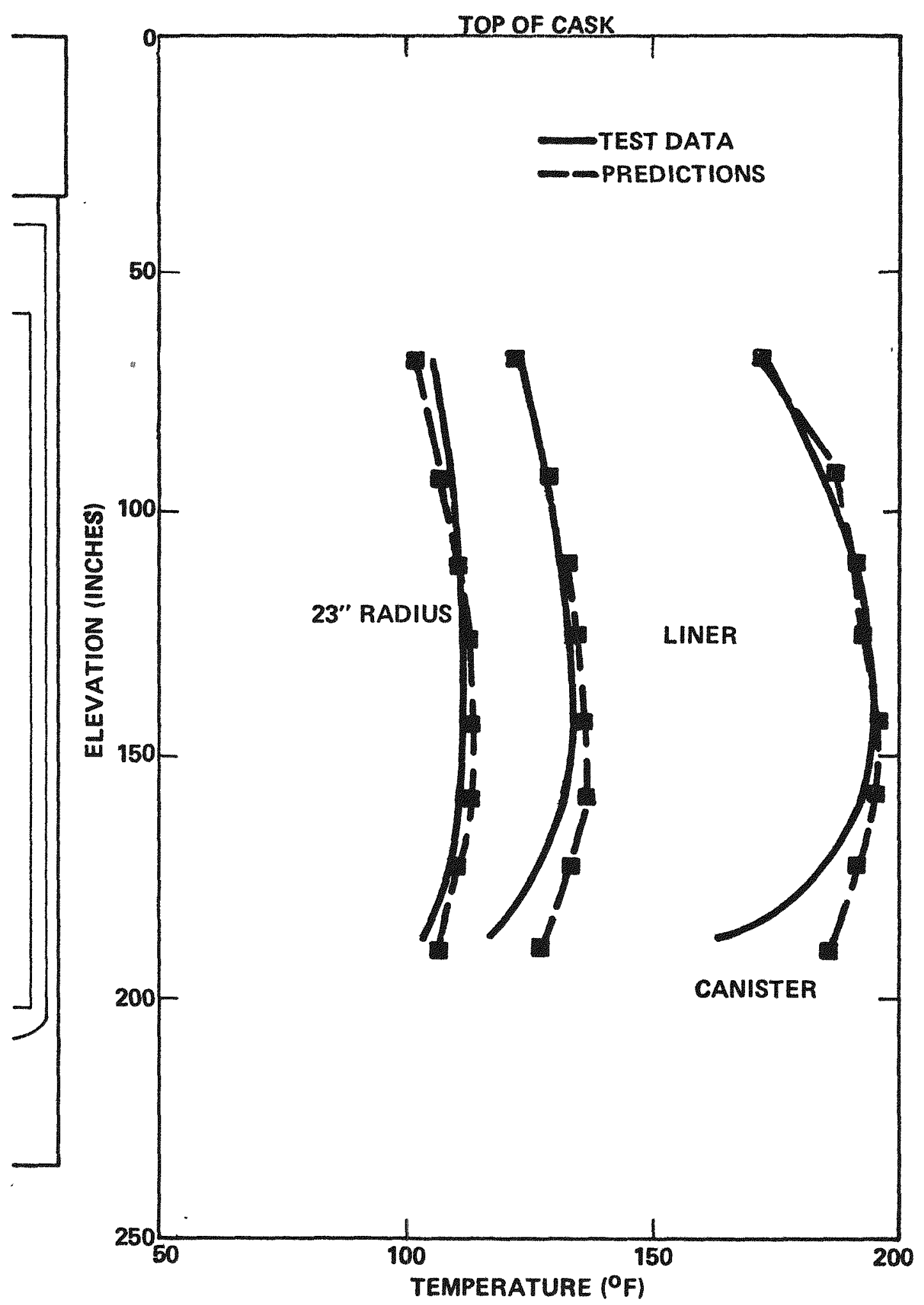

$705368.2 A$

Figure 30. Test Data and Prediction Comparison of Axial Temperature Distribution on July 24, 1979 (5427 Hours) 
SSC doesn't influence the liner temperature to any large degree. Hence, solar effects can be ignored when determining liner and canister temperatures.

The maximum canister temperature predictions are reasonably good when compared with the data. The thermal model tends to overpredict the canister temperature early in the test (January through July, 1979) by about 10 to $20^{\circ} \mathrm{F}$. Later on, the results show excellent agreement between the canister temperature predictions and data.

Figure 30 shows a comparison of the axial temperature profiles for the canister, liner and one radial position in the concrete on July 24, 1979. The predictions are higher than the data in the lower section of the SSC near the canister bottom, but show excellent agreement elsewhere. The maximum values are in good agreement everywhere. The lower section between the canister and the liner bottom was conservatively modeled by conduction and radiation only. A better method would be to account for natural convection also, which would then have lowered the the temperature of the canister in this region. Likewise, for conservatism, radiation heat transfer was not used in the internals of the canister from the fuel to the canister, hence less heat was allowed to go axially downward to the bottom of the canister, which would have reduced the temperatures along the side of the canister in this lower region.

A comparison of the radial temperature profile in July, 1979 is shown in Figure 31. This figure shows the temperature comparison at the maximum temperature axial position. Good agreement between the thermal model and data is shown by this comparison. This shows that the effective thermal conductivity of SSC concrete of 1.7 which includes the reinforcing bar and the decay heat power used in the thermal analysis were reasonable values in predicting the actual radial temperature profiles. 


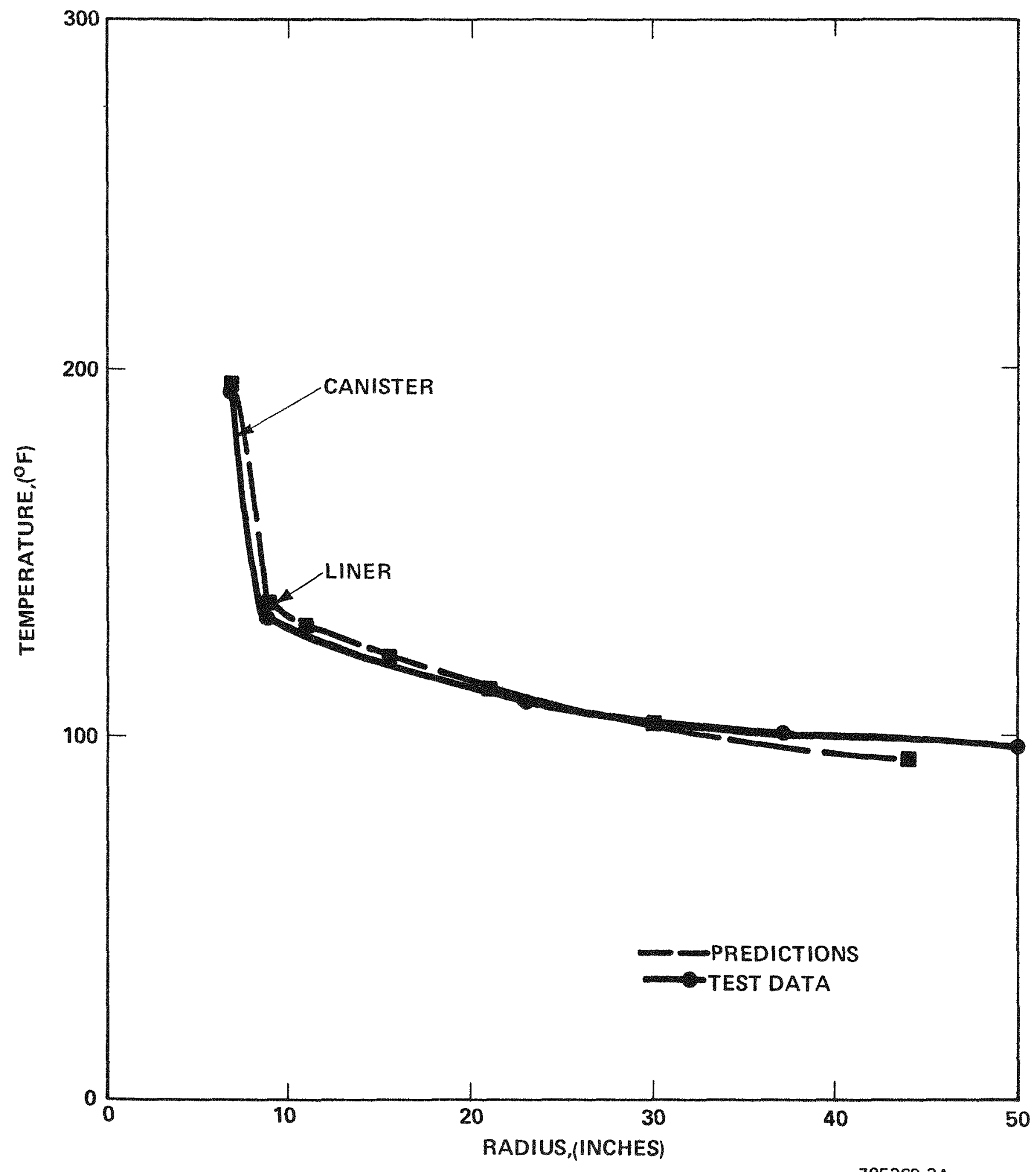

$705368-3 \mathrm{~A}$

Figure 31. Test Data and Predictions Comparison of Radial Temperature Distribution at Elevation 128" on July 24, 1979 (5427 Hours) 


\subsection{REFERENCES}

1. NV0-198, Safety Assessment Document for the Spent Fuel Handling and Packaging Program Demonstration at the Nevada Test Site, U. S. Department of Energy, December, 1978.

2. DOE/NV/00597-5, "Spent Fuel Dry Storage Technology Development: Themal Evaluation of Isolated Drywells Containing Spent Fuel $11 \mathrm{~kW}$ PUR Spent Fuel Assemhly)," Westinghouse Advanced Energy Systems Division, September 1980.

3. HEDL-TME-79-68, Data Report for the Nondesctuctive Examination of Turkey Point Spent Fuel Assemblies B02, B03, B17, B41 and B43, Hanford Engineering Development Laboratory, Apri 1, 1980.

4. WANL-TME-1872, Pierce, B. L., and Stumpf, H. J., "TAP-A Program for Computing Transient or Steany-State Temperature Distributions, "Westinghouse Astronuclear Laborabory (now Advanced Energy Systens Division), December, 1969.

5. McAdams, H. H., "Heat Transmission," McGral-Hill Book Co., Third Edition, 1954.

6. Rohsenow, W. M. , and Hartnett, J. P., "Handbook of Heat Transfer," McGrawHill Book Co., 1973.

7. Jakoh, M. "Heat Transfer," Volume 1, John Wiley \& Sons, Sixth Printing, March, 1958.

8. Kreith, F., and Kreider, J.F., "Principles of Solar Engineering," Hemisphere Pubiishing Co., 1978. 


\section{APPENDIX A \\ SEALED STORAGE CASK TEST DATA}

Test data are provided in this Appendix for the SSC thermocouples. Table 1 of the text provides the detail information on the location of the SSC \#2 thermocouples. Table A-1 through A-16 provides data logger printouts of the thermocouple readings.

\begin{tabular}{llc} 
Table & $\frac{\text { Date }}{1 / 15 / 79}$ & Operating Hours \\
\hline $\mathrm{A}-1$ & $2 / 15 / 79$ & 937 \\
$\mathrm{~A}-2$ & $3 / 15 / 79$ & 1681 \\
$\mathrm{~A}-3$ & $4 / 15 / 79$ & 2353 \\
$\mathrm{~A}-4$ & $5 / 14 / 79$ & 3097 \\
$\mathrm{~A}-5$ & $6 / 18 / 79$ & 3793 \\
$\mathrm{~A}-6$ & $7 / 15 / 79$ & 4633 \\
$\mathrm{~A}-7$ & $8 / 15 / 79$ & 5281 \\
$\mathrm{~A}-8$ & $9 / 15 / 79$ & 6025 \\
$\mathrm{~A}-9$ & $10 / 14 / 79$ & 6769 \\
$\mathrm{~A}-10$ & $11 / 16 / 79$ & 7465 \\
$\mathrm{~A}-11$ & $12 / 15 / 79$ & 8287 \\
$\mathrm{~A}-12$ & $1 / 15 / 80$ & 8953 \\
A-13 & $2 / 16 / 80$ & 9713 \\
A-14 & $3 / 15 / 80$ & 10465 \\
A-15 & $4 / 15 / 80$ & 11137 \\
A-16 & & 11881
\end{tabular}


TABLE A-1

SSC \#2"TEST - TEMPERATURE DISTRIBUTION

DATE: $\quad 1 / 15 / 79$

TIME: $\quad 16: 00$

OPERATING HOURS: 937

THERMOCOUPLE READINGS

\begin{tabular}{cccc} 
T/C No. & Temp $\left({ }^{\circ} \mathrm{F}\right)$ & T/C No. & Temp $\left({ }^{\circ} \mathrm{F}\right)$ \\
\cline { 2 - 4 } 654 & 52.9 & 683 & 130.9 \\
653 & 61.1 & 682 & 136.6 \\
652 & 77.6 & 681 & 17.4 \\
651 & 47.7 & 680 & 166.1 \\
650 & 57.5 & 679 & 169.0 \\
649 & 69.2 & 678 & 170.0 \\
648 & 96.1 & 677 & 163.8 \\
647 & 46.4 & 676 & 162.5 \\
646 & 54.6 & 675 & 151.3 \\
645 & 65.1 & 674 & 148.2 \\
644 & 86.6 & 673 & 78.9 \\
643 & 54.2 & 672 & 78.8 \\
642 & 45.7 & 671 & 96.0 \\
641 & 63.3 & 670 & 87.3 \\
640 & 77.7 & 669 & 82.3 \\
639 & 47.4 & 668 & 45.7 \\
638 & 58.4 & 667 & 50.3 \\
637 & 72.7 & 666 & 77.5 \\
636 & 96.5 & 665 & 47.0 \\
635 & 46.2 & 664 & 55.3 \\
634 & 54.8 & 663 & 67.2 \\
663 & 67.1 & 662 & 45.2 \\
632 & 88.9 & 661 & 53.1 \\
631 & 46.2 & 660 & 63.3 \\
630 & 51.8 & 659 & 83.3 \\
629 & 61.4 & 658 & \\
628 & 77.4 & 657 & \\
627 & 47.7 & 656 & \\
626 & 56.1 & 655 & \\
625 & 72.1 & & \\
624 & 95.2 & & \\
623 & 46.5 & & \\
622 & 54.4 & & \\
621 & 65.1 & & \\
620 & 86.0 & &
\end{tabular}


TABLE A-2

SSC \#2 TEST - TEMPERATURE DISTRIBUTION

DATE: $2 / 15 / 79$

TIME: $\quad 16: 00$

OPERATING HOURS: 1681

THERMOCOUPLE READINGS

\begin{tabular}{cccc} 
T/C No. & Temp $\left({ }^{\circ} \mathrm{F}\right)$ & T/C No. & Temp $\left({ }^{\circ} \mathrm{F}\right)$ \\
\cline { 2 - 3 } 654 & 59.9 & 683 & 132.8 \\
653 & 66.8 & 682 & 138.5 \\
652 & 82.0 & 681 & 172.6 \\
651 & 83.8 & 680 & 167.2 \\
650 & 65.5 & 679 & 170.9 \\
649 & 75.1 & 678 & 172.2 \\
648 & 100.6 & 677 & 165.8 \\
647 & 84.7 & 676 & 164.8 \\
646 & 63.0 & 675 & 153.6 \\
645 & 71.7 & 674 & 150.4 \\
644 & 91.7 & 673 & 83.0 \\
643 & 60.2 & 672 & 82.8 \\
642 & 60.1 & 671 & 100.3 \\
641 & 68.3 & 670 & 100.5 \\
640 & 81.9 & 669 & 92.3 \\
639 & 66.0 & 668 & 87.6 \\
638 & 65.4 & 667 & 55.1 \\
637 & 78.2 & 666 & 55.5 \\
636 & 100.8 & 665 & 64.2 \\
635 & 65.8 & 664 & 81.6 \\
634 & 62.6 & 663 & 57.6 \\
633 & 73.3 & 662 & 60.7 \\
632 & 93.8 & 661 & 72.7 \\
631 & 54.8 & 660 & 99.7 \\
630 & 57.2 & 659 & 57.7 \\
629 & 66.5 & 658 & 59.0 \\
628 & 81.7 & 657 & 69.2 \\
627 & 58.4 & 656 & \\
626 & 61.7 & 655 & \\
625 & 77.3 & & \\
624 & 99.7 & & \\
623 & 57.9 & & \\
622 & 60.5 & & \\
621 & 71.1 & & \\
620 & 91.2 & &
\end{tabular}


TABLE $A-3$

SSC \#2 TEST - TEMPERATURE DISTRIBUTION

DATE: $\quad 3 / 15 / 79$

TIME: $\quad 16: 00$

OPERATING HOURS: 2353

THERMOCOUPLE READINGS

T/C No.

654

653

652

651

650

649

648

647

646

645

644

643

642

641

640

639

638

637

636

635

634

633

632

631

630

629

628

627

626

625

624

623

622

621

620
T/C No.

70.7

78.5

93.8

70.9

76.1

86.8

111.9

69.7

73.2

82.7

102.7

71.1

64.6

80.2

93.8

66.8

75.7

89.6

112.3

65.9

72.3

84.1

104.7

63.2

67.2

77.5

93.3

65.4

71.8

88.2

110.7

64.5

70.3

81.4

101.8
683

682

681

680

679

678

677

676

675

674

673

672

671

670

669

668

667

666

665

664

663

662

661

660

659

658

657

656

655
Temp $\left({ }^{\circ} \mathrm{F}\right)$

143.3

148.7

181.6

177.0

179.5

181.4

174.0

173.3

161.7

158.6

94.5

94.5

111.3

111.7

102.9

98.3

64.0

66.4

75.5

93.4

66.4

71.7

84.0

110.8

65.0

69.5

78.8

99.0

65.5 
TABLE $A-4$

SSC \#2 TEST - TEMPERATURE DISTRIBUTION

DATE: $\quad 4 / 15 / 79$

TIME: $16: 00$

OPERATING HOURS: 3097

THERMOCOUPLE READINGS

\begin{tabular}{|c|c|c|c|}
\hline T/C No. & Temp $\left({ }^{\circ} \mathrm{F}\right)$ & I/C No. & Temp $\left({ }^{\circ} \mathrm{F}\right)$ \\
\hline $\begin{array}{l}654 \\
653 \\
652 \\
651 \\
650 \\
649 \\
648 \\
647 \\
646 \\
645 \\
644 \\
643 \\
642 \\
641 \\
640 \\
639 \\
638 \\
637 \\
636 \\
635 \\
634 \\
633 \\
632 \\
631 \\
630 \\
629 \\
628 \\
627 \\
626 \\
625 \\
624 \\
623 \\
622 \\
621 \\
620\end{array}$ & $\begin{array}{r}75.9 \\
80.6 \\
93.4 \\
96.7 \\
80.8 \\
88.4 \\
111.0 \\
97.3 \\
78.5 \\
84.6 \\
102.2 \\
75.6 \\
79.5 \\
81.3 \\
93.2 \\
84.3 \\
80.3 \\
90.4 \\
110.9 \\
83.9 \\
77.7 \\
85.4 \\
104.0 \\
75.2 \\
71.9 \\
78.8 \\
92.6 \\
80.5 \\
76.3 \\
88.6 \\
109.5 \\
80.2 \\
74.6 \\
82.5 \\
100.8\end{array}$ & $\begin{array}{l}683 \\
682 \\
681 \\
680 \\
679 \\
678 \\
677 \\
676 \\
675 \\
674 \\
673 \\
672 \\
671 \\
670 \\
669 \\
668 \\
667 \\
666 \\
665 \\
654 \\
663 \\
662 \\
661 \\
660 \\
659 \\
658 \\
657 \\
656 \\
655\end{array}$ & $\begin{array}{r}141.8 \\
146.6 \\
178.9 \\
174.5 \\
177.0 \\
178.5 \\
171.7 \\
170.8 \\
159.7 \\
157.2 \\
94.2 \\
94.1 \\
110.2 \\
110.5 \\
102.5 \\
98.2 \\
76.7 \\
71.7 \\
77.5 \\
92.8 \\
79.8 \\
76.2 \\
85.4 \\
109.5 \\
81.1 \\
74.0 \\
81.5 \\
98.5 \\
82.8\end{array}$ \\
\hline
\end{tabular}


TABLE A-5

SSC \#2 TEST - TEMPERATURE DISTRIBUTION

DATE: $5 / 14 / 79$ TIME: 20:00

OPERATING HOURS: 3793

THERMOCOUPLE READINGS

\begin{tabular}{|c|c|c|c|}
\hline T/C No. & Temp $\left({ }^{\circ} \mathrm{F}\right)$ & I/C No. & Temp $\left({ }^{\circ} \mathrm{F}\right)$ \\
\hline $\begin{array}{l}654 \\
653\end{array}$ & $\begin{array}{l}84.2 \\
87.1\end{array}$ & $\begin{array}{l}683 \\
682\end{array}$ & $\begin{array}{l}146.7 \\
151.6\end{array}$ \\
\hline 652 & 99.9 & 681 & 182.9 \\
\hline 651 & 90.0 & 680 & 178.7 \\
\hline 650 & 89.5 & 679 & 181.0 \\
\hline 649 & 94.7 & 678 & 182.9 \\
\hline 648 & 116.8 & 677 & 175.8 \\
\hline 647 & 94.6 & 678 & 174.7 \\
\hline 646 & 87.4 & 675 & 163.7 \\
\hline 645 & 91.2 & 674 & 161.5 \\
\hline 644 & 108.5 & 673 & 100.4 \\
\hline 643 & 83.5 & 672 & 100.5 \\
\hline 642 & 86.9 & 671 & 116.1 \\
\hline 641 & 88.0 & 670 & 116.7 \\
\hline 640 & 99.7 & 669 & 108.7 \\
\hline 639 & 89.8 & 668 & 104.8 \\
\hline 638 & 88.3 & 667 & 57.5 \\
\hline 637 & 96.6 & 666 & 81.5 \\
\hline 636 & 116.9 & 665 & 84.9 \\
\hline 635 & 89.2 & 664 & 99.0 \\
\hline 634 & 86.1 & 663 & 91.0 \\
\hline 633 & 92.1 & 662 & 85.8 \\
\hline 632 & 110.3 & 661 & 92.7 \\
\hline 631 & 85.0 & 660 & 116.1 \\
\hline 630 & 81.1 & 659 & 88.3 \\
\hline 629 & 85.8 & 658 & 83.1 \\
\hline 628 & 99.2 & 657 & 88.7 \\
\hline 627 & 85.4 & 656 & 105.1 \\
\hline 626 & 85.4 & 655 & 88.7 \\
\hline 625 & 95.4 & & \\
\hline 624 & 115.8 & & \\
\hline 623 & 88.2 & & \\
\hline 622 & 83.5 & & \\
\hline 627 & 89.8 & & \\
\hline 620 & 107.4 & & \\
\hline
\end{tabular}


TABLE $A-6$

SSC \#2 TEST - TEMPERATURE DISTRIBUTION

DATE: $\quad 6 / 18 / 79$

TIME: $\quad 16: 00$

OPERATING HOURS: 4633

THERMOCOUPLE READINGS

\begin{tabular}{cccc} 
T/C No. & Temp $\left({ }^{\circ} \mathrm{F}\right)$ & T/C No. & Temp $\left.{ }^{\circ} \mathrm{F}\right)$ \\
\cline { 2 - 4 } 654 & 85.2 & 683 & 159.3 \\
653 & 96.7 & 682 & 163.4 \\
652 & 113.4 & 681 & 194.3 \\
651 & 91.6 & 680 & 190.3 \\
650 & 89.2 & 679 & 192.5 \\
649 & 103.6 & 678 & 193.0 \\
648 & 129.8 & 677 & 186.6 \\
647 & 90.9 & 676 & 185.7 \\
646 & 88.0 & 675 & 174.3 \\
645 & 99.5 & 674 & 171.4 \\
644 & 120.3 & 673 & 114.8 \\
643 & 86.0 & 672 & 114.6 \\
642 & 78.1 & 671 & 130.1 \\
641 & 98.5 & 670 & 130.2 \\
640 & 113.2 & 669 & 121.1 \\
639 & 83.8 & 668 & 116.5 \\
638 & 89.2 & 667 & 77.6 \\
637 & 10.7 & 666 & 82.5 \\
636 & 130.7 & 665 & 95.7 \\
635 & 83.3 & 664 & 113.7 \\
634 & 85.6 & 663 & 80.2 \\
633 & 101.0 & 662 & 87.0 \\
632 & 122.1 & 661 & 103.0 \\
631 & 75.9 & 660 & 129.4 \\
630 & 83.2 & 659 & 81.0 \\
629 & 97.6 & 658 & 84.9 \\
628 & 113.5 & 657 & 98.7 \\
627 & 80.8 & 656 & 117.6 \\
626 & 86.9 & 655 & \\
625 & 107.5 & & \\
624 & 129.6 & & \\
623 & 80.2 & & \\
622 & 85.0 & & \\
621 & 100.1 & & \\
620 & 119.8 & &
\end{tabular}


SSC \#2 TEST - TEMPERATURE DISTRIBUTION

DATE: $\quad 7 / 15 / 79$

TIME: $16: 00$

OPERATING HOURS: 5281

THERMOCOUPLE READINGS

\begin{tabular}{cccc} 
T/C No. & Temp ( $\left.{ }^{\circ} \mathrm{F}\right)$ & T/C No. & Temp ( $\mathrm{F})$ \\
\cline { 2 - 4 } 654 & 100.5 & 683 & 164.8 \\
653 & 107.1 & 682 & 169.1 \\
652 & 120.8 & 681 & 198.9 \\
651 & 112.8 & 680 & 195.1 \\
650 & 105.2 & 679 & 197.5 \\
649 & 114.5 & 678 & 198.6 \\
648 & 137.1 & 677 & 132.0 \\
647 & 113.0 & 676 & 191.2 \\
646 & 102.8 & 675 & 179.8 \\
645 & 111.1 & 674 & 177.7 \\
644 & 128.6 & 673 & 121.8 \\
643 & 101.1 & 672 & 121.7 \\
642 & 101.3 & 671 & 137.0 \\
641 & 108.3 & 670 & 137.4 \\
640 & 120.7 & 669 & 129.4 \\
639 & 105.7 & 668 & 125.3 \\
638 & 105.1 & 667 & 99.7 \\
637 & 116.7 & 666 & 98.6 \\
636 & 137.3 & 665 & 105.8 \\
635 & 105.2 & 664 & 120.7 \\
634 & 102.6 & 663 & 102.4 \\
633 & 112.1 & 662 & 103.3 \\
632 & 130.4 & 661 & 113.4 \\
631 & 98.7 & 660 & 136.6 \\
630 & 98.8 & 659 & 104.1 \\
629 & 106.9 & 658 & 101.3 \\
628 & 120.5 & 657 & 109.6 \\
627 & 103.7 & 656 & 125.7 \\
626 & 102.9 & 655 & 102.6 \\
625 & 116.4 & & \\
624 & 136.5 & & \\
623 & 103.1 & & \\
622 & 101.7 & & \\
621 & 110.7 & & \\
620 & 128.0 & & \\
& & &
\end{tabular}


TABLE A-8

SSC \#2 TEST - TEMPERATURE DISTRIBUTION

DATE: $8 / 15 / 79$ TIME: $16: 00$

OPERATING HOURS: 6025

THERMOCOUPLE READINGS

\begin{tabular}{cccc} 
T/C No. & Temp $\left({ }^{\circ} \mathrm{F}\right)$ & T/C No. & Temp $\left({ }^{\circ} \mathrm{F}\right)$ \\
\cline { 2 - 4 } 654 & 90.6 & 683 & 157.0 \\
653 & 98.3 & 682 & 161.5 \\
652 & 113.1 & 681 & 190.6 \\
651 & 102.3 & 680 & 186.6 \\
650 & 94.8 & 679 & 188.6 \\
649 & 105.1 & 678 & 189.9 \\
648 & 128.7 & 677 & 182.6 \\
647 & 102.2 & 676 & 181.8 \\
646 & 91.8 & 675 & 170.5 \\
645 & 100.7 & 674 & 168.1 \\
644 & 119.1 & 673 & 114.1 \\
643 & 91.1 & 672 & 114.0 \\
642 & 89.7 & 671 & 128.6 \\
647 & 99.9 & 670 & 128.9 \\
640 & 113.1 & 669 & 119.9 \\
639 & 93.8 & 668 & 115.4 \\
638 & 94.8 & 667 & 88.7 \\
637 & 107.8 & 666 & 89.0 \\
636 & 128.9 & 665 & 97.4 \\
635 & 93.7 & 664 & 113.4 \\
634 & 91.4 & 663 & 91.2 \\
633 & 102.1 & 662 & 93.4 \\
632 & 120.9 & 661 & 104.5 \\
631 & 87.7 & 660 & 128.4 \\
630 & 89.5 & 659 & 91.6 \\
629 & 99.0 & 658 & 90.5 \\
628 & 113.2 & 657 & 99.9 \\
627 & 92.2 & 656 & \\
626 & $93 / 3$ & 655 & \\
625 & 104.2 & & \\
624 & 128.4 & & \\
623 & 91.5 & & \\
622 & 91.5 & & \\
621 & 101.1 & & \\
620 & 118.8 & &
\end{tabular}


TABLE $A-9$

SSC \#2 TEST - TEMPERATURE DISTRIBUTION

DATE: $\quad 9 / 15 / 79$

TIME: $\quad 16: 00$

OPERATING HOURS: 6769

THERMOCOUPLE READINGS

\begin{tabular}{cccc} 
T/C No. & Temp $\left({ }^{\circ} \mathrm{F}\right)$ & T/C No. & Temp ( $\mathrm{F})$ \\
\cline { 2 - 4 } 654 & 97.6 & 683 & 161.0 \\
653 & 105.7 & 682 & 165.1 \\
652 & 118.9 & 681 & 193.8 \\
651 & 113.4 & 680 & 189.8 \\
650 & 102.1 & 679 & 192.3 \\
549 & 112.5 & 678 & 193.5 \\
646 & 134.3 & 677 & 187.0 \\
647 & 113.8 & 676 & 186.2 \\
646 & 99.6 & 675 & 175.1 \\
645 & 109.0 & 674 & 173.1 \\
644 & 125.9 & 673 & 119.6 \\
643 & 98.1 & 672 & 119.5 \\
642 & 97.8 & 671 & 134.0 \\
641 & 106.7 & 670 & 134.3 \\
640 & 116.7 & 669 & 126.5 \\
639 & 103.3 & 668 & 122.3 \\
638 & 101.5 & 667 & 91.9 \\
637 & 114.8 & 666 & 93.4 \\
636 & 134.5 & 665 & 102.6 \\
635 & 102.7 & 664 & 118.3 \\
634 & 98.8 & 663 & 93.8 \\
633 & 110.0 & 662 & 109.6 \\
632 & 127.7 & 661 & 133.3 \\
637 & 91.3 & 660 & 94.6 \\
630 & 94.6 & 659 & 95.9 \\
679 & 104.4 & 658 & 106.0 \\
628 & 118.3 & 657 & 101.1 \\
627 & 95.8 & 656 & \\
626 & 98.1 & 655 & \\
625 & 113.4 & & \\
624 & 133.3 & & \\
623 & 95.2 & & \\
622 & 97.1 & & \\
621 & 107.4 & & \\
620 & 125.0 & & \\
& & &
\end{tabular}


TABLE A-10

SSC \#2 TEST - TEMPERATURE DISTRIBUTION

DATE: $\quad 10 / 14 / 79$

TIME: 16:00

OPERATING HOURS: 7465

THERMOCOUPLE READINGS

\begin{tabular}{|c|c|c|c|}
\hline T/C No. & Temp $\left({ }^{\circ} \mathrm{F}\right)$ & I/C No. & Temp $\left({ }^{\circ} \mathrm{F}\right)$ \\
\hline 654 & 82.5 & 683 & 146.4 \\
\hline 653 & 90.7 & 682 & 150.5 \\
\hline 652 & 104.0 & 681 & 178.8 \\
\hline 651 & 98.5 & 680 & 175.0 \\
\hline 650 & 86.4 & 679 & 177.1 \\
\hline 649 & 96.9 & 678 & 178.4 \\
\hline 648 & 118.7 & 677 & 171.6 \\
\hline 647 & 100.1 & 676 & 170.7 \\
\hline 646 & 83.7 & 675 & 160.4 \\
\hline 645 & 93.7 & 674 & 157.7 \\
\hline 644 & 110.1 & 673 & 104.9 \\
\hline 643 & 83.8 & 672 & 104.6 \\
\hline 642 & 81.1 & 671 & 118.6 \\
\hline 641 & 92.3 & 670 & 118.6 \\
\hline 640 & 103.8 & 669 & 110.6 \\
\hline 639 & 86.6 & 668 & 106.3 \\
\hline 636 & 86.9 & 667 & 76.7 \\
\hline 637 & 99.8 & 666 & 78.6 \\
\hline 636 & 119.0 & 665 & 88.2 \\
\hline 635 & 85.4 & 664 & 103.6 \\
\hline 634 & 83.8 & 663 & 78.6 \\
\hline 633 & 94.6 & 662 & 82.7 \\
\hline 632 & 111.9 & 661 & 94.6 \\
\hline 631 & 76.0 & 660 & 117.7 \\
\hline 630 & 80.0 & 659 & 78.5 \\
\hline 629 & 90.3 & 658 & 80.7 \\
\hline 628 & 103.7 & 657 & 90.8 \\
\hline 627 & 80.6 & 656 & 107.0 \\
\hline 626 & 83.4 & 655 & 84.6 \\
\hline 625 & 98.8 & & \\
\hline 624 & 117.8 & & \\
\hline 623 & 79.7 & & \\
\hline 622 & 82.1 & & \\
\hline 621 & 92.3 & & \\
\hline 620 & 109.3 & & \\
\hline
\end{tabular}


SSC \#2 TEST - TEMPERATURE DISTRIBUTION

DATE: $\quad 11 / 16 / 79$

TIME: $\quad 16: 00$

OPERATING HOURS: 8287

THERMOCOUPLE READINGS

\begin{tabular}{|c|c|c|c|}
\hline I/C No. & Temp ( $\left.{ }^{\circ} \mathrm{F}\right)$ & T/C No. & Temp $\left({ }^{\circ} \mathrm{F}\right)$ \\
\hline 654 & 67.5 & 683 & 125.8 \\
\hline 653 & 72.5 & 682 & 130.2 \\
\hline 652 & 83.6 & 681 & 158.1 \\
\hline 651 & 75.7 & 680 & 154.9 \\
\hline 650 & 71.7 & 679 & 156.9 \\
\hline 649 & 78.6 & 678 & 158.4 \\
\hline 648 & 97.7 & 677 & 152.3 \\
\hline 647 & 74.7 & 676 & 151.7 \\
\hline 646 & 69.6 & 675 & 141.7 \\
\hline 645 & 75.6 & 674 & 139.5 \\
\hline 644 & 90.5 & 673 & 84.4 \\
\hline 643 & 67.4 & 672 & 84.3 \\
\hline 642 & 67.4 & 671 & 97.6 \\
\hline 641 & 73.4 & 670 & 97.8 \\
\hline 640 & 83.4 & 669 & 90.8 \\
\hline 639 & 70.7 & 668 & 87.1 \\
\hline 638 & 70.9 & 667 & 63.4 \\
\hline 637 & 80.8 & 666 & 62.2 \\
\hline 636 & 97.9 & 665 & 68.6 \\
\hline 635 & 69.9 & 664 & 82.8 \\
\hline 634 & 68.6 & 663 & 65.1 \\
\hline 633 & 76.5 & 662 & 65.8 \\
\hline 632 & 92.7 & 661 & 74.9 \\
\hline 631 & 63.7 & 660 & 96.4 \\
\hline 630 & 63.5 & 659 & 64.4 \\
\hline 629 & .70 .5 & 658 & 64.2 \\
\hline 628 & 82.7 & 657 & 71.8 \\
\hline 627 & 66.2 & 656 & 87.2 \\
\hline 626 & 66.9 & 655 & 70.7 \\
\hline 625 & 78.6 & & \\
\hline 624 & 96.4 & & \\
\hline 623 & 65.4 & & \\
\hline 622 & 65.4 & & \\
\hline 621 & 73.2 & & \\
\hline 620 & 89.1 & & \\
\hline
\end{tabular}


TABLE $A-12$

SSC \#2 TEST - TEMPERATURE DISTRIBUTION

DATE: $\quad 12 / 15 / 79$

TIME: $\quad 16: 00$

OPERATING HOURS: 8953

THERMOCOUPLE READINGS

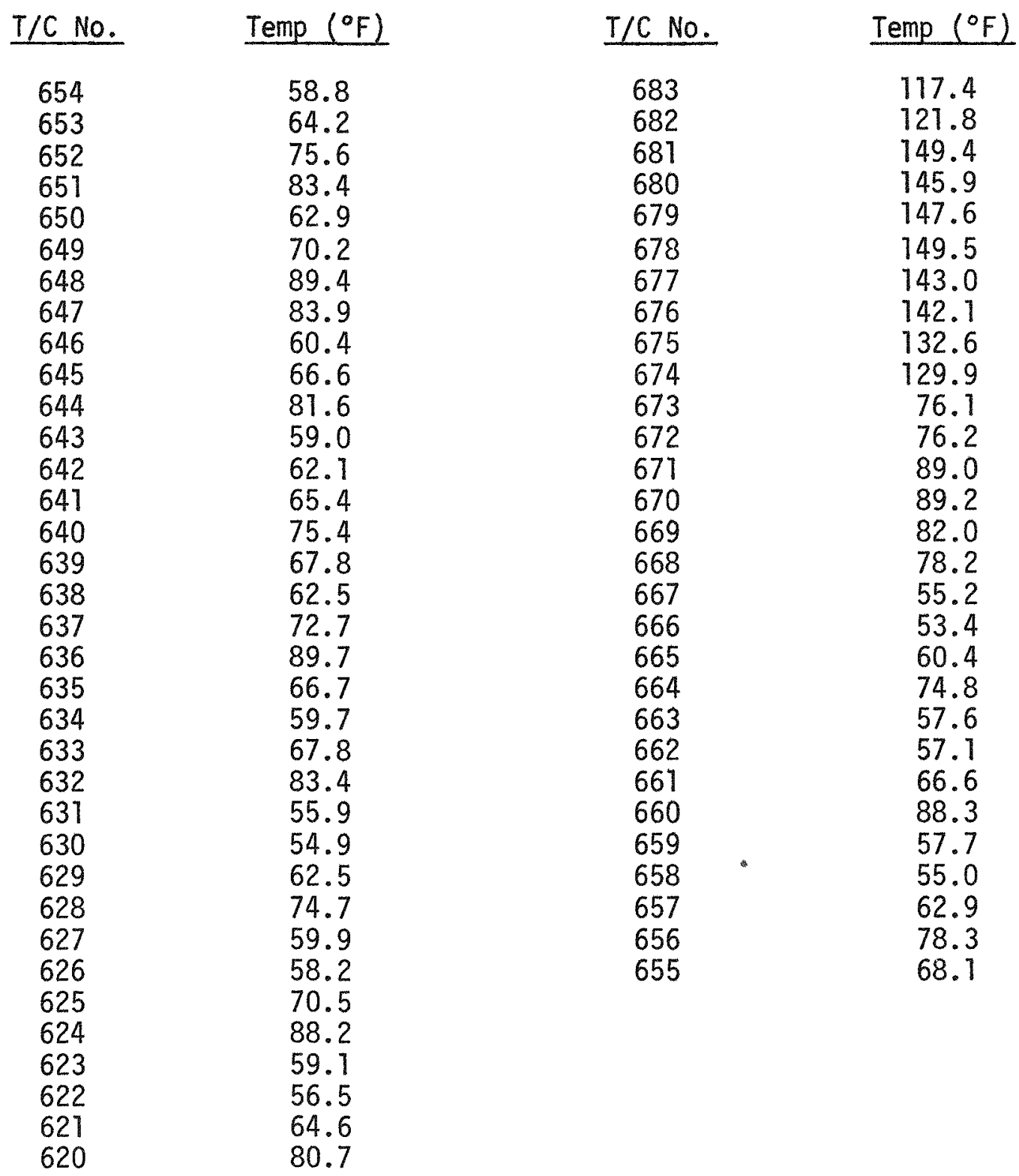


TABLE A-13

SSC \#2 TEST - TEMPERATURE DISTRIBUTION

DATE: $\quad 1 / 15 / 80$

TIME: $\quad 16: 00$

OPERATING HOURS: 9713

THERMOCOUPLE READINGS

T/C No.

Temp $\left({ }^{\circ} \mathrm{F}\right)$

T/C No.

Temp $\left({ }^{\circ} \mathrm{F}\right)$

654

56.9

683

62.1

73.7

79.4

652
651

650

649

648

647

646

645

644

643

642

641

640

639

638

637

636

635

634

633

632

631

630

629

628

627

626

625

624

623

622

621

620

60.6

67.7

87.2

80.3

58.5

64.9

80.2

57.6

59.0

63.4

73.5

64.2

61.0

70.4

87.6

63.4

58.8

66.3

82.0

55.6

56.4

62.7

73.7

59.3

59.5

70.5

87.2

59.0

58.3

65.7

80.3

115.0

119.4

146.8

143.1

145.7

147.2

141.1

139.8

130.8

127.4

74.5

74.6

87.5

87.5

81.2

77.4

55.5

55.4

61.2

73.6

57.4

58.9

67.0

87.1

57.1

57.4

64.3

78.1

64.2

656

655 
TABLE A-14

SSC \#2 TEST - TEMPERATURE DISTRIBUTION

DATE: $\quad 2 / 16 / 80$

TIME: $\quad 16: 00$

OPERATING HOURS: 10465

THERMOCOUPLE READINGS

\begin{tabular}{cccc} 
T/C No. & Temp $\left({ }^{\circ} \mathrm{F}\right)$ & T/C No. & Temp $\left.{ }^{\circ} \mathrm{F}\right)$ \\
\cline { 2 - 4 } 654 & 55.4 & 683 & 112.4 \\
653 & 60.3 & 682 & 116.8 \\
652 & 71.7 & 681 & 143.6 \\
651 & 54.4 & 680 & 140.1 \\
650 & 59.7 & 679 & 142.7 \\
649 & 66.0 & 678 & 144.1 \\
648 & 85.2 & 677 & 138.1 \\
647 & 52.8 & 676 & 136.9 \\
646 & 56.8 & 675 & 127.8 \\
645 & 62.9 & 674 & 124.5 \\
644 & 78.1 & 673 & 72.6 \\
643 & 56.0 & 672 & 72.6 \\
642 & 52.1 & 671 & 85.4 \\
641 & 61.5 & 670 & 85.6 \\
640 & 71.7 & 669 & 78.8 \\
639 & 54.0 & 668 & 75.1 \\
638 & 59.5 & 667 & 51.8 \\
637 & 68.6 & 666 & 54.1 \\
636 & 85.7 & 665 & 59.2 \\
635 & 52.8 & 664 & 71.8 \\
634 & 57.0 & 663 & 53.1 \\
633 & 64.4 & 662 & 57.7 \\
632 & 79.8 & 661 & 65.2 \\
631 & 52.1 & 660 & 85.0 \\
630 & 55.0 & 659 & 51.3 \\
629 & 60.8 & 658 & 55.9 \\
628 & 71.7 & 657 & 62.7 \\
627 & 54.0 & 656 & \\
626 & 58.2 & 655 & 51.9 \\
625 & 68.6 & 655 & 51.9 \\
624 & 85.0 & & \\
623 & 53.2 & & \\
622 & 56.8 & & \\
621 & 63.4 & & \\
620 & 78.1 & & \\
& & &
\end{tabular}


SSC \#2 TEST - TEMPERATURE DISTRIBUTION

DATE: $\quad 3 / 15 / 80$

TIME: $16: 00$

OPERATING HOURS: 11137

THERMOCOUPLE READINGS

\begin{tabular}{cccc} 
T/C No. & Temp $\left({ }^{\circ} \mathrm{F}\right)$ & T/C No. & Temp $\left({ }^{\circ} \mathrm{F}\right)$ \\
\cline { 3 - 4 } 653 & 67.2 & 683 & 115.9 \\
652 & 76.7 & 682 & 120.0 \\
651 & 82.8 & 687 & 146.5 \\
650 & 67.4 & 680 & 143.5 \\
649 & 73.0 & 679 & 145.7 \\
648 & 89.9 & 678 & 147.3 \\
647 & 82.8 & 677 & 141.4 \\
646 & 65.4 & 676 & 140.1 \\
645 & 70.2 & 675 & 131.3 \\
644 & 83.4 & 674 & 128.9 \\
643 & 62.9 & 673 & 77.2 \\
642 & 64.1 & 672 & 77.2 \\
641 & 67.6 & 671 & 89.5 \\
640 & 76.4 & 670 & 89.9 \\
639 & 68.5 & 669 & 83.7 \\
638 & 66.3 & 668 & 80.4 \\
637 & 74.6 & 667 & 61.5 \\
636 & 89.9 & 666 & 58.7 \\
635 & 68.2 & 665 & 63.5 \\
634 & 64.4 & 664 & 75.7 \\
633 & 70.9 & 663 & 64.1 \\
632 & 84.9 & 662 & 62.3 \\
631 & 60.6 & 661 & 69.6 \\
630 & 59.4 & 660 & 88.6 \\
629 & 64.7 & 659 & 65.6 \\
628 & 75.6 & 658 & 60.8 \\
627 & 65.6 & 657 & 80.3 \\
626 & 62.8 & 656 & 68.2 \\
625 & 72.5 & 655 & \\
624 & 88.6 & 654 & \\
623 & 65.6 & & \\
622 & 61.6 & & \\
621 & 67.9 & & \\
620 & 82.4 & & \\
& & &
\end{tabular}


TABLE A-16

SSC \#2 TEST - TEMPERATURE DISTRIBUTION

DATE: $4 / 15 / 80$

TIME: $\quad 16: 00$

OPERATING HOURS: 11881

THERMOCOUPLE READINGS

\begin{tabular}{|c|c|c|c|}
\hline I/C No. & Temp $\left({ }^{\circ} \mathrm{F}\right)$ & I/C No. & Temp $\left({ }^{\circ} \mathrm{F}\right)$ \\
\hline 653 & 77.6 & 683 & 125.9 \\
\hline 652 & 87.2 & 682 & 129.5 \\
\hline 657 & 97.0 & 681 & 155.7 \\
\hline 650 & 77.7 & 680 & 152.3 \\
\hline 649 & 83.6 & 679 & 154.9 \\
\hline 648 & 100.8 & 678 & 156.1 \\
\hline 647 & 96.5 & 677 & 150.5 \\
\hline 646 & 75.8 & 676 & 149.2 \\
\hline 645 & 80.8 & 675 & 140.4 \\
\hline 644 & 93.9 & 674 & 138.0 \\
\hline 643 & 73.3 & 673 & 88.2 \\
\hline 642 & 79.4 & 672 & 88.0 \\
\hline 641 & 78.0 & 671 & 100.5 \\
\hline 640 & 86.8 & 670 & 100.7 \\
\hline 639 & 85.5 & 669 & 94.6 \\
\hline 638 & 77.0 & 668 & 91.2 \\
\hline 637 & 85.2 & 667 & 75.2 \\
\hline 636 & 100.6 & 666 & 69.3 \\
\hline 635 & 85.6 & 665 & 74.5 \\
\hline 634 & 75.2 & 664 & 86.4 \\
\hline 633 & 81.4 & 663 & 78.9 \\
\hline 632 & 95.4 & 662 & 72.9 \\
\hline 631 & 73.5 & 661 & 80.8 \\
\hline 630 & 69.5 & 660 & 99.3 \\
\hline 629 & 75.6 & 659 & 80.5 \\
\hline 628 & 86.2 & 658 & 71.5 \\
\hline 627 & 79.5 & 657 & 77.8 \\
\hline 626 & 73.2 & 656 & 91.0 \\
\hline 625 & 83.3 & 655 & 83.7 \\
\hline 624 & 99.4 & 654 & 73.7 \\
\hline 623 & 79.6 & & \\
\hline 622 & 72.1 & & \\
\hline 621 & 78.7 & & \\
\hline 620 & 92.8 & & \\
\hline
\end{tabular}




\section{APPENDIX B}

TAP-A INPUT AND OUTPUT

This Appendix contains a copy of typical computer printout of the TAP-A input data and printouts of the output data for the times listed. The nodes are identified and their locations are shown in Figure 27. For an explanation of the input data and its format, see Reference 4.

\section{Temperature Calculations}

Seconds*

$.130 E 07$

.389507

$.648 E 07$

$.907 \mathrm{E} 07$

$.117 \mathrm{E} 08$

$.143 E 08$

$.168 E 08$

$.194 E 08$

$.220 E 08$

$.246 E 08$

$.272 \mathrm{E} 08$

$.298 E 08$

$.324 E 08$

$.350 E 08$

$.376 \mathrm{E} 08$

.402 E08
Equivalent Operating Hours

946

1668

2388

3104

3835

4557

5252

5974

6696

7418

8140

8862

9585

10307

11029

11752
Date

$1 / 15 / 79$

2/14/79

$3 / 15 / 79$

4/14/79

$5 / 14 / 79$

$6 / 13 / 79$

$7 / 13 / 79$

$8 / 12 / 79$

$9 / 71 / 79$

10/11/79

$11 / 10 / 79$

$12 / 10 / 79$

$1 / 10 / 80$

$2 / 9 / 80$

$3 / 9 / 80$

$4 / 8 / 80$

* January 1, 1979 is zero time for printouts of output data. 
IAP-ITHANSIENT ANALYSIS PHUSRAM

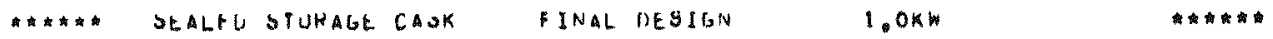

SPECTPILAIIUNS

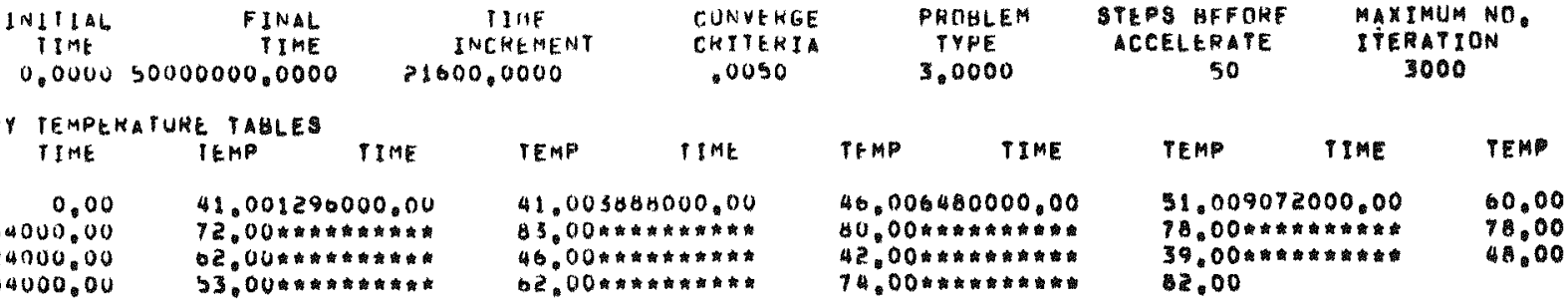

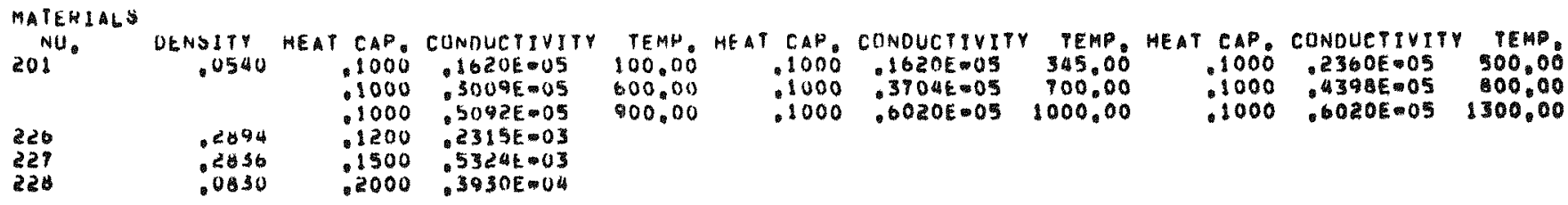

INIERNAL HEAT GENERATIUN MULTIPLTEN TABLES

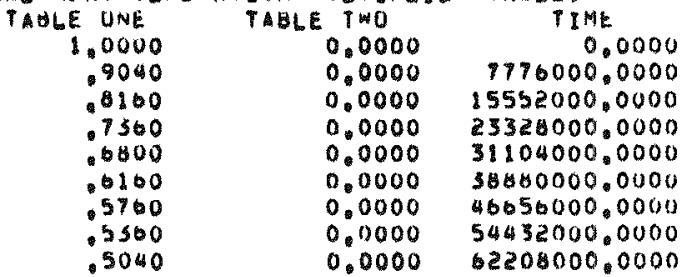

INTEKN NOLES

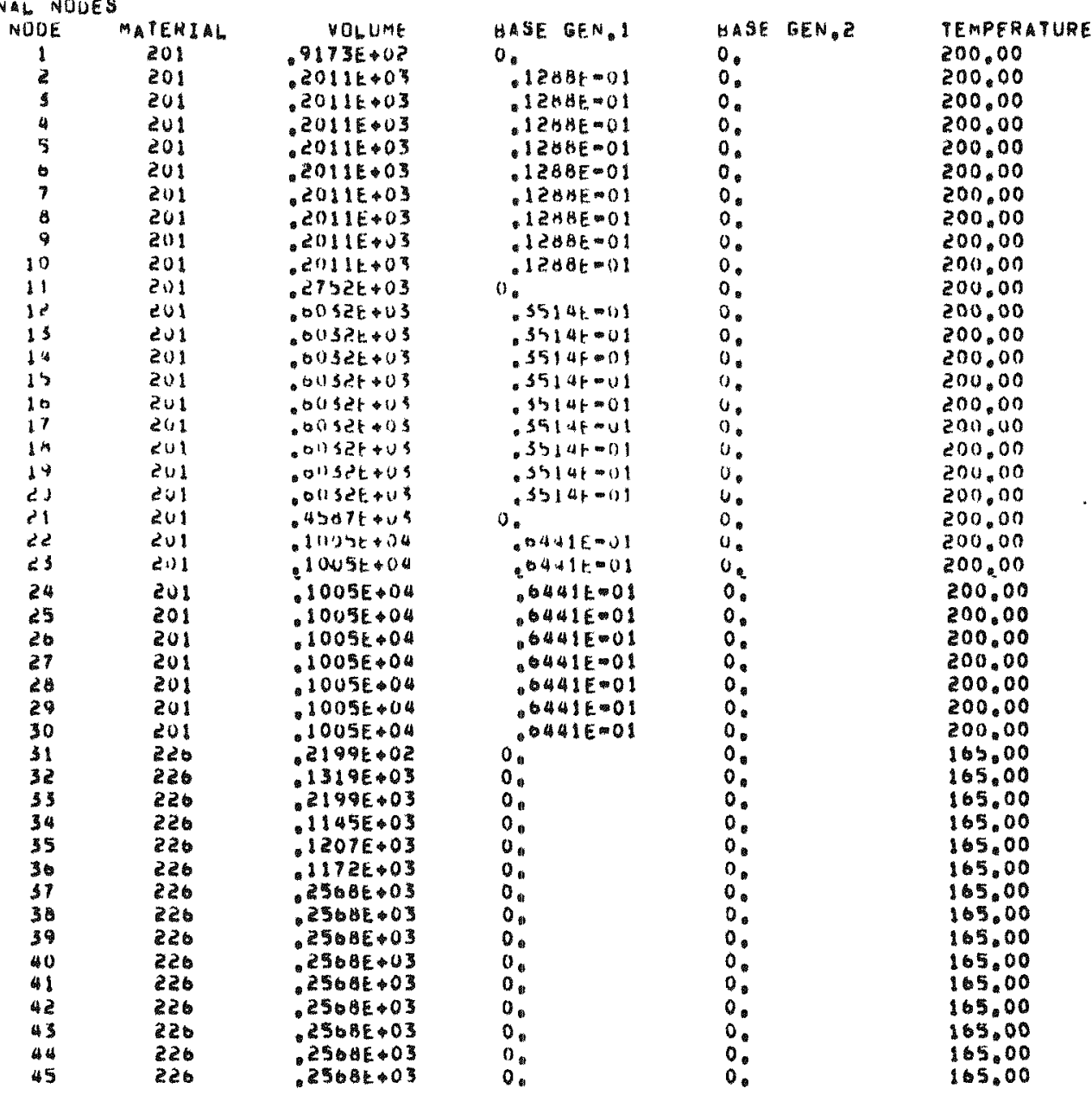


TAP-A INPUT (Cont'd)

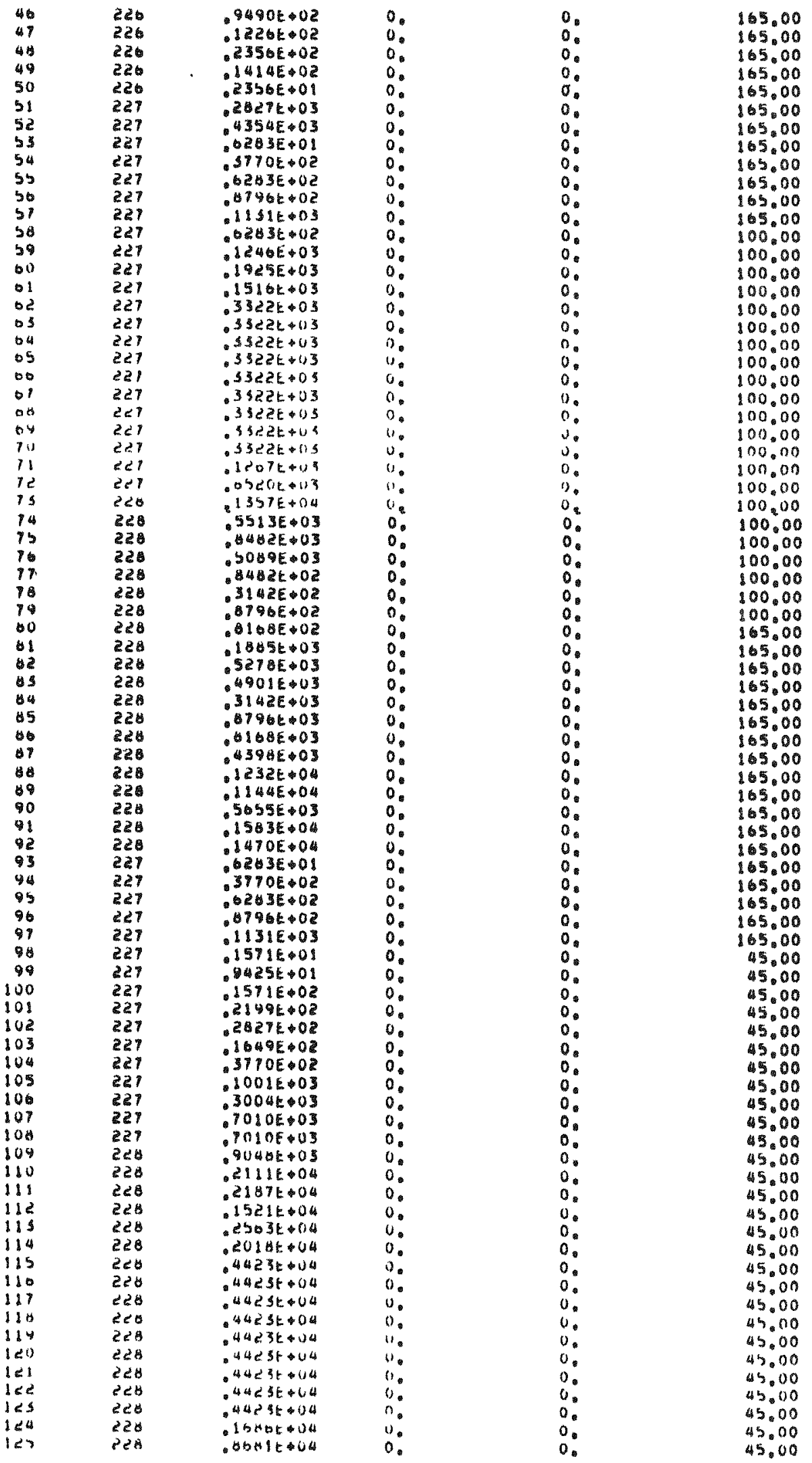


TAP $-A$ INPUT (Cont' $d$ )

\begin{tabular}{|c|c|c|c|c|c|}
\hline 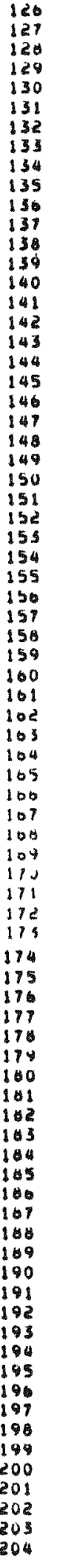 & $\begin{array}{l}228 \\
228 \\
228 \\
228 \\
228 \\
228 \\
228 \\
228 \\
228 \\
228 \\
228 \\
228 \\
228 \\
228 \\
228 \\
228 \\
228 \\
228 \\
228 \\
228 \\
228 \\
228 \\
228 \\
228 \\
228 \\
228 \\
228 \\
228 \\
228 \\
228 \\
228 \\
228 \\
228 \\
228 \\
228 \\
228 \\
228 \\
228 \\
228 \\
228 \\
228 \\
228 \\
228 \\
228 \\
228 \\
228 \\
228 \\
228 \\
228 \\
228 \\
228 \\
228 \\
228 \\
228 \\
228 \\
228 \\
228 \\
228 \\
228 \\
228 \\
228 \\
228 \\
228 \\
228 \\
228 \\
228 \\
228 \\
228 \\
228 \\
228 \\
228 \\
228 \\
228 \\
228 \\
228 \\
228 \\
228 \\
228 \\
228\end{array}$ & 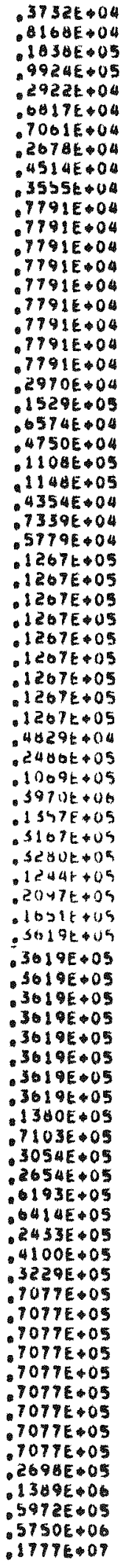 & 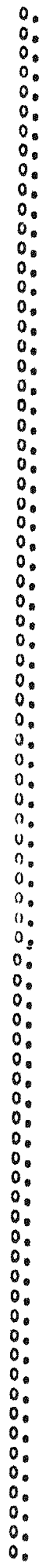 & 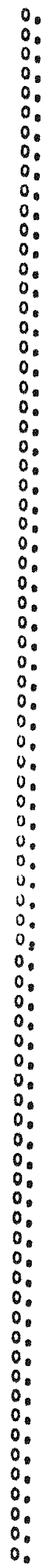 & 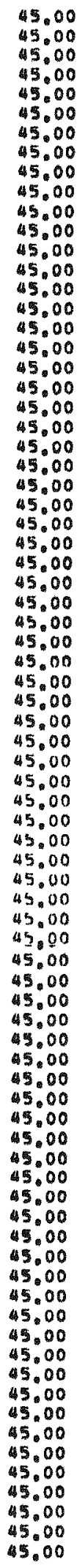 \\
\hline
\end{tabular}


TAP-A INPUT (Cont'd)

INTEHNAL AOMITTANCES

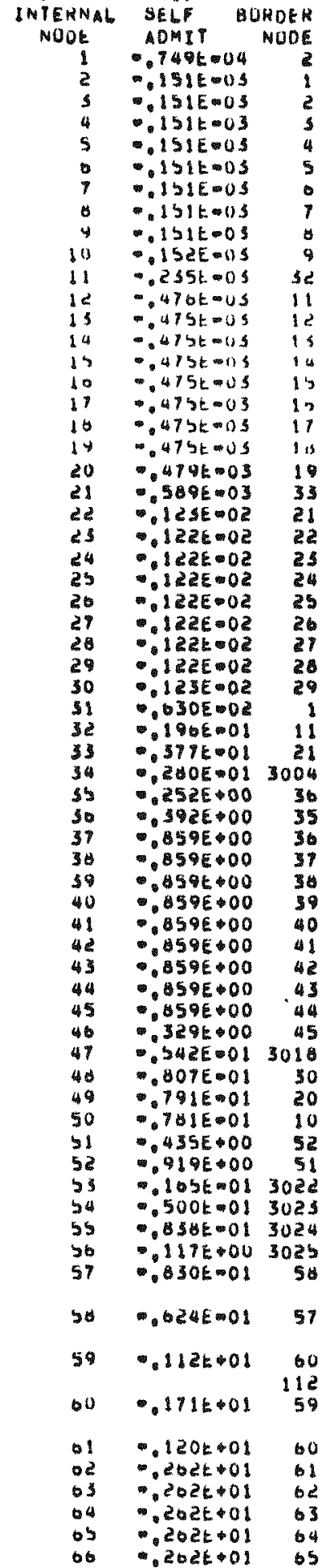

\begin{tabular}{|c|c|c|c|}
\hline \multicolumn{2}{|c|}{ BORDER } & \multicolumn{2}{|c|}{ BUROEK } \\
\hline 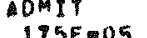 & & ADMIT & NODE \\
\hline $\begin{array}{l}.875 E-05 \\
175 F .05\end{array}$ & 31 & $\begin{array}{l}.550 E-05 \\
127 E-05\end{array}$ & $\begin{array}{l}11 \\
12\end{array}$ \\
\hline $127 \mathrm{E}=05$ & 4 & : $127 E-05$ & 13 \\
\hline $121 E=05$ & 5 & $.127 t=05$ & 14 \\
\hline $.127 f \mathrm{Fos}$ & 6 & . $127 E 005$ & 15 \\
\hline $.127 E=05$ & 8 & 127E-05 & 16 \\
\hline .127600 & 8 & $.127 E-05$ & 17 \\
\hline Q127t-0b & 9 & D27E-05 & 18 \\
\hline $.127 F-03$ & 10) & $.127 E-05$ & 19 \\
\hline $127 t-0 s$ & so & ES4E-US & 20 \\
\hline $.16 / E-0.4$ & 12 & $.5246-05$ & 1 \\
\hline .5745005 & 13 & 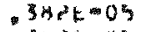 & $z^{2}$ \\
\hline$=38<E-1) 4$ & 14 & 360503 & 3 \\
\hline SHCF $=5$ & 15 & $.9826=04$ & 4 \\
\hline . $3 x+5=13$ & 10 & $.31 S 2 E=04$ & 5 \\
\hline - $5 \mathrm{H} P \mathrm{O}-\mathrm{OS}$ & 17 & $.368 k=05$ & 0 \\
\hline . 34 et $=195$ & 19 & $.3152 t-05$ & 8 \\
\hline $.98 e^{2}=05$ & 19 & $3 n+k-155$ & $a$ \\
\hline . 5 Het $=05$ & (1) & $.302 E=05$ & 9 \\
\hline $.3 B E E-05$ & 49 & $.763 E=05$ & 10 \\
\hline $\begin{array}{r}270 t=04 \\
77 E=05\end{array}$ & $\begin{array}{l}22 \\
23\end{array}$ & $\begin{array}{r}.74 E=05 \\
630 E \text { OS }\end{array}$ & 11 \\
\hline $301=05$ & 24 & $.36 E=05$ & 13 \\
\hline $.30 E=05$ & 25 & $.636 E$ ES & 18 \\
\hline .305005 & 26 & $.030 E=05$ & 15 \\
\hline $.360-05$ & 27 & $.36 E 005$ & 16 \\
\hline $\begin{array}{r}630 E-05 \\
030 E-05\end{array}$ & $\begin{array}{l}28 \\
29\end{array}$ & $\begin{array}{r}636 E=05 \\
036 E=05\end{array}$ & 8 \\
\hline $.30 \mathrm{c} 05$ & 30 & $.656 E$ O5 & 19 \\
\hline $.636 E-05$ & 48 & 12TEW04 & 20 \\
\hline $.556 \mathrm{t}-05$ & $\begin{array}{l}3001 \\
3002\end{array}$ & .1665002 & 32 \\
\hline $\begin{array}{l}.1675-04 \\
276 t=04\end{array}$ & $\begin{array}{l}3002 \\
3003\end{array}$ & $\begin{array}{r}499 E=02 \\
\text { BIEDOZ }\end{array}$ & 31 \\
\hline $.540 E$ DOZ & $\$ 3$ & $.194 E=01$ & 35 \\
\hline $.448 E=03$ & 34 & $.388 E=0 Z$ & 32 \\
\hline $.440 E=05$ & 37 & $.318 E 005$ & 3007 \\
\hline $.319 t=03$ & 38 & $.2325=03$ & 3008 \\
\hline-232803 & 39 & ESEED05 & $300 \%$ \\
\hline $\begin{array}{r}232 E-03 \\
.232 E .03\end{array}$ & $\begin{array}{l}40 \\
41\end{array}$ & $\begin{array}{r}.232 E .03 \\
.232 E 003\end{array}$ & 3011 \\
\hline $.232 E \div 03$ & 42 & $232 E \div 03$ & 3012 \\
\hline .2326003 & 43 & $.252 E-03$ & 3013 \\
\hline $.232 E=03$ & 44 & $.232 E \times 03$ & 3014 \\
\hline$-2326=03$ & 45 & .2325003 & 3015 \\
\hline $\begin{array}{l}232 E=03 \\
336 E=05\end{array}$ & $\begin{array}{r}46 \\
3018\end{array}$ & $\begin{array}{r}336 t=03 \\
3275+00\end{array}$ & 3016 \\
\hline $\begin{array}{r}336 E 005 \\
504 E-01\end{array}$ & $\begin{array}{r}3017 \\
46\end{array}$ & $\begin{array}{r}327 E+00 \\
165 E 02\end{array}$ & $\begin{array}{l}47 \\
48\end{array}$ \\
\hline .1276004 & 3019 & $.776 E=01$ & 47 \\
\hline .7038 .05 & 3020 & $.776 E-01$ & 48 \\
\hline & $302 !$ & DEDOI & 19 \\
\hline $\begin{array}{r}329 E-02 \\
329 E-02\end{array}$ & $\begin{array}{l}3005 \\
3006\end{array}$ & $\begin{array}{r}311 E \div 00 \\
481 E \div 00\end{array}$ & $\begin{array}{l}59 \\
55\end{array}$ \\
\hline .1345001 & 60 & $.755 E=04$ & 54 \\
\hline .4015001 & 83 & .2278003 & 53 \\
\hline $.069 \mathrm{k}=01$ & $\$ 6$ & $.37 \triangle E=03$ & 54 \\
\hline $.937+001$ & 69 & $.529 \mathrm{EDO} 03$ & 55 \\
\hline $.424 E 001$ & 92 & .6805003 & 59 \\
\hline - 424E-01 & 100 & $.308 E=02$ & 112 \\
\hline $.1645-02$ & 57 & $.316 E=02$ & 3020 \\
\hline $\begin{array}{l}.72 E=02 \\
1 B 4 E * C 2\end{array}$ & 61 & $.133 t=02$ & 3027 \\
\hline$E=0 e^{2}$ & & & 36 \\
\hline$E=03$ & 03 & $: 091 t=03$ & 3024 \\
\hline $.091 F=03$ & 64 & $.091 E=03$ & 3030 \\
\hline $.0915=03$ & 65 & $.691 E=03$ & 3031 \\
\hline .0911 & 00 & $.691 E 003$ & 3032 \\
\hline $.091 \mathrm{E}=03$ & 07 & $.691 E=03$ & 3033 \\
\hline
\end{tabular}

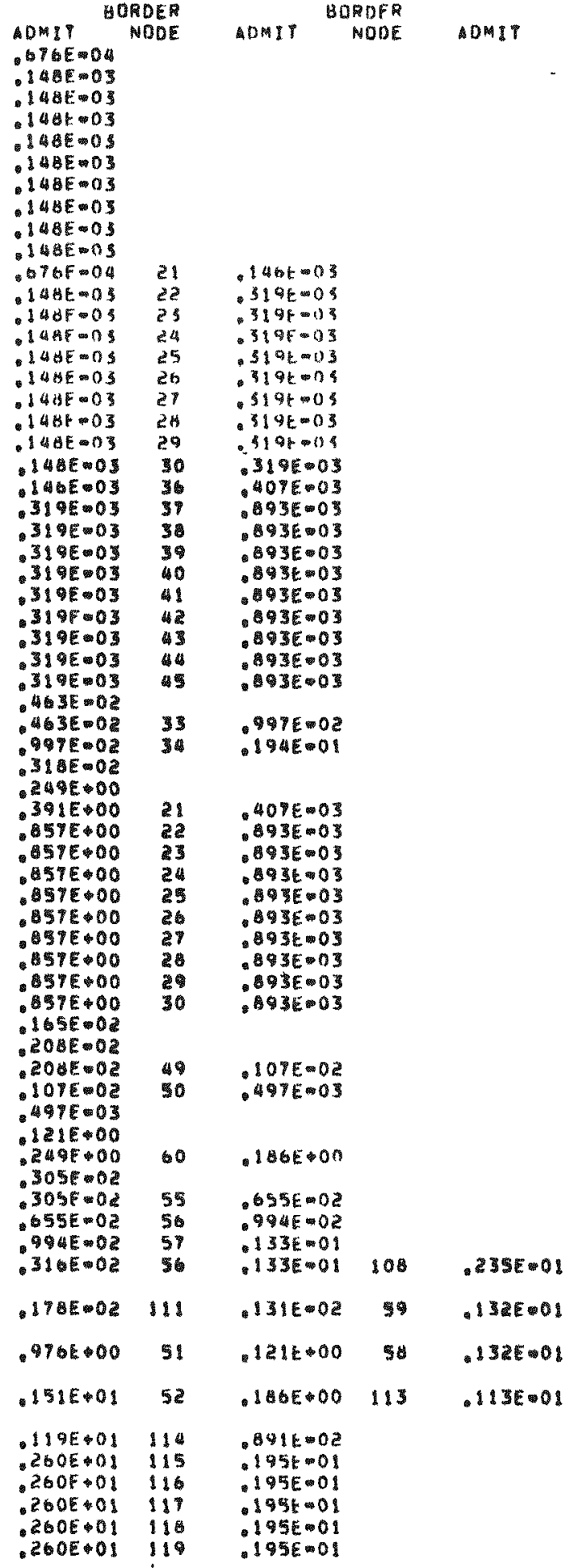


TAP-A INPUT (Cont'd)

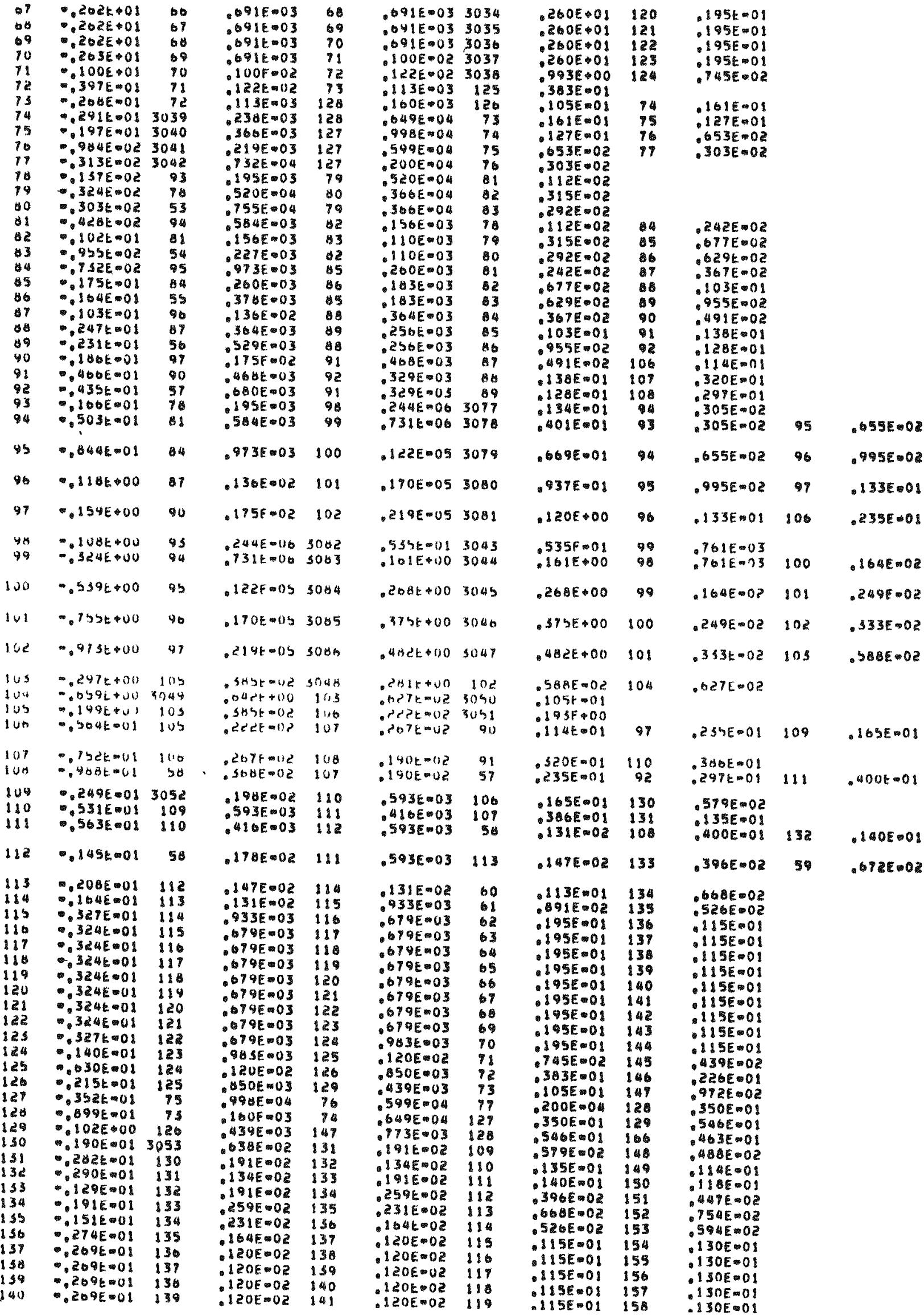


TAP-A INPUT (Cont'd)

\begin{tabular}{|c|c|c|}
\hline 141 & $.209 t-01$ & 100 \\
\hline $14 e^{2}$ & $91-01$ & $1 * 1$ \\
\hline 45 & 95. 01 & 142 \\
\hline 44 & -01 & 145 \\
\hline 45 & $2 \xi-01$ & 144 \\
\hline 40 & $\Delta \varepsilon=01$ & $14 b$ \\
\hline 47 & $0 E \div 01$ & 140 \\
\hline 140 & $5 E \approx 01$ & 3054 \\
\hline 49 & $3 E=0 !$ & 140 \\
\hline so & $=01$ & 149 \\
\hline 121 & $5 E-01$ & 150 \\
\hline 152 & 90001 & 151 \\
\hline 153 & 48001 & 152 \\
\hline 154 & $1 E 001$ & 153 \\
\hline 155 & 106001 & 154 \\
\hline 50 & OE 01 & 153 \\
\hline 157 & OEDOI & 150 \\
\hline 34 & & 157 \\
\hline 134 & & $\begin{array}{l}15 \% \\
159\end{array}$ \\
\hline 101 & $0 E 01$ & 160 \\
\hline 62 & 9601 & 101 \\
\hline 03 & 340001 & 162 \\
\hline 04 & $1 E-01$ & 163 \\
\hline 165 & $O E=O 1$ & 104 \\
\hline 106 & $7=00$ & 165 \\
\hline 107 & E 01 & 3055 \\
\hline 10 & & 167 \\
\hline 190 & $1=08$ & 109 \\
\hline 71 & $2 E 001$ & 170 \\
\hline 72 & 15008 & 171 \\
\hline 13 & $6 E 01$ & 112 \\
\hline 75 & $5 E \neq 0$ & 178 \\
\hline 75 & $5 E=01$ & 194 \\
\hline 1 & $5=01$ & 175 \\
\hline 177 & 5.00 & 170 \\
\hline 170 & $E=1$ & 178 \\
\hline 179 & $5 E-01$ & 170 \\
\hline 160 & $E \geqslant 01$ & 119 \\
\hline 101 & 001 & 180 \\
\hline 182 & 001 & 181 \\
\hline $\begin{array}{l}103 \\
185\end{array}$ & & $\begin{array}{l}102 \\
103\end{array}$ \\
\hline 115 & 1601 & 3050 \\
\hline 10 & & 185 \\
\hline 107 & 1201 & 100 \\
\hline 100 & QE 01 & 187 \\
\hline is & 1 & 188 \\
\hline 180 & $4 E 00$ & 109 \\
\hline 191 & $\theta k-1$ & 190 \\
\hline 192 & $7 \mathrm{t} * 0 \mathrm{I}$ & 191 \\
\hline 145 & $1 E=01$ & 192 \\
\hline 194 & $E-01$ & 195 \\
\hline 142 & $1 t=01$ & 194 \\
\hline 190 & $7 E-01$ & 195 \\
\hline $1 \geqslant 1$ & $7 t-01$ & 190 \\
\hline 190 & $7 \mathrm{k}=1$ & 197 \\
\hline 199 & $606 t=01$ & 180 \\
\hline , & $\Delta t=01$ & 199 \\
\hline 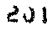 & $94 t-01$ & 200 \\
\hline 1) 2 & $49 t=01$ & 201 \\
\hline & $147 t 000$ & 2012 \\
\hline 04 & $26 t \propto 00$ & 78 \\
\hline
\end{tabular}

$.0204=02 \quad 142$

$.120 f-02 \quad 143$

- deotroz las

- 12utola las

- 115toz 146

. EIIE-02 149

150E 02129

.josenol 149

- 311E-0z 150

- $215 E$ ar 131

उ04E-02 152

- 425E-02 153

- STOE-0E 154

-267E-02 125

1 $44 E 02 \quad 156$

194E-02 157

- 19uenul 158

- 194E-0z 159

194E-02 101

$194 E-02$
.102

.194 EDOZ 105

- 28 EE 0 OE 100

$.343 t .02 \quad 105$

-za3e-0z 160

- 20 E 02 la

-29belol 108

.689E-02 168

- $13 E=02 \quad 170$

$067 \mathrm{EO} \quad 171$

- 120r-01 ir

- 107E-01 173

. $758002 \quad 174$

$.556 E$ OZ 175

55OEDOZ 176

.550t-02 117

.550E-02 170

.550E.02 110

- 556E.0z 100

.55OE 02 181

$.556 e-02$ la

- Bo4e-0z los

.979E-0z isa

.696E 160

.5795001 do

$1746=01$ 137

120E-01 188

190E.01 180

.235E-01 190

-210F-01 191

- 144t-0I lue

10YE 01 193

.207501 190

- 109eor las

-1U4E-01 296

$.109501 \quad 147$

$104501 \quad 148$

jogk-01 190

- 1045-01 200

. 157t-ur zus

- dolr-0l zue

- 13at-ui zus

- JOz-Uz 106
$. j 20 z-0 z \quad 1 z 0$ $.120 \mathrm{0}-121$ - 1zoenoz laz . 1) je-0z lez - EIIE-02 124 $150 E 02 \quad 125$ .773E-0 120 - jae-0z 130 - ISE 304E UV I3E - aciendz I3 -376t-02 134 - $261 E 0202$ IS5 - 194EDE 130 $194 E 002 \quad 13 \%$ - d94E.0z I3E -194E-02 \$39 $.194 E 0.02 \quad 140$ $194 E 02 \quad 148$ 194ED0Z IUZ $.19 a E-02$ ias - 282E:02 144 . उ43E-02 145 - $243 E=02 \quad 146$ 1 zOE.0Z 147 $.3592002 \quad 129$ - Bagevor la . Bo7e.0e 150 120k-01 151 . Jo7Emol isa $.763 E 02 \quad 153$ $5565002 \quad 154$ $.5560=02 \quad 155$ $.550 E 002 \quad 150$ $.556 \mathrm{E}-02 \quad 157$ -550E-0C 158 .550 E 02100 -556Em0z 161 - BouEtoz 162 - 79 EDoz 163 $.096 E=02 \quad 164$ $.359 E-02 \quad 165$ - 174E-01 167 - DzOE-0I 160 - 17OE-0I 169 .235500180 .210E-0I ITI - 149E-01 172 109e-01 l7a $.109 E-01 \quad 175$ . 109E-01 176 - DOQEOOL 177 100E-01 17\% $.100601 \quad 179$ - 100E 180 .157E-151 181 - Mle-ul 102 - Dotoul laz . Tuetroe ina - hr7k-ul 204
.0156001 150

115E0 160

- 125E-01 101

- d15E-101 862

- $439 E=02103$

-2ZOE 01 104

972E.02 165

- 486E-0द 167

- 114EDO 168

1LOEDI 160

GUYE $02 \quad 170$

$.754 E=02 \quad 111$

5945002 192

130E 173

$150 E-01$ 17

I3OE 101

- ISOE-OS IT

- boenar it

\$3OE-O1 19

130E.01

$1300_{01} 100$

I305001 IE

496E-02 182

255E-01 103

$110 E 0128$

- 463 E.

- $15 E-02$ IOS

$969 E 02136$

$100 E 01$

उBIE:0z IAS

$642 E 0 \% 109$

505E-02 100

HHE-01 19

1IIE⿵os 19

IIIC 01

- HIEDOS 190

- 118E00 195

IIIE-OL 196

111E001 197

- diecos 10

- HIEEOL 100

- $42 z$ E. 02

zire-01 201

935E-02 202

उAYE 02 505\%

$903 E 02305$

935 E. 023059

355 E. 023000

-508E-02 3061

- $471 E 02306$

- J03E-01 3063

103E0 506

- DOSEEOL 3065

- DO3E 0l 3006

. 103E-01 506\%

. $103 E-013068$

. DOSEOLI 3069

- IOSEDOL 3070

- 103E OI SOY

$393 k=023072$

z0zए 013075

- Hrot-0z sor

$.7378=01$

$.15 e^{5} 00$
- SOE OI

$130 t-01$

- 1 SOEDOI

- $130 E=01$

- 486E-02

255k 01

- II OE 01

- $15 E-02$

- 89E 02

100E 01

- 381502

642E 0 2

$.505 E-02$

111E-0I

1 1200

- IIE OO

- IIE OO

- IIEOOS

IIE-OI

- 11800

- dienos

- 111E-01

- M22E-0Z

- 1 IE 01

- 95E 02

- 67 V 01

- 587E 02

$.03 E 02$

$.95 \mathrm{E} 02$

- 355E.02

-598r-0e

- $471 E-02$

D $03 E=01$

- 03 EDOI

- 103 E 01

- $103 E$ EO

10SEDO

-103E 01

$.103 E-01$

- $103 E$ EO

- $103 E 01$

393E 02

- ZOEE-0I

- BTOE 02

- 887E-0Z

207E-01

- 21 AE 01

- BI 3E.02

- ITEDOL

- $108 \mathrm{E}$.08

-237E-01

-237E-01

-23PE- 01

- $257 E 01$

- $37 E-01$

- 37501

- 2STE-OI

? 3 TEOI

$.237 t=01$

- oner 0 e

- 464001

$.200 E-01$ 
TAP-A INPUT (Cont'd)

INTERIAL CIJNTACT CUNDUCTANCES

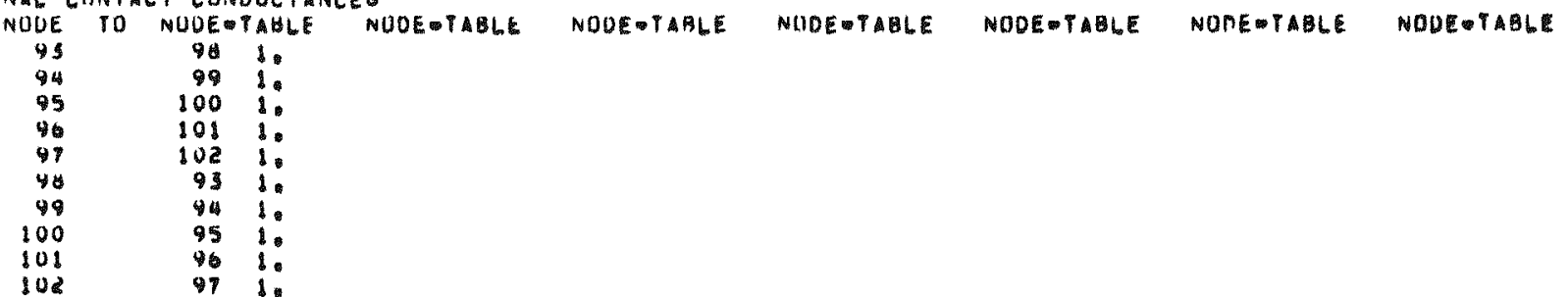

FORCEO CONYECIION,GAS CUNOUCTIVITY UR CONTAGT CONOUCTANCE TABLES

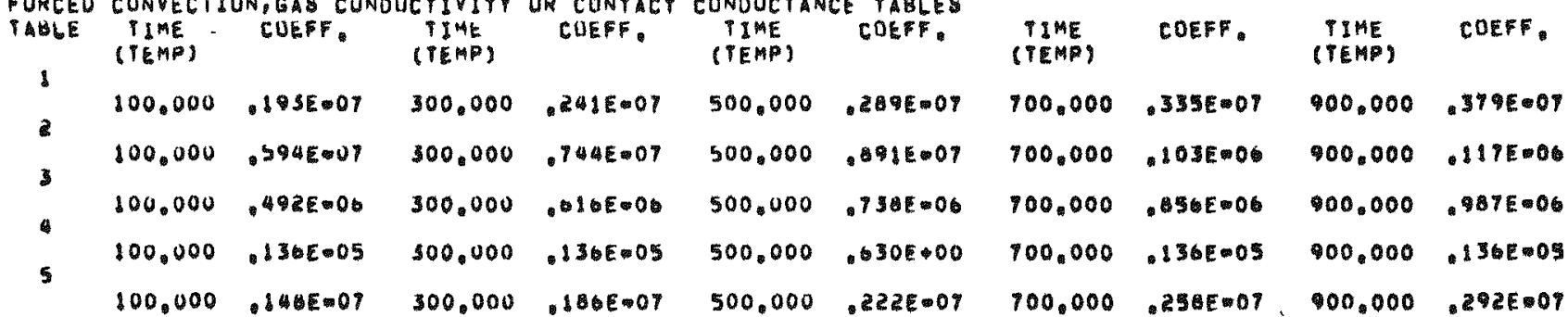

SURFACE TO BOUNDAKY CUNAECTOHS

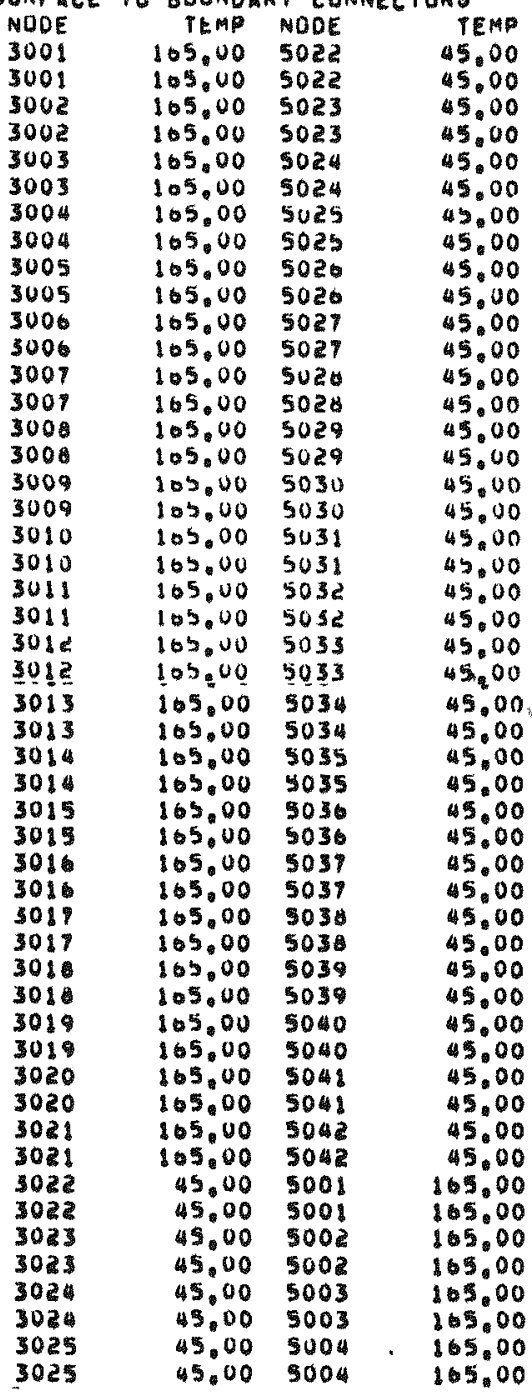

MECHANISM

RADIATION CUNAECT CONDUET THRU GAP KADIAYION CUNNECT CONDUCT. THRU GAP MADIATION CDNNECT CONDUCT. THRI GAP RADIATION CUNNET CONDUCT, THRU GAF RADIATIUN CONNECT CUNDUCT THRU GAP R DIATION CUNAECT CUNDUCT THWU GAP RODIATION CONNECT CUNDIICT THGU GAP QADIATION CONNECI CONDUCT THRII GAP HAUIATIUN CUNNECT CLNDUCT THEL GAP HAGIATJUN CUNAEC CONUUCT THKU SAP RAOLAYTUE CUNAECT CUNOUCT THER GAP RADIATIUN CUNNECI CUNOUCP THAU GAP RADIAIION CUNAECT CONDUCP THRU GA RAOIATION CONAECT CONDUCT THEU GA RADIATIUN CONNECT CONDUCT. THRU GAF RADIATION CONNECT CONOUCT TMHU GAP RADIATIUN CONAECT CONDUCT. THRU GA RADIATION CONNECT CONDUCT, THRU GA RAOIATION CONAEC CONDUCP. THAU GAP RADIATION CONNECT CONDUCT THRU GAP HOIATION CONNEC CONDLCT PMRU GAP RADIATION CONNECT CUNOUET THRU GAP ROIATION CONNECT CONDUCP THRU GAP RAOIATIUN CONNECT CONDUCT THOU OA

MOI TION CONNECI CONDUCT. THMU GAP

\begin{tabular}{|c|c|}
\hline 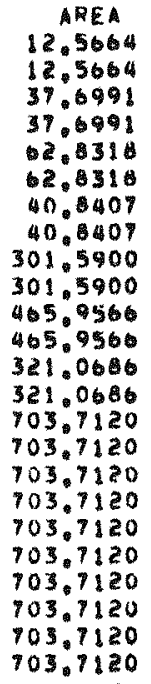 & 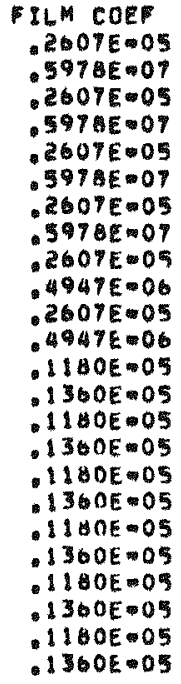 \\
\hline 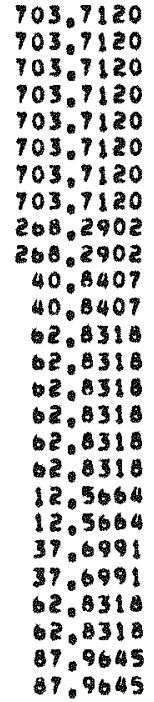 & 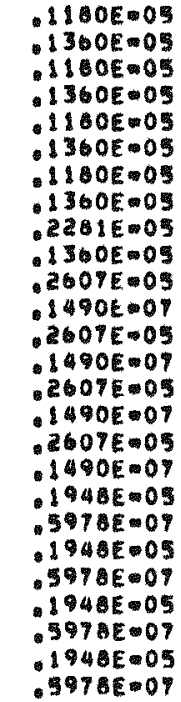 \\
\hline
\end{tabular}

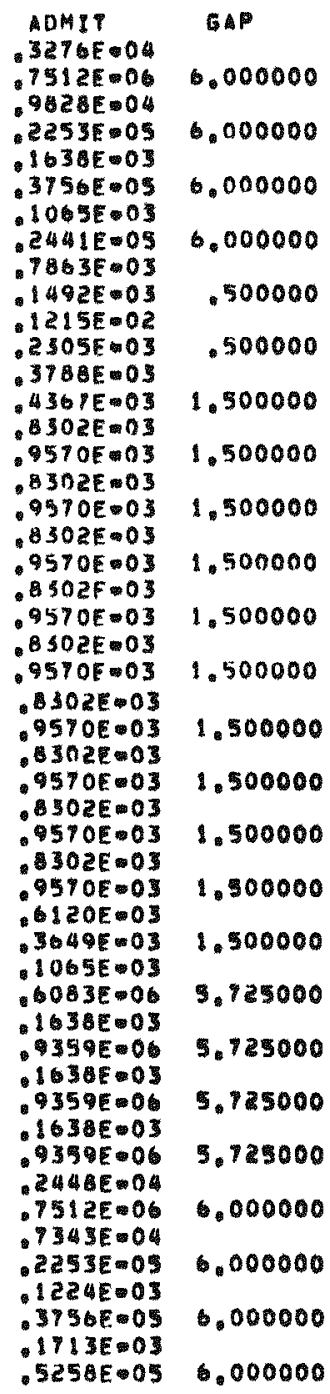


TAP-A INPUT (Cont'd)

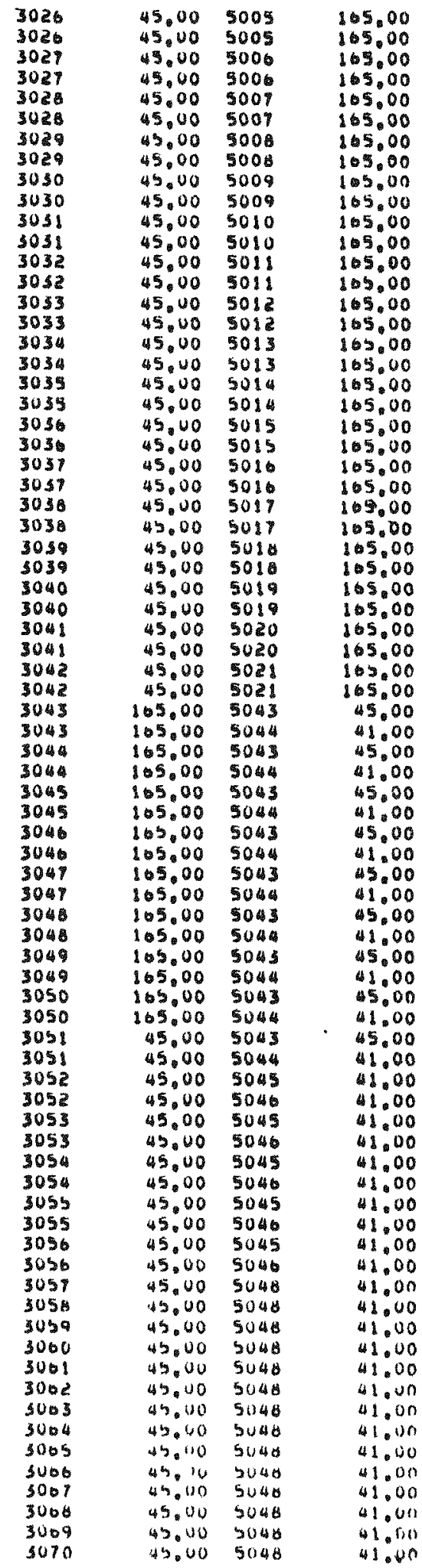

RAOZATION CONNECT CONOUCT. THAU GAP TADIATION CONAECT CONDUCY. THAU GA RAOIATION CONNECY CONOUCY. THRU GA RADIATION CUNAECT CONDUCP. THAU GAP RADIATIUN CUNAECT CONDUCT. THRII GA RADIAIIÓN CUNAECT CONDUCT. THAU GAP *ADIATION CUNAECT CONDUCT THAL GAP RADIATION CONNECT CONDUCT, THAU GA RADIATION CUNAECT CDNOUCT THAU GAP HAOIATIUN CONAECT CUNDUCY, THRU GAP KADIATION CONNECT CONDUCT. THEU GAP HADIATION CONNECT CONOUCT THRU GAP WADIATION CONNECT CONDUET. THRU GAP RADIATION CONNECY CUNDUCT. PHAU GAP HADIATION CUNAECT CONDUCT. THAU GAP KADIATIOM CONAECT CONDUCT. THRU GAP RADIATION CONNECT CONDUCY THAU GA HADIATION CONMECP CONSTANT FIL CUEP RAOIATION CONNECI CONSTANT FILA COEF NADIATION CONNECT CONSTANT FILA COEF HADIATION CONNECT CONSTANT FILM COEF RADIATIUN CUNAECT CUNSIANT FILM COEF RADIATION CONNECT CONBTANT ILM COEF MADIATIUN CUNAECT CONSTANT FILM COEF GADIATION CONNECT WADIATION CONNECT
CONSTANT FILM COEF RADIATIUN CONNECT COMSTANT FILA COEF HADIATION CUNNECT CONSTANT FILA COEP RAOIATION CUNAECT CONBTANT FLM CUEF WAOIATION CONNECT CONSTANT FILM CUE HADIAYION CONAECY CONSTANT FILA COEF MAOTATION CONNECT CONBTANT FILA CUEF HADIATTION CUNAELT RADIATIIIN CUNAEC?

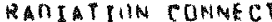

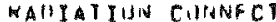
aubiarion cunnfet hamiartun cunaét Hall IATIUN CINAEECT - aljiat ION CONHAE *alliation rominect nabiarpun cunatet

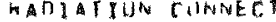
kallatige runefot Homiatring funtere Kailargun conacei 339.2800 524.2000 524,2000 412.0004 412.1004 904.760 904.9680 904.7680 904.7680 904.7680 904.7680 904.7680 904.7680 904.7000 904.7680 904.7680 904.7680 904.7680 904.7080 904.7680 904.9680 904.7680 Q01) 8680 344.9420 344.9420 40.6407 40.0407 2.0311 62.0310 37.6991 31.991

12.5664

12.5661

12.5664

12.5604

37.0998

37.699

62.631

- 28318

87. 9645

27.945

113.0972

113.097

65.9734

65.9754

150.7963

150.7903

20.4203

20.4203

131.2300

136.2300

150.7903

150.7963 446.9465

456.946

791.6007

791.6807

2201.9440

261.9448

423.3587

$4423.35 \%$

1960.3200

4574.0800

737.4400

1796.9000

3028.6944

2505.0560

5227.5200

उटट7. 5200

5227.5200

प्यद. "रeno

कर्रा. 5200

52.27 .5200

पeटा. 5200

5227.5200
$1715-05$ -49G9E 06 17 IE.05 . - 8135006 - 1360E-05 - $13 E$ E6 $1360 E-05$ \$8I 3506 $1300 E-05$ - A1 13506 $1360 E-05$ 831350 1130050 88I IE 06 - 1360 E 05 81 $13 \mathrm{t}=06$ $1300 t-05$ 8 $43 E=00$

- 35 OE 8813E06 13606005

- 4 I IEE 06

1360 - 05

- 13 I

- I3OE 05

.1940505

$1490 E 00$

1940605

1900 E 0 T

$1948 E$ OS

$1490 E$ : 07

104005

$140 E$ O 07

155 E.

- $929 \mathrm{E}$ O5

8 95E.05

$1929 E$. 05

$19555=0$

1920 DO 05

1955205

$1929 E-05$

19555.05

1 20 0 - 05

I TSEE.OS

1 Taqe. 0 .

1 1 55E 05

-1920E.05

$1955 E=05$

192 드은

$1401 \mathrm{E} 0 \mathrm{O}$

$1929 \mathrm{E}^{\circ} 0 \mathrm{~F}$

1704505

$1029 E 005$

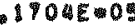

1929E0 05

$1704 E=05$

19295005

1 TOAE 0 OS

172 .

$1704 E=05$

$1929 E=05$

17OAE-05

$1704 \mathrm{E}-05$

$1704 \mathrm{~F}=05$

.17045005

$1704 E$ OS

- 17OAEDOS

$.1704 k 05$

$1104 t-05$

1704E 05

$1704 E-05$

- 170UE-05

$.1704 F=05$

$1704 \mathrm{k}=05$

irouk-05

$60435-05$

$16792=03$ . 93545 w03 . 5595 f50 .36395003

-561 पE OO - 7974E-OOS - $1230 \mathrm{~F}=02$ $.7974 E 03$ - I23OE-OZ . $774 \mathrm{aE} 6 \mathrm{C}$ - 1230500 1974 E 05 3230 E - 7974 E 03 - 1 E $30 E-02$ - 79 TEE 1230E-03 .7974 AE 03

- $1230 E-02$ $.7974 E-03$ $1230 E-0 E$ 1974503 1230002 3040E-0S - METEOOS T95E-00

$6033 E-06$

- I2Z4E

9350 00

T3A3E 00

$5315 E=06$

244 AE 00

1072 EO

2459 E 04

2 2424 E 0

- TzTE-Oa

TETEE OA

1 295005

121 EE 03

1720r-03

695003

- 231 IEO

21 BeEDOS

$1290 \mathrm{c} 0 \mathrm{O}$

$1273 E 0.03$

2945E 03

- 2909503

30938 04

3939E-OL

-2019E OJ

2660 E0 03

25705003

.2909E-0

- 829950

- 395 E 03

- $340 \mathrm{E}$ - 02

- JEYE 02

. 305se-02

- 4363EDOZ

$.7538 \mathrm{E}=02$

. $8533 E=02$ 
TAP-A INPUT (Cont'd)

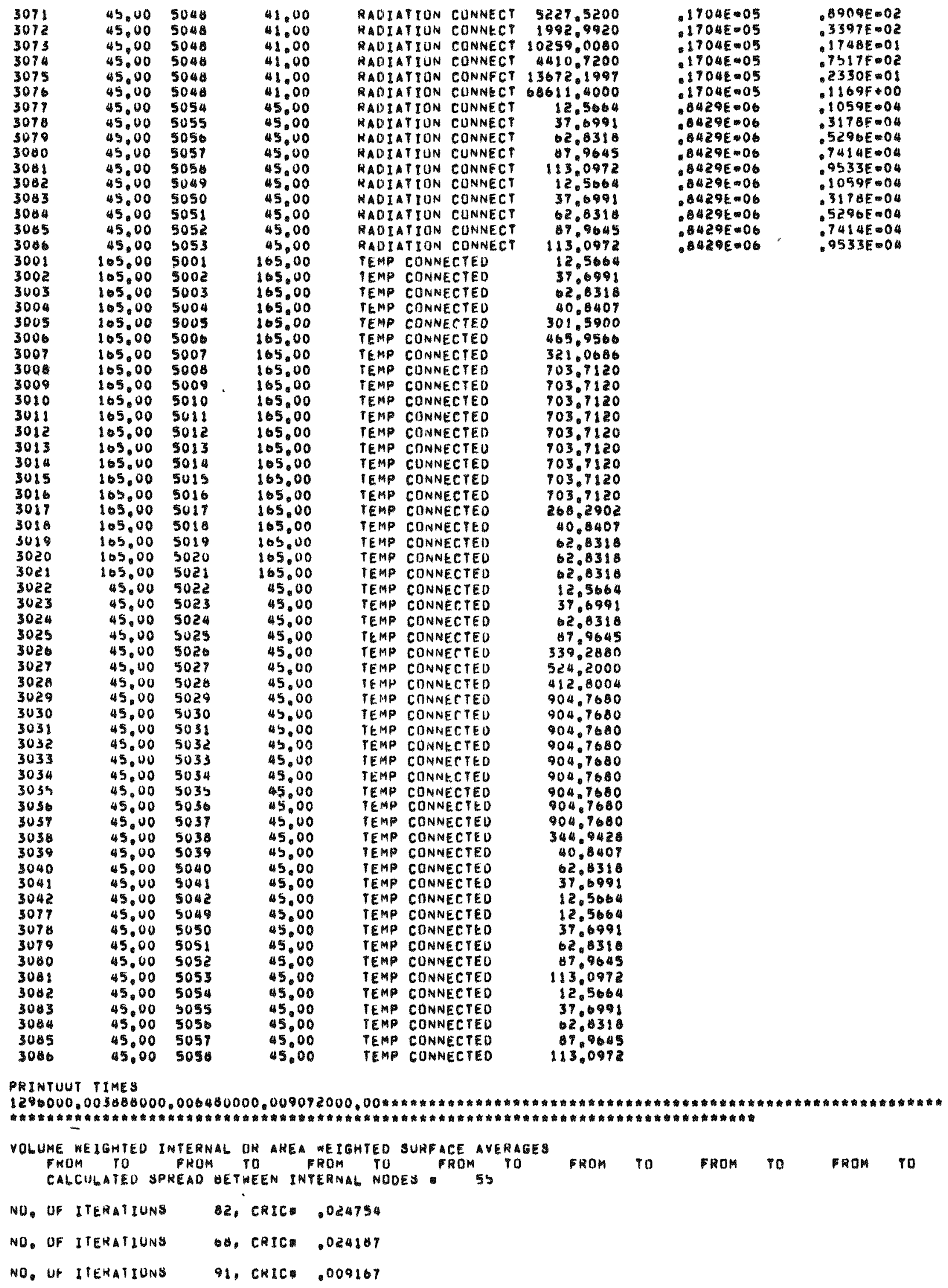




\begin{tabular}{|c|c|c|c|c|c|}
\hline NO. & of & TIEHATIUNS & 50 & CRIC & 1.000000 \\
\hline NL. & $\mathrm{UF}$ & ITERATIUNS & s. & $\mathrm{CH} 1 \mathrm{C}$ & 1.000000 \\
\hline NO. & UF & ITEA IIUHS & 96. & $C A D$ & $.00 N 540$ \\
\hline NO. & or & ITENAIIUNS & 60. & C IC & QOOANSS \\
\hline Nu. & $u$ & IIENATIUNS & 40. & CAIC & .005044 \\
\hline NO. & Wf & $I T E M A I I M S$ & 35. & $C N I C$ & .004450 \\
\hline ND. & wF & 【ENA】】UNS & 20, & $\mathrm{CHIC}$ & .1183150 \\
\hline NO & $n$ & $\| T_{A} \mid I U N D$ & $s_{0}$ & $r d t=$ & - 18 bouts \\
\hline NO. & (1) & IIEKAIIUKD & 15. & $r+1 \mathrm{C}$ & .027019 \\
\hline $\mathrm{NO}$ & 1) & 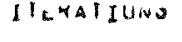 & 12. & ralc & - 124254 \\
\hline ND. & of & ITEHATIUN & 12 & CHIt & .030941 \\
\hline พิ4. & Uf & ITERATIUNS & 110 & $\cos \mathrm{co}$ & .05209 \\
\hline NO. & OF & ITERATIUN & 11. & CAIC & .054491 \\
\hline Ho. & OF & ITERATIUN & 10 & CRIC & .036372 \\
\hline NO. & $0 \%$ & IIERATIUNS & 10. & CAIC & .038302 \\
\hline NO. & of & ITERATIUNS & 10. & CUIC & .040350 \\
\hline NO. & $O P$ & TERATIUNS & 10. & CNIC & .03635 \\
\hline NO. & or & ITERATIUNS & 100 & CKI6 & .030025 \\
\hline No. & of & ITEHATUNS & 10. & CAIC: & .030030 \\
\hline $\mathrm{NO}_{\mathrm{B}}$ & op & ITEA TUNO & 10. & CAIE & .031319 \\
\hline No. & of & ITENAIUUN & 10 & CRIC & .025200 \\
\hline NO. & $0 \%$ & ITERAYIUNE & 10. & $\mathrm{CAC}$ & .027897 \\
\hline NO. & UF & IEAMIUNS & 160 & CAIC: & .019894 \\
\hline ND. & DF & ITERATIUNS & 110 & CNIC & .017293 \\
\hline ND. & OF & ITERAYIUNB & 120 & CA2C & .010583 \\
\hline$N U_{0}$ & UF & ITERATIUNE & 12 & CA1C: & 046060 \\
\hline NO, & $0 p$ & ITERATIUNO & 110 & CHIC & .017590 \\
\hline No. & uF & ITEHATIUNS & 110 & CAIC & .013935 \\
\hline No. & UF & ITEKATIUNS & 11. & $\cos 1 \mathrm{C}$ & .015407 \\
\hline NO. & ar & ITERAIUNO & $10_{0}$ & $\mathrm{CKIC}$ & 013142 \\
\hline NOP. & MF & ITEKATIUNS & 10, & $C \times 16=$ & $.016 n 70$ \\
\hline $\mathrm{NO}_{\mathrm{B}}$ & $n+$ & ITERAIIOIS & 10, & CKIC & .14053 \\
\hline NU. & $\mathrm{itr}$ & ITEHAIIUNS & 111, & CAICa & .013409 \\
\hline NU. & $\| F$ & HtWAIUNS & 10. & CKIC & -115UAH \\
\hline NU. & UF & LTEKATIUNS & lu, & CNIC & .0131105 \\
\hline
\end{tabular}




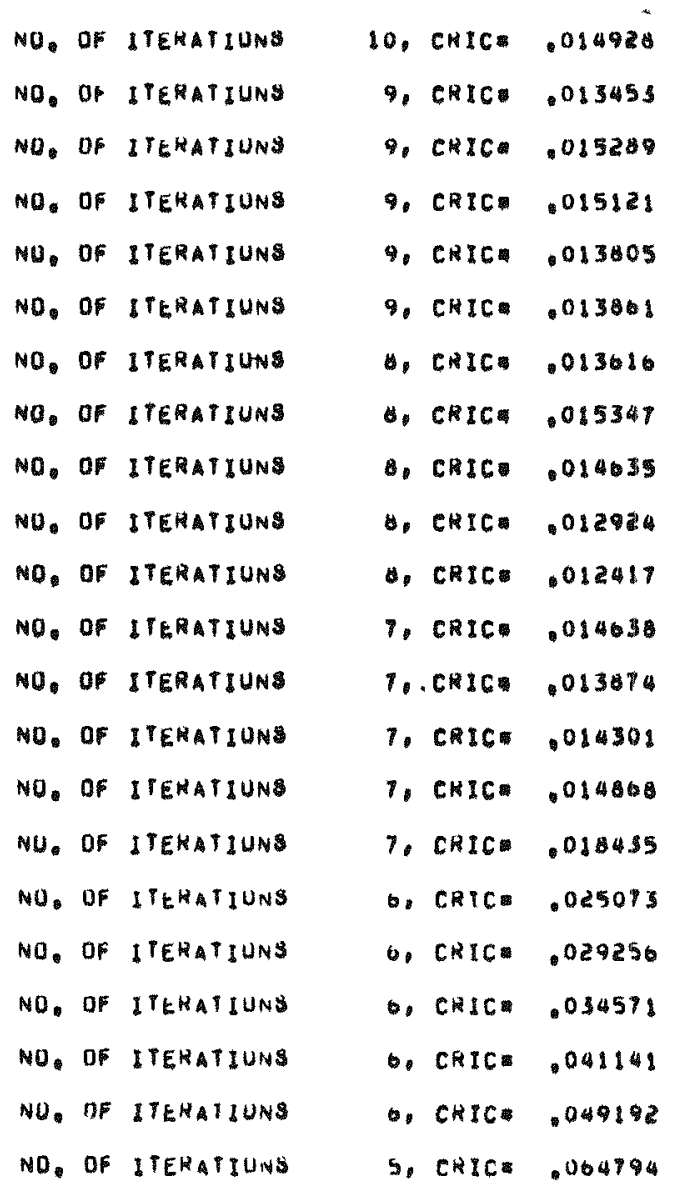


TAP-A OUTPUT

TEMPERATURE CALCULATION FOR 946 HOURS

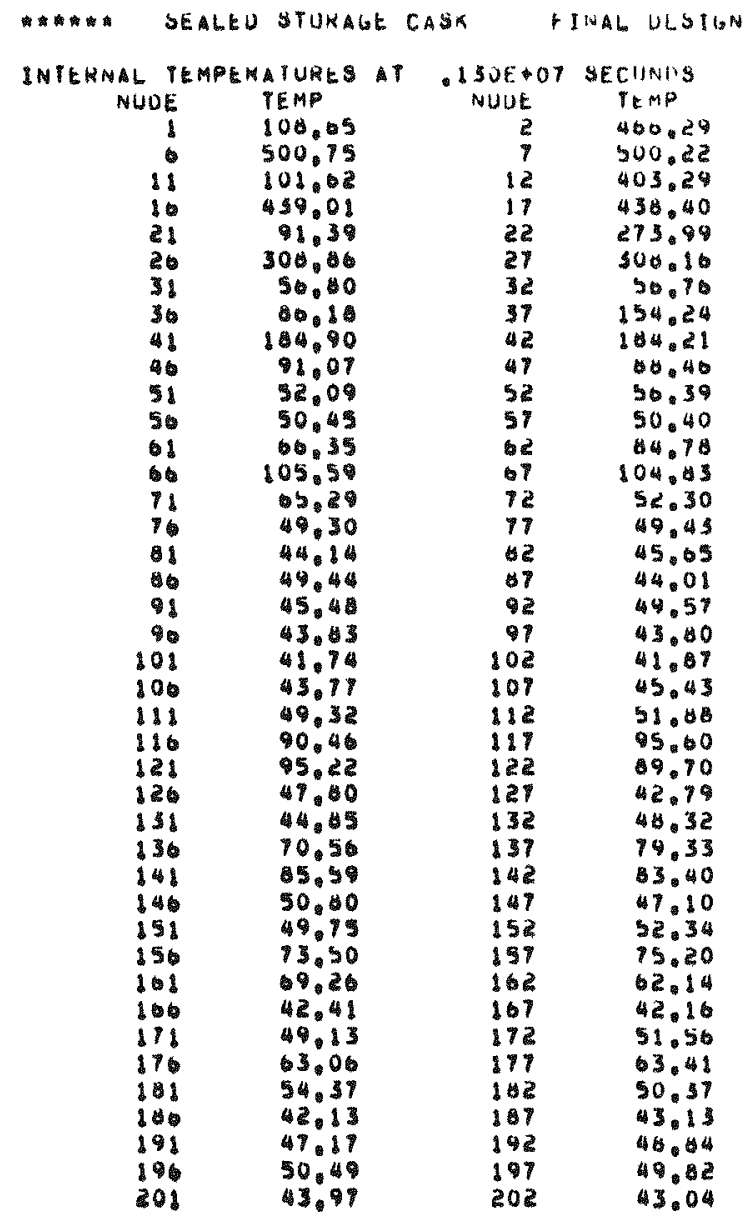

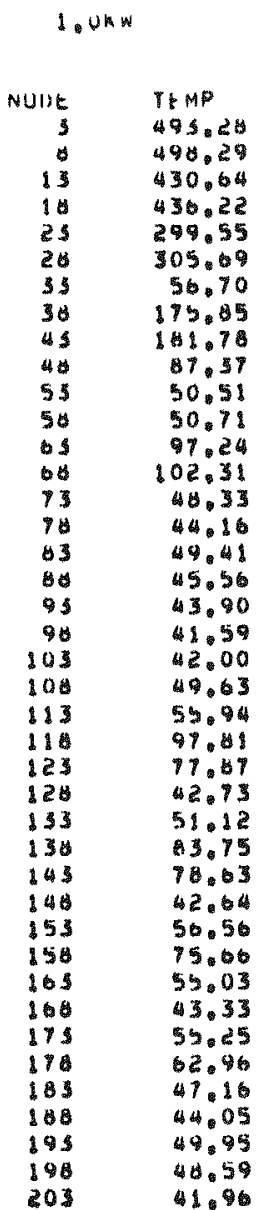

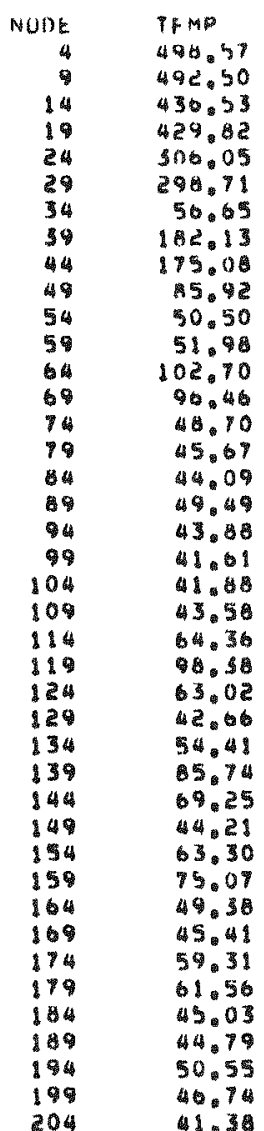

IF

500.53

4365

396.14

30 . 1

269.77

56.45

104,36

152,42

8. 13

50.4

60.39

105.00

3.

49.03

49.9

45.1

45.8

4 .

41.0

42.45

45.29

19.30

97.5

59.91

43.0

60.4

80.26

58.86

47.07

6. 1

7. 1

40.20

47.42

6. 1.8

5.63

41.36

45.75

5. I

450 
TAP-A OUTPUT

TEMPERATURE CALCULATIONS FOR 1665 HOURS

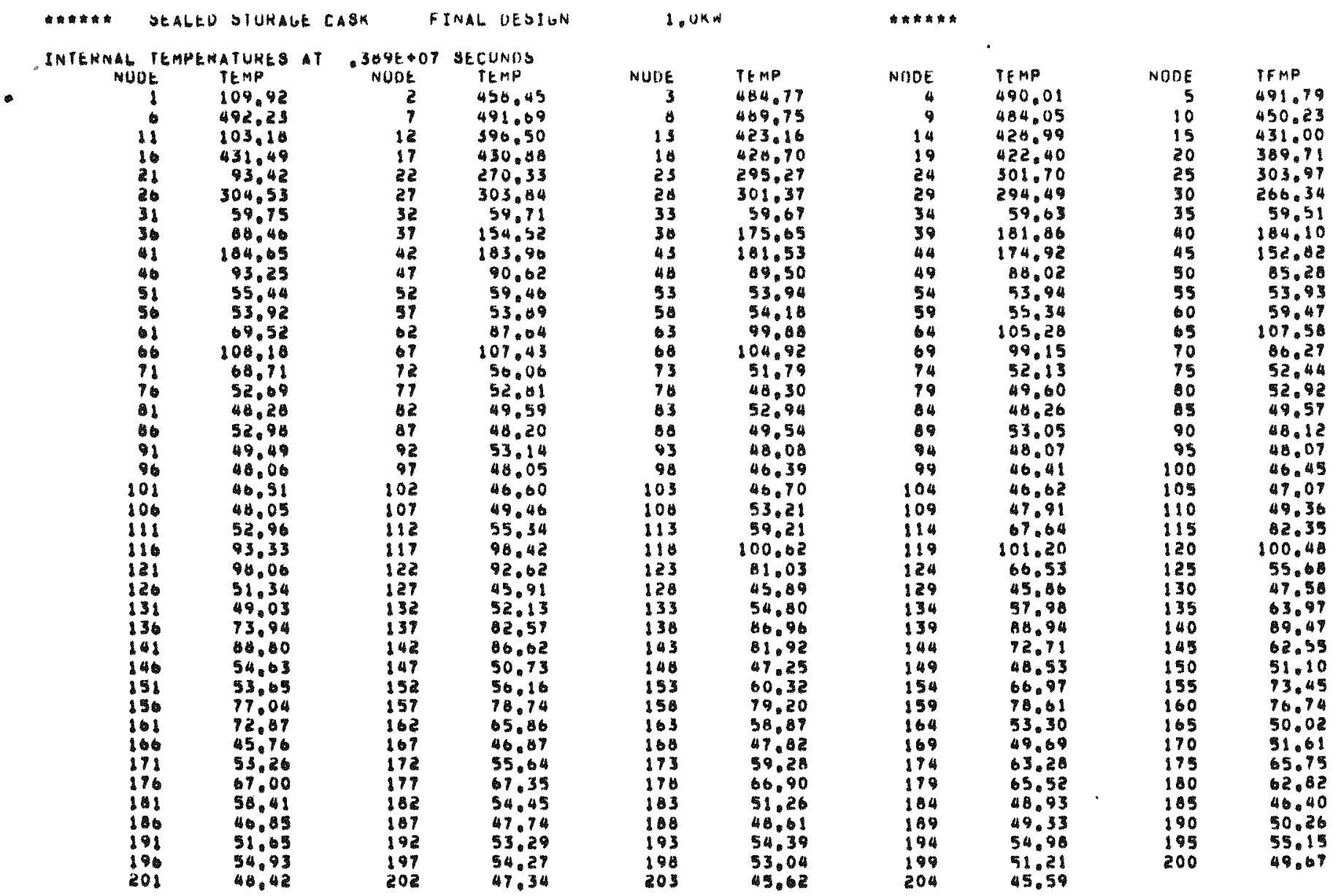


TAP-A OUTPUT (Continued)

TEMPERATURE CALCULATIONS FOR 2388 HOURS

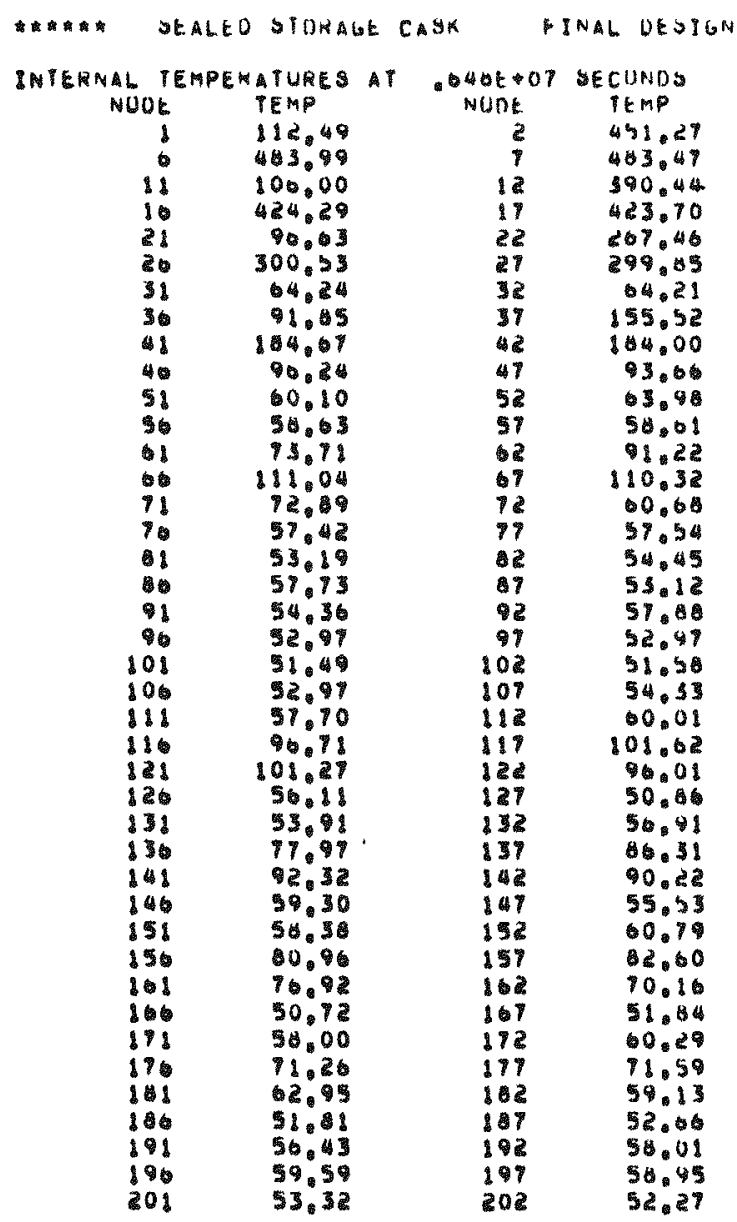

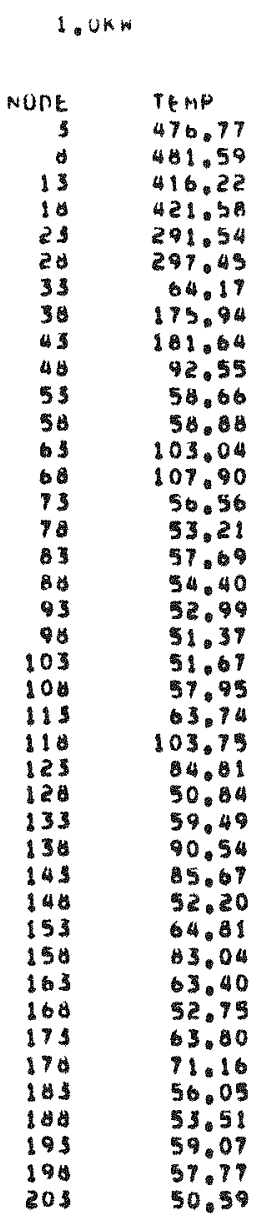

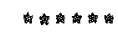

\begin{tabular}{|c|c|c|c|}
\hline NUDE & IEM & NODE & If \\
\hline 4 & 431.65 & 5 & 40.57 \\
\hline 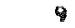 & 476.06 & 10 & 443.34 \\
\hline 14 & 421.00 & 15 & 423.1 \\
\hline 19 & 415,47 & 20 & 383.60 \\
\hline 24 & 297.78 & 25 & 2989 \\
\hline 29 & 290.77 & 30 & Ė3.5 \\
\hline 34 & $\$ 43$ & 35 & 5.03 \\
\hline 39 & 11196 & 10 & 184.15 \\
\hline 4 & 175.25 & 5 & 153.8 \\
\hline 40 & 1.00 & 50 & 80.40 \\
\hline 54 & 54.60 & 55 & 56.05 \\
\hline 39 & 60,00 & 0 & 69.99 \\
\hline 64 & 108,25 & 65 & 110.47 \\
\hline 69 & 102.32 & 70 & 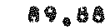 \\
\hline 74 & 50.6 & 75 & 57.80 \\
\hline 99 & 54.6 & 80 & 57.67 \\
\hline 84 & 33.17 & 65 & 5.43 \\
\hline 69 & 57.79 & 80 & $55_{6} 04$ \\
\hline 94 & 52.99 & 85 & 52. \\
\hline 99 & 92.9 & 100 & 51.4 \\
\hline 104 & 51.54 & 105 & 52.03 \\
\hline 109 & $52-4$ & 110 & 54.23 \\
\hline 114 & 11.8 & 115 & 11 \\
\hline 118 & 104,31 & 120 & 103.00 \\
\hline 124 & 70.99 & 125 & 00.31 \\
\hline 129 & 50.31 & 130 & 5.51 \\
\hline 154 & .2 .5 & 135 & 60.35 \\
\hline 130 & 92.5 & 140 & 92.96 \\
\hline 144 & 70.78 & $\$ 45$ & 60.95 \\
\hline 149 & 53.43 & 150 & 8.1 \\
\hline 154 & 11.24 & 155 & 7.50 \\
\hline 159 & 82.7 & 160 & 0.60 \\
\hline 104 & 58.01 & 165 & 34.64 \\
\hline 169 & 54.55 & 170 & 59.40 \\
\hline 174 & 67.7 & 175 & 70.05 \\
\hline 179 & 0.02 & 180 & 0.21 \\
\hline 108 & 53.0 & 185 & 51.38 \\
\hline 80 & 54.9 & 190 & 55.20 \\
\hline 194 & 59.4 & 195 & 59.13 \\
\hline 199 & 56.00 & 200 & 5.52 \\
\hline
\end{tabular}


TAP-A OUTPUT (Continued)

TEMPERATURE CALCULATIONS FOR 3104 HOURS

\begin{tabular}{|c|c|c|c|c|c|c|c|c|c|}
\hline 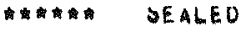 & STURAGE & $3 k$ & $N A L$ DESTGN & & & ค* & & & \\
\hline 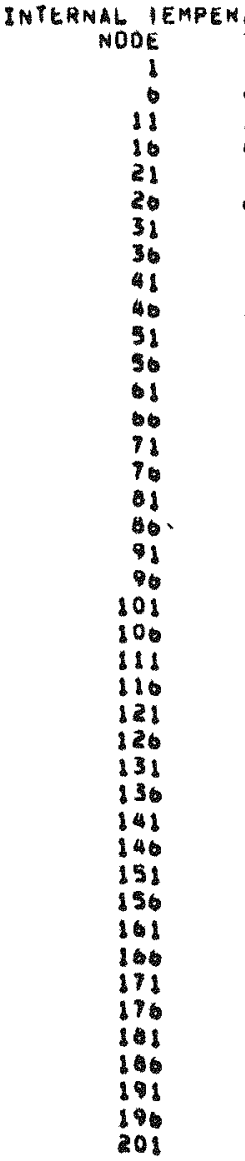 & 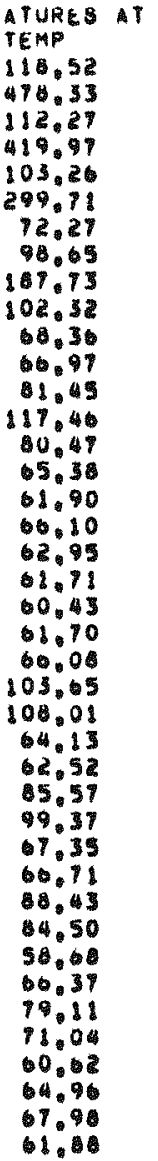 & 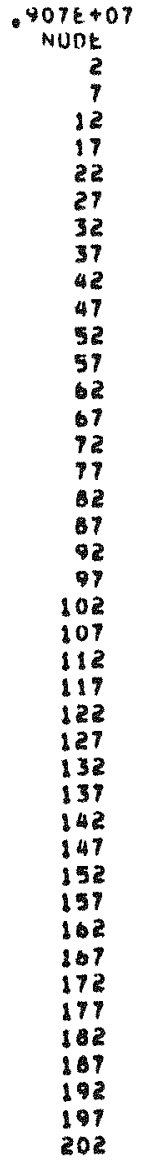 & 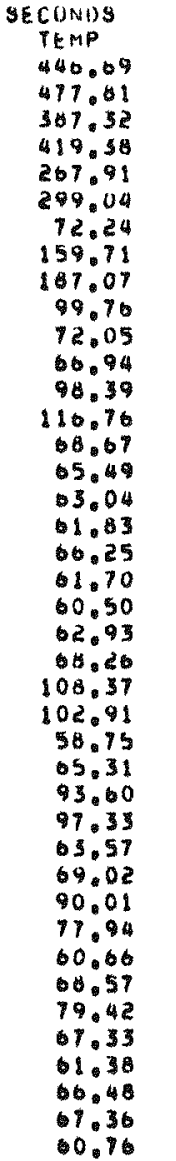 & $\begin{array}{r}\text { NunE } \\
5 \\
13 \\
18 \\
23 \\
28 \\
33 \\
38 \\
43 \\
48 \\
53 \\
58 \\
03 \\
68 \\
13 \\
18 \\
13 \\
48 \\
93 \\
94 \\
103 \\
108 \\
115 \\
118 \\
123 \\
128 \\
133 \\
138 \\
143 \\
148 \\
153 \\
158 \\
163 \\
168 \\
175 \\
178 \\
183 \\
188 \\
193 \\
198 \\
203\end{array}$ & $\begin{array}{l}74 m \\
471.35 \\
475.94 \\
412.17 \\
417.32 \\
291.05 \\
290.70 \\
72.20 \\
179.31 \\
184.77 \\
98.60 \\
67.00 \\
67.20 \\
109.77 \\
114.41 \\
64.55 \\
61.91 \\
66.06 \\
02.99 \\
61.72 \\
60.33 \\
60.59 \\
66.31 \\
71.63 \\
110.41 \\
92.06 \\
58.73 \\
67.76 \\
97.07 \\
92.93 \\
60.99 \\
72.69 \\
90.43 \\
71.36 \\
61.44 \\
11.94 \\
79.00 \\
64.31 \\
62.18 \\
67.49 \\
66.22 \\
58.74\end{array}$ & $\begin{array}{r}\text { NoOt } \\
4 \\
9 \\
14 \\
19 \\
24 \\
29 \\
34 \\
39 \\
44 \\
49 \\
54 \\
59 \\
64 \\
69 \\
74 \\
79 \\
64 \\
89 \\
94 \\
99 \\
104 \\
109 \\
114 \\
119 \\
124 \\
129 \\
134 \\
139 \\
144 \\
149 \\
154 \\
159 \\
164 \\
169 \\
114 \\
179 \\
184 \\
189 \\
194 \\
199 \\
204\end{array}$ & 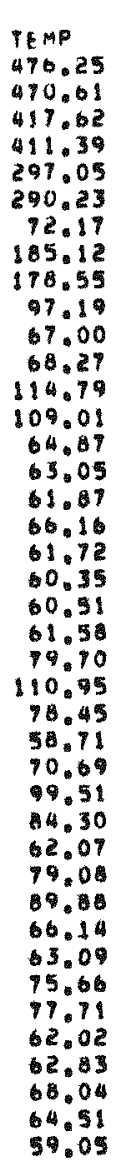 & $\begin{array}{r}\text { NDOE } \\
5 \\
10 \\
15 \\
20 \\
25 \\
30 \\
35 \\
10 \\
45 \\
50 \\
55 \\
80 \\
15 \\
10 \\
75 \\
10 \\
15 \\
90 \\
95 \\
100 \\
105 \\
110 \\
115 \\
120 \\
125 \\
130 \\
135 \\
140 \\
145 \\
150 \\
155 \\
100 \\
165 \\
170 \\
175 \\
160 \\
185 \\
190 \\
195 \\
200\end{array}$ & 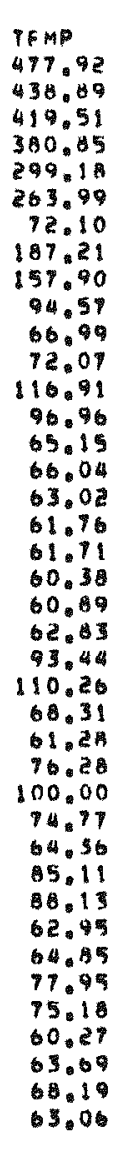 \\
\hline
\end{tabular}


TAP-A OUTPUT (Continued)

TEMPERATURE CALCULATIONS FOR 3835 HOURS

\begin{tabular}{|c|c|c|c|}
\hline \$EALEO & D STUKAGE & 8 & INAL DESIGN \\
\hline 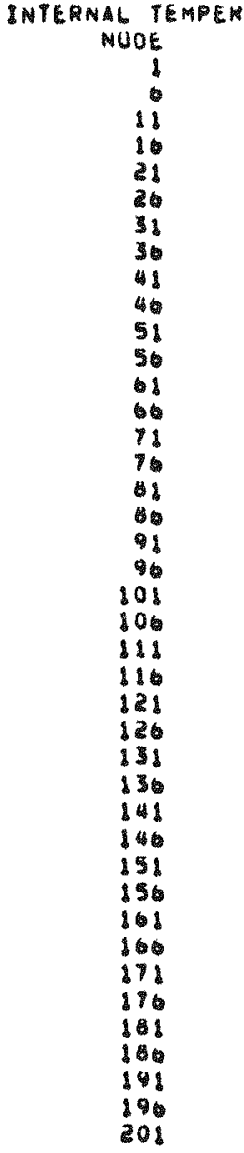 & 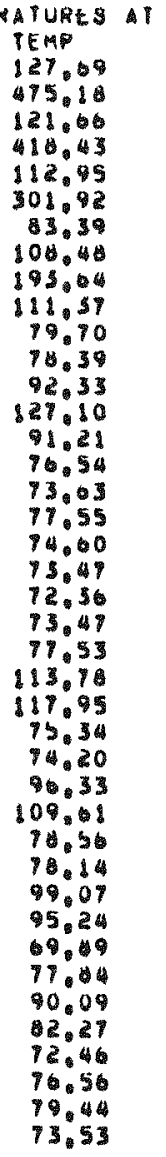 & $\begin{array}{c}117+00 \\
\text { Nobt } \\
7 \\
7 \\
12 \\
17 \\
22 \\
27 \\
32 \\
37 \\
42 \\
47 \\
32 \\
57 \\
12 \\
67 \\
72 \\
17 \\
12 \\
17 \\
92 \\
47 \\
102 \\
107 \\
112 \\
117 \\
122 \\
127 \\
132 \\
157 \\
142 \\
147 \\
152 \\
157 \\
162 \\
167 \\
112 \\
117 \\
182 \\
187 \\
192 \\
197 \\
202\end{array}$ & 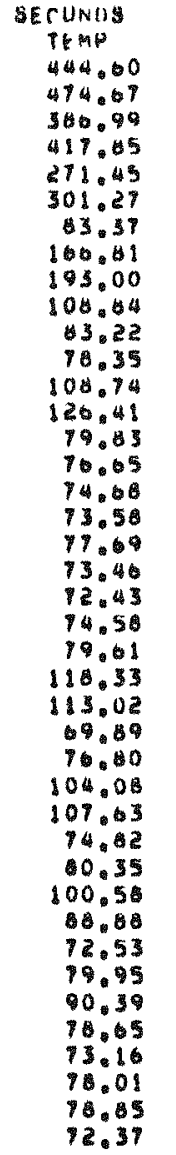 \\
\hline
\end{tabular}

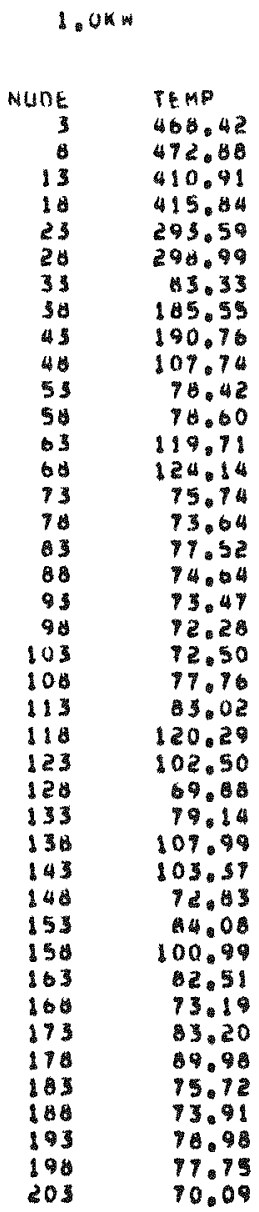

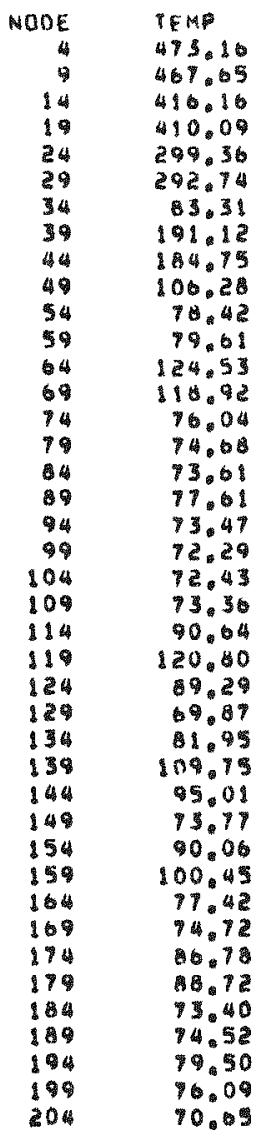

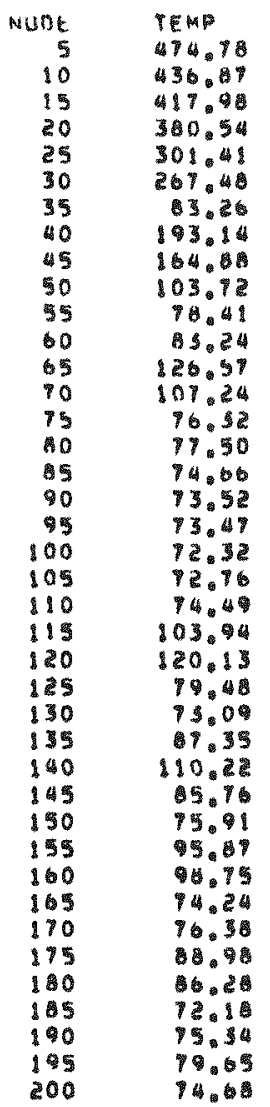


TAP-A OUTPUT (Continued)

TEMPERATURE CALCULATIONS FOR 4557 HOURS

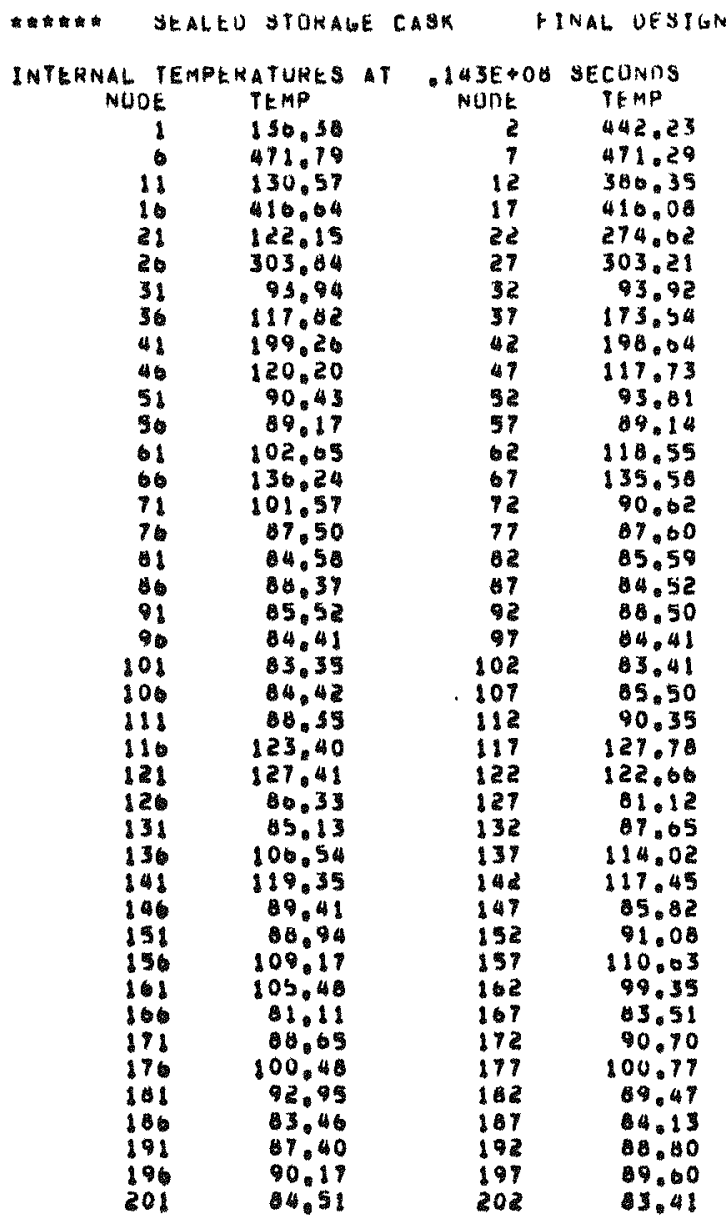

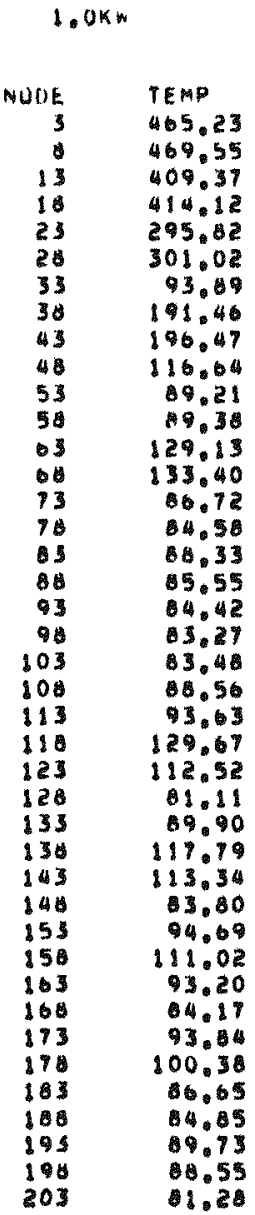

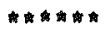

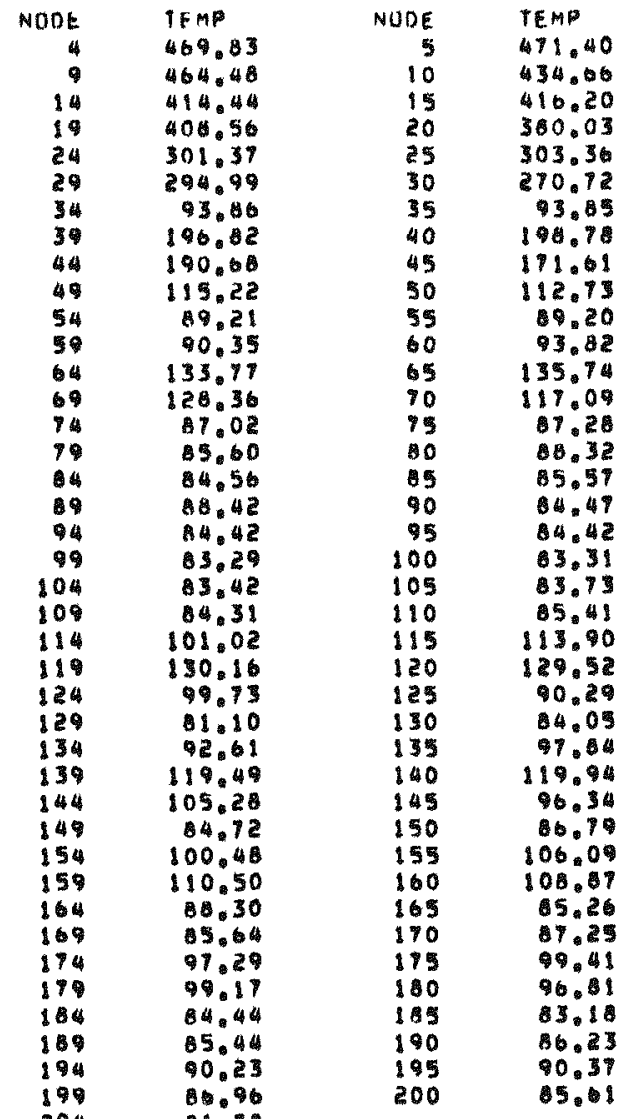


TAP-A OUTPUT (Continued)

TEMPERATURE CALCULATIONS FOR 5252 HOURS

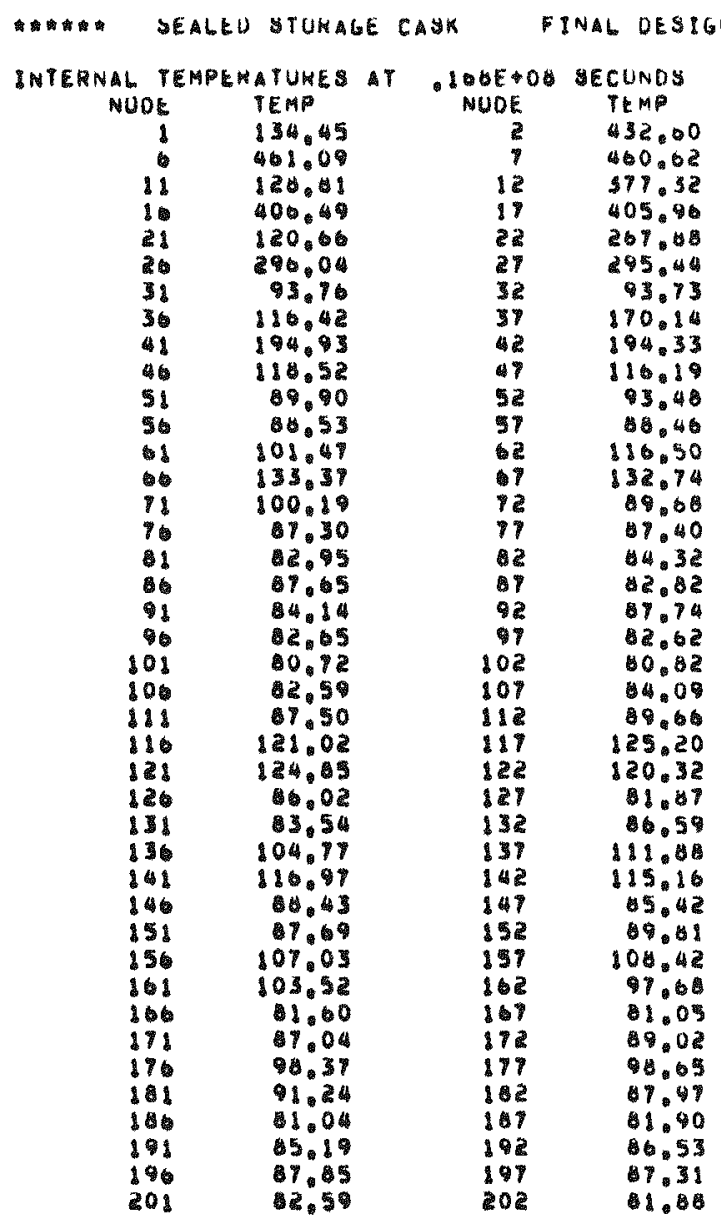

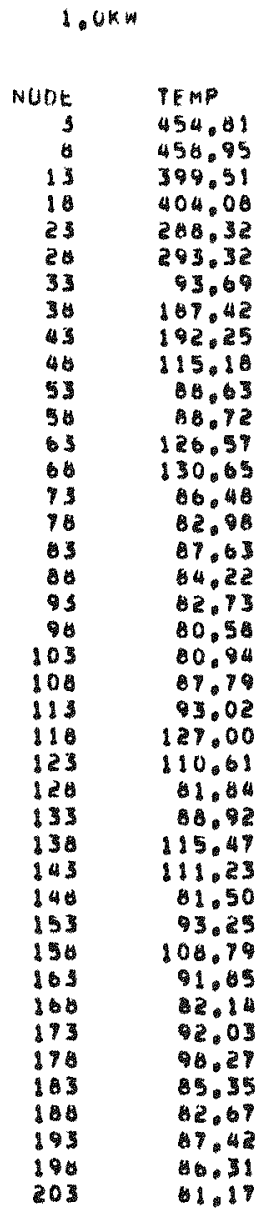

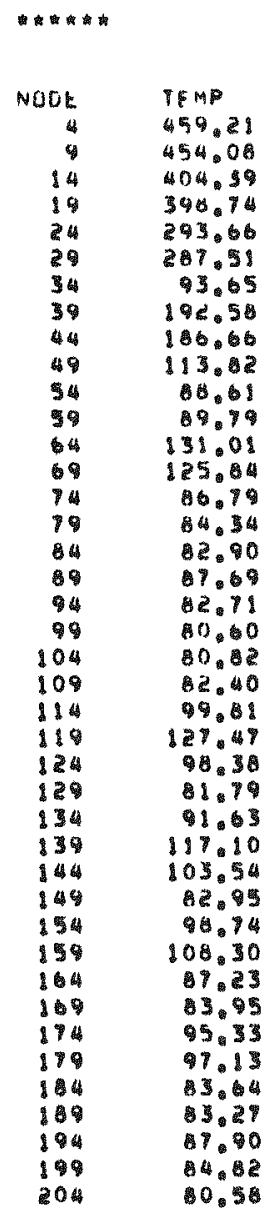

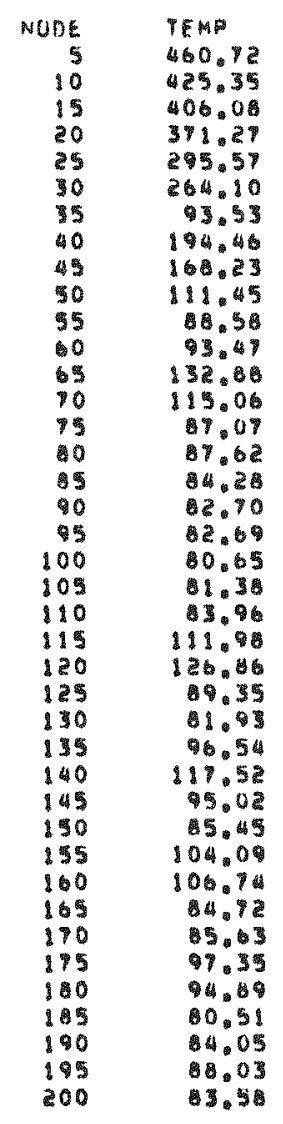


TAP-A OUTPUT (Continued)

TEMPERATURE CALCULATIONS FOR 5974 HOURS

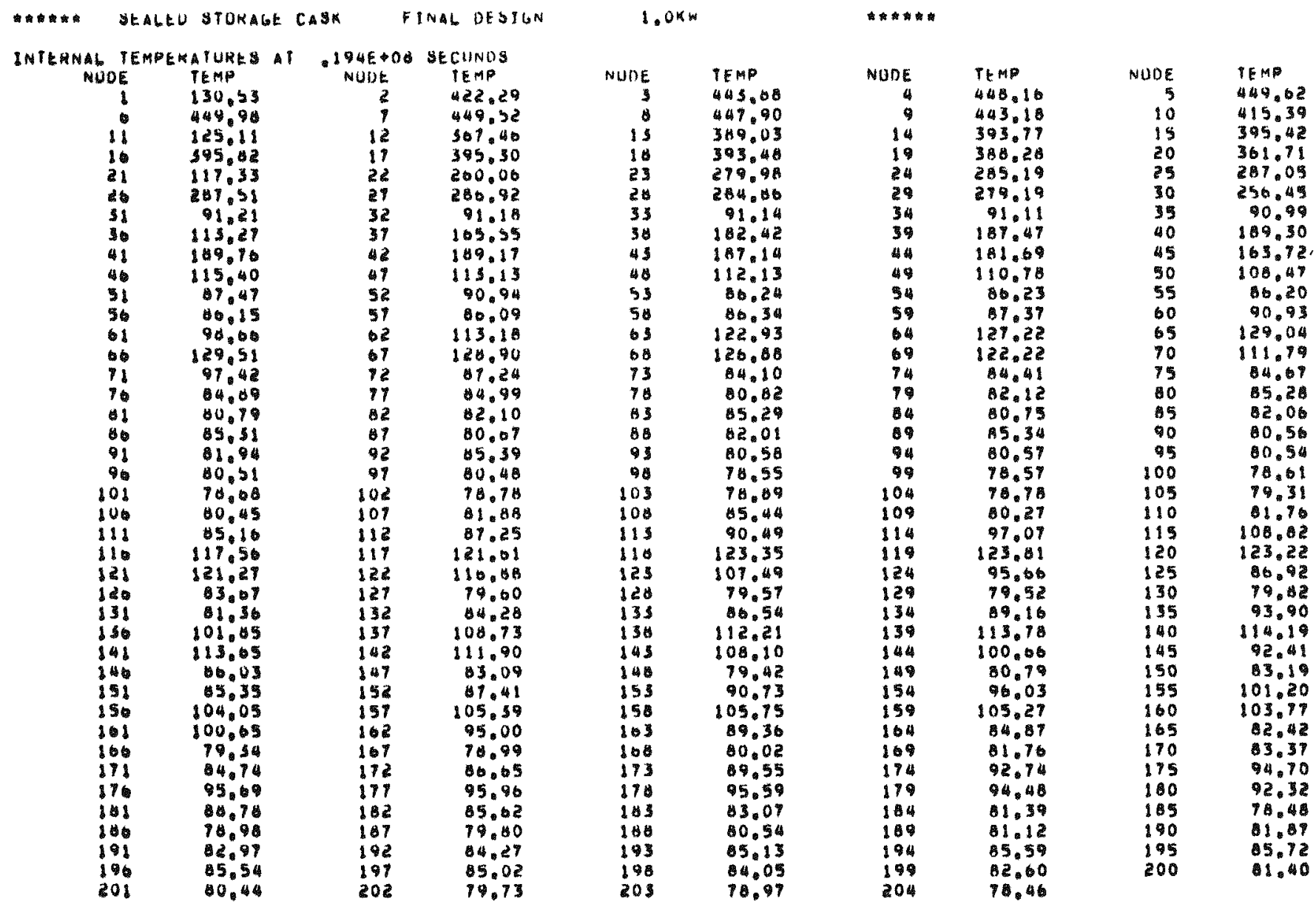


TAP-A OUTPUT (Continued)

TEMPERATURE CALCULATIONS FOR 6696 HOURS

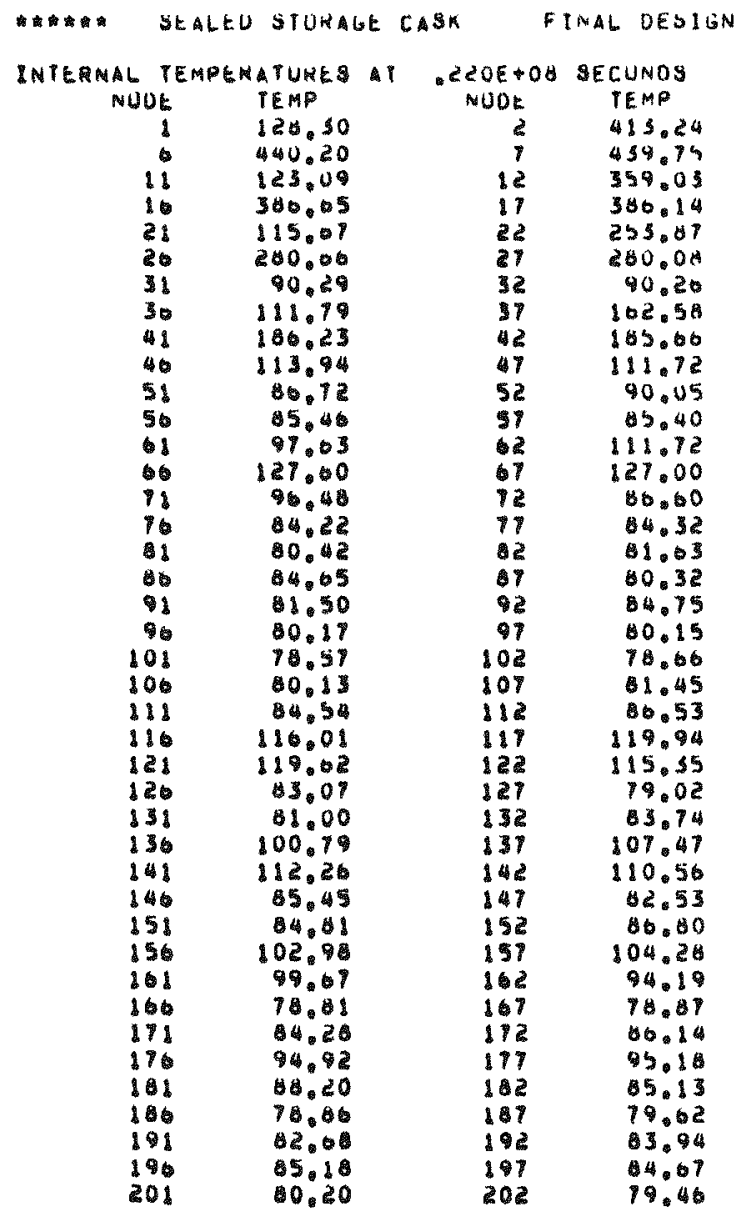

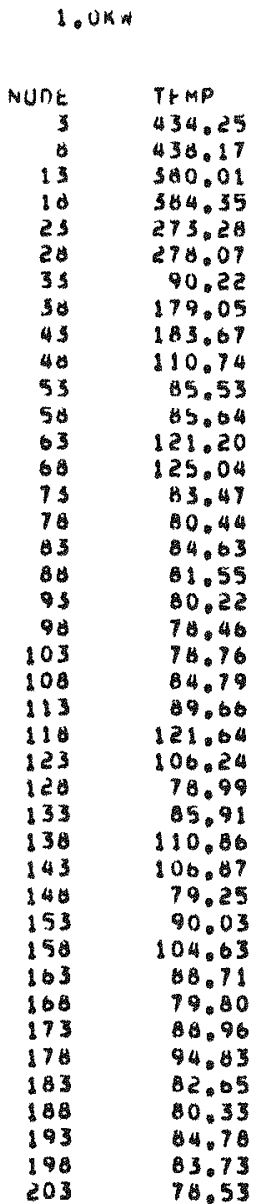

\begin{tabular}{|c|c|}
\hline NDDE: & $\begin{array}{l}T E M P \\
464.4 E\end{array}$ \\
\hline 4 & 435.50 \\
\hline 14 & $3 A A_{0}$ \\
\hline 19 & 379.29 \\
\hline 24 & 270.39 \\
\hline 29 & 272.53 \\
\hline 34 & 90.19 \\
\hline 39 & 183.90 \\
\hline 44 & 170.54 \\
\hline 40 & 109.30 \\
\hline 34 & 85.52 \\
\hline 50 & 60.03 \\
\hline 64 & 125.37 \\
\hline 89 & 220.51 \\
\hline 94 & 83.76 \\
\hline 79 & 1.64 \\
\hline 04 & 80.38 \\
\hline 89 & 40.69 \\
\hline 99 & 70.47 \\
\hline 104 & 78.08 \\
\hline 100 & 79.90 \\
\hline 18 & 90.09 \\
\hline 199 & 122,09 \\
\hline 124 & 94.78 \\
\hline 129 & 78.9 \\
\hline 134 & 86.40 \\
\hline 139 & 112.59 \\
\hline 144 & 99.64 \\
\hline 149 & 60.49 \\
\hline 154 & 95.19 \\
\hline 159 & 104.17 \\
\hline 164 & 84,35 \\
\hline 169 & B1.42 \\
\hline 174 & 92.06 \\
\hline 179 & 93.75 \\
\hline 184 & 00.96 \\
\hline 189 & 80.89 \\
\hline 194 & 5.23 \\
\hline $\begin{array}{l}199 \\
204\end{array}$ & 82.32 \\
\hline
\end{tabular}

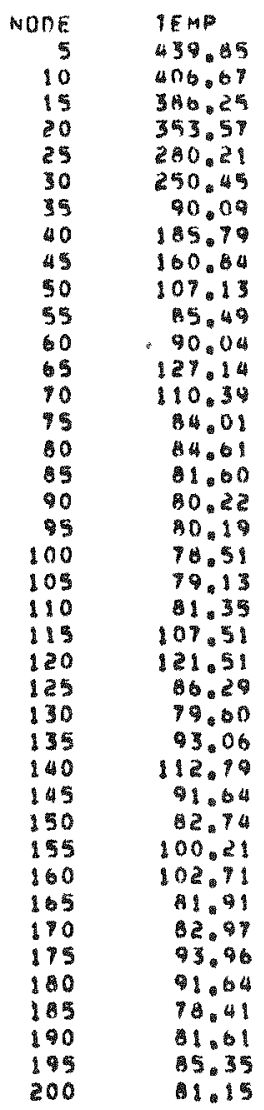


TAP-A OUTPUT(Continued)

TEMPERATURE CALCULATIONS FOR 7418 HOURS

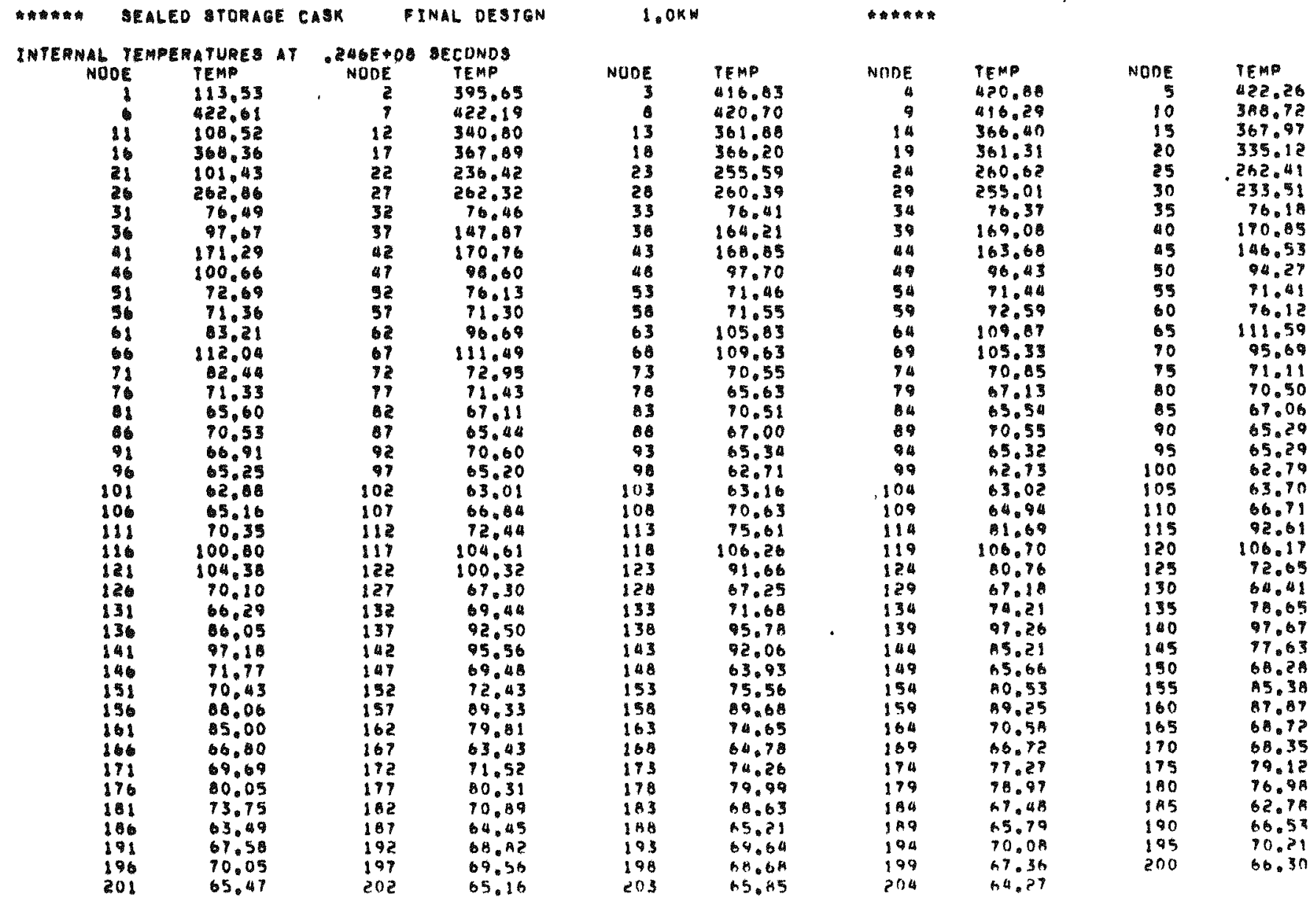


TAP-A OUTPUT (Continued)

TEMPERATURE CALCULATIONS FOR 8140 HOURS

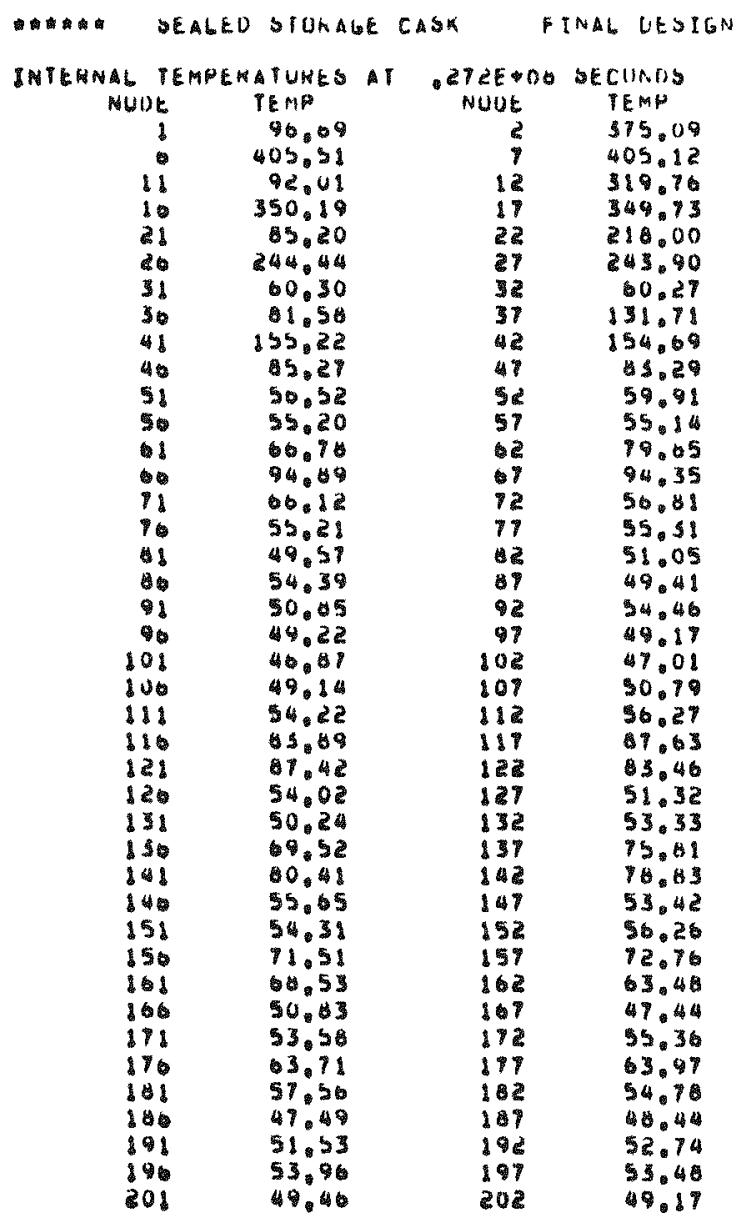

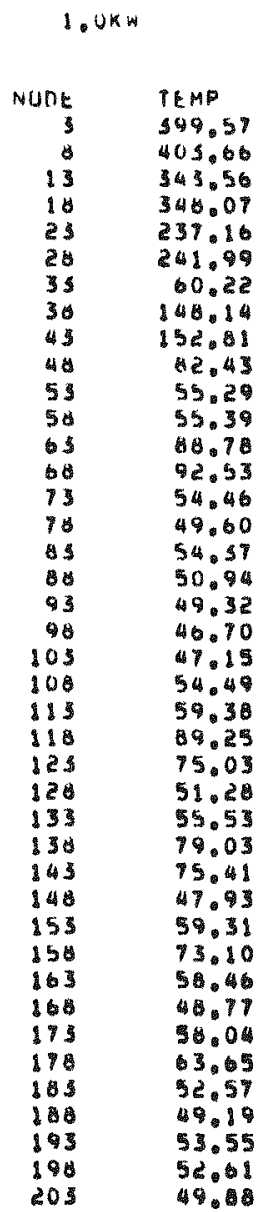

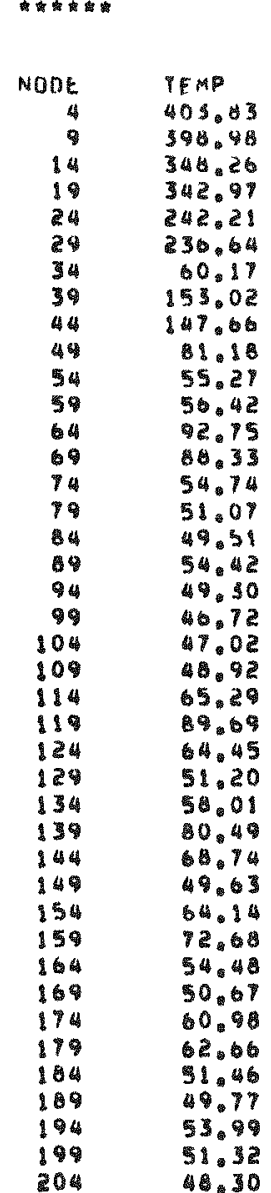

\begin{tabular}{|c|c|}
\hline $\begin{array}{r}\text { NinE } \\
5 \\
10 \\
15 \\
20 \\
25 \\
90 \\
35 \\
40 \\
45 \\
50 \\
55 \\
60 \\
15 \\
10 \\
75 \\
80 \\
15 \\
90 \\
95 \\
100 \\
105 \\
110 \\
115 \\
120 \\
125 \\
130 \\
135 \\
110 \\
145 \\
150 \\
155 \\
160 \\
165 \\
170 \\
175 \\
160 \\
165 \\
190 \\
195 \\
200\end{array}$ & 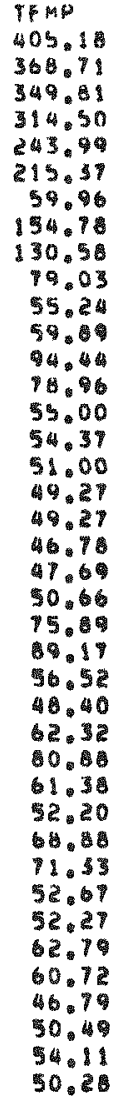 \\
\hline
\end{tabular}


TAP-A OUTPUT (Continued)

TEMPERATURE CALCULATIONS FOR 8862 HOURS

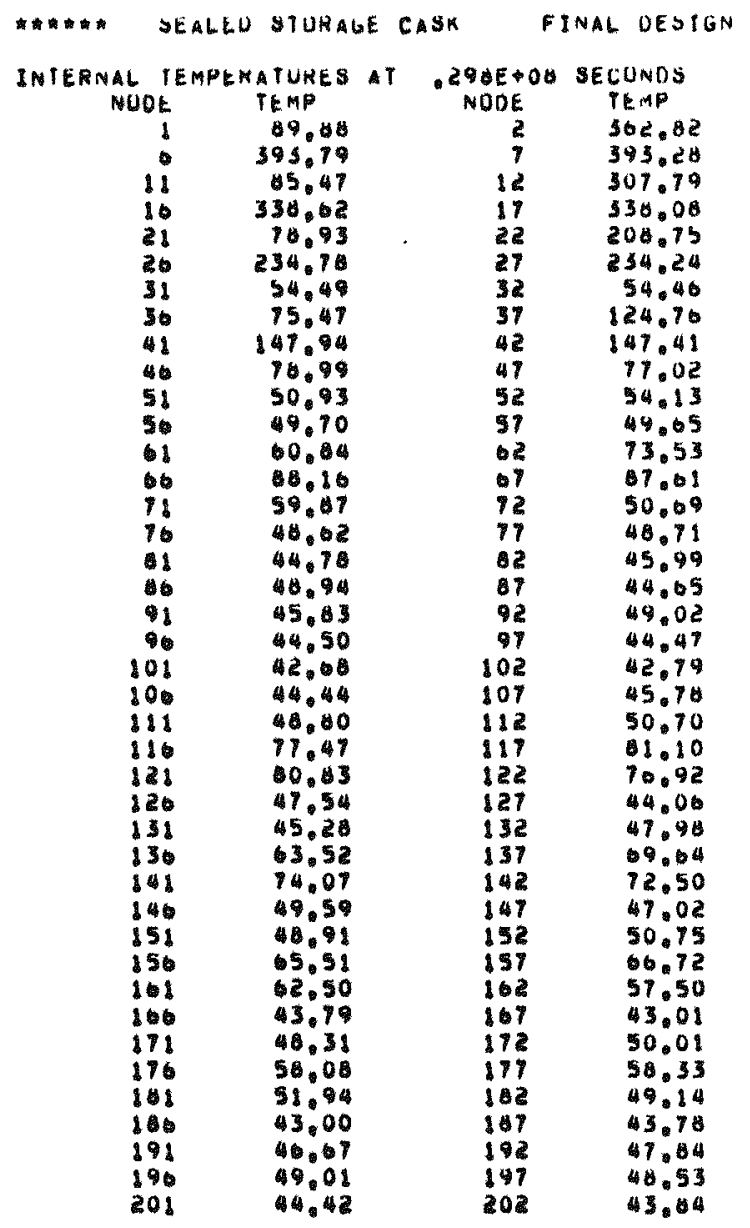

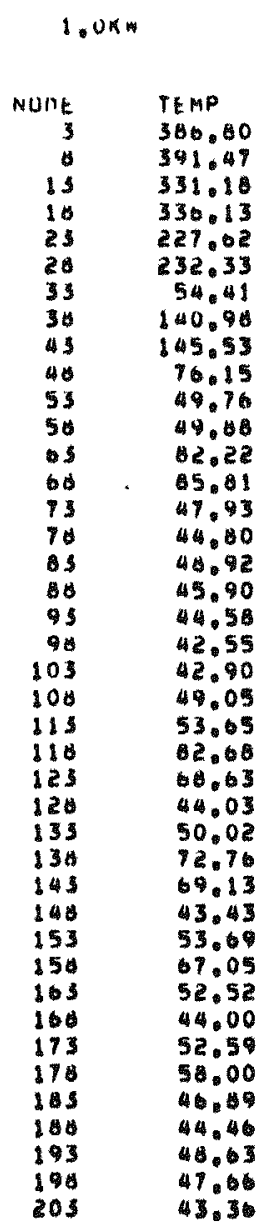

71
NOOH
4
9
14
19
24
29
34
59
44
49
54
59
64
69
74
79
84
89
94
99
104
109
114
119
124
129
134
139
144
149
154
159
164
169
174
179
184
189
194
199
204

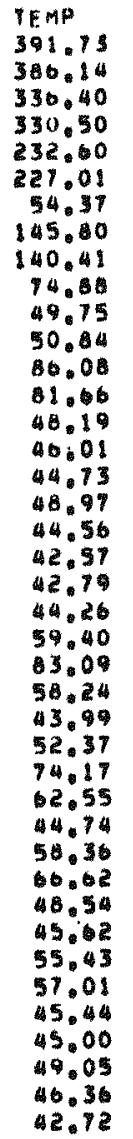

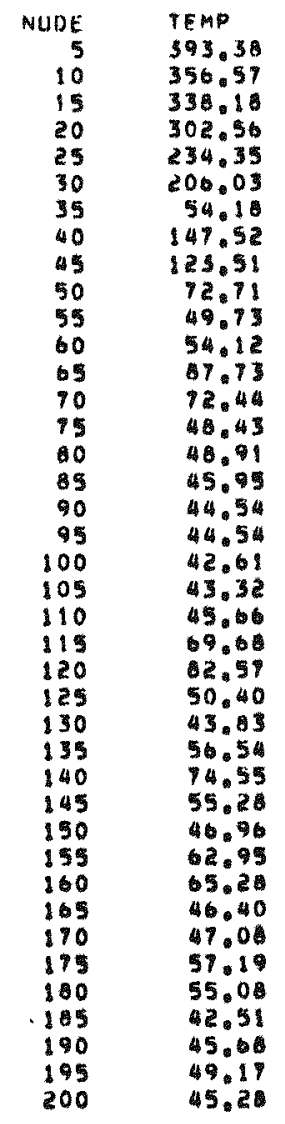


TAP-A OUTPUT (Continued)

TEMPERATURE CALCULATIONS FOR 9585 HOURS

\begin{tabular}{|c|c|c|c|c|c|c|c|}
\hline 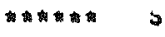 & $S \in A L E D$ & SUNALE & $E c$ & $8 x$ & NAL DESIGN & & \\
\hline $\begin{array}{l}\text { INTERNAL T } \\
\text { NUDE }\end{array}$ & $T E A P E$ & $\begin{array}{l}\text { ATURE } \\
\text { TEMP }\end{array}$ & A. T & $\begin{array}{l}\text { S2AE } \\
\text { NUDE }\end{array}$ & $\begin{array}{c}\text { SECUNDS } \\
\text { TEMP }\end{array}$ & NUDE & TEMP \\
\hline 1 & 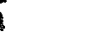 & 45,36 & & 2 & $\$ 52.01$ & 3 & 37504 \\
\hline 0 & 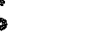 & 502.25 & & 7 & 501.75 & 6 & 379.96 \\
\hline d) & & 01.10 & & 8 & 297.51 & 13 & 320.3 \\
\hline 10 & & 327.09 & & 7 & 327.10 & 10 & 52325 \\
\hline 21 & & 70.8 & & 22 & 201.32 & 23 & 219.13 \\
\hline 2 & & 220.05 & & 27 & 220.35 & 20 & 224.0 \\
\hline 31 & & 50.80 & & 32 & 50.95 & 33 & 50.90 \\
\hline 36 & & 71.25 & & $\$ 7$ & 119.77 & 30 & 135.70 \\
\hline 41 & & 142.54 & & 42 & 14201 & 43 & 140.17 \\
\hline 40 & & 75.15 & & 47 & 73.23 & (4) & 72.38 \\
\hline 1 & & 47.3 & & 52 & 50.5 & 53 & 46.40 \\
\hline 5 & & 40.54 & & 7 & 46.30 & 54 & 4.52 \\
\hline 1 & & 57.10 & & 2 & .50 & 13 & 17.95 \\
\hline 0 & & 83.15 & & 67 & 85.20 & 6 & 61.44 \\
\hline 71 & & 50.45 & & 12 & 47.30 & 73 & 44,5 \\
\hline 76 & & a & & 77 & 45.32 & 7 & 41.04 \\
\hline 18 & & $41 \cdot 2$ & & 82 & 42.77 & 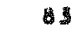 & 45.5 \\
\hline 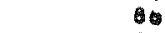 & & 45.61 & & 8 & 41.50 & 60 & \& \\
\hline 1 & & 42.0 & & 92 & 45.6 & 93 & 41.45 \\
\hline 10 & & 41.56 & & 97 & 41.3 & 96 & 39.51 \\
\hline 101 & & 39.4 & & 102 & 34,14 & 105 & 39.85 \\
\hline 100 & & 41,30 & & $10 \%$ & 42.57 & 100 & 45.72 \\
\hline it 1 & & 45.40 & & 112 & 47.32 & 115 & 30.13 \\
\hline is & & 73.33 & & 117 & 7.01 & 110 & 78.1 \\
\hline 12 & & 701 & & 122 & 12,0 & 123 & 64.74 \\
\hline 126 & & 44.19 & & 127 & 40.75 & 121 & 40.72 \\
\hline 131 & & 42,10 & & 132 & 44.9 & 133 & 40.67 \\
\hline 836 & & 59.7 & & 15 & 5.13 & 134 & 0.79 \\
\hline 141 & & 70.05 & & 142 & 00.53 & 143 & 65.24 \\
\hline 140 & & $40 \div 24$ & & 147 & 43,0 & 140 & 40.35 \\
\hline ds & & 45.61 & & 132 & 47.5 & 151 & 50.25 \\
\hline 15 & & 61.14 & & 157 & 62.92 & 156 & 03.24 \\
\hline 18 & & 50.01 & & 162 & 53.95 & 105 & 49.09 \\
\hline 100 & & 40.50 & & 167 & 34.9 & 160 & 40.3 \\
\hline 171 & & 45.04 & & 172 & 40.70 & 173 & 4.20 \\
\hline 170 & & $54: 34$ & & 177 & 54.78 & 178 & 54.47 \\
\hline 181 & & 48.50 & & 12 & 45.05 & 183 & 43.63 \\
\hline 106 & & 59.94 & & 101 & 40.00 & 100 & 41.34 \\
\hline 191 & & 4349 & & 192 & 4.03 & 193 & 45.39 \\
\hline 196 & & 45.77 & & 197 & 45.30 & 190 & 44.45 \\
\hline 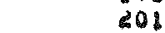 & & 42,29 & & 202 & 40.9 & 203 & 40.12 \\
\hline
\end{tabular}

19
NoDE
4
9
14
19
24
29
34
39
44
49
54
39
64
69
14
79
64
69
94
99
104
199
114
119
124
129
134
199
144
149
154
159
164
189
194
179
184
199
194
199
204

TEMP

380.23

325.52

$310^{173}$

224.72

दा 19.24

50.86

140.43

135.15

11.14

46.39

4.44

1.11

77.40

44.82

42.79

4.

45.64

41.41

39.53

59.75

$4 ! .13$

55.7

98.81

40.63

40.95

70.15

50.54

41.5

54.79

62.02

45.22

42.44

51.99

53.50

4 ह. 19

41.8

45.21

13. 1.18

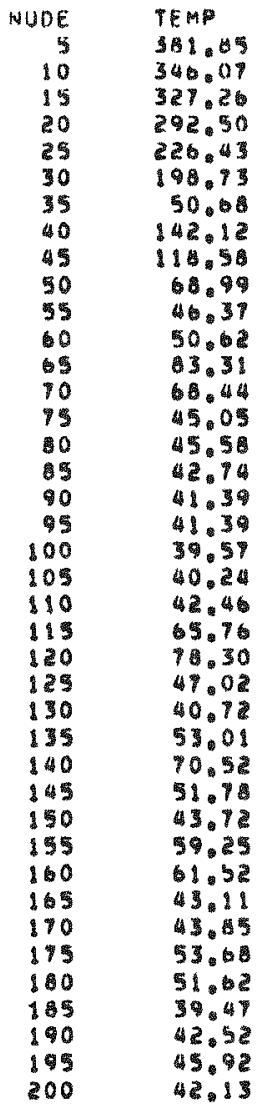


TAP-A OUTPUT (Continued)

TEMPERATURE CALCULATIONS FOR 10307 HOURS

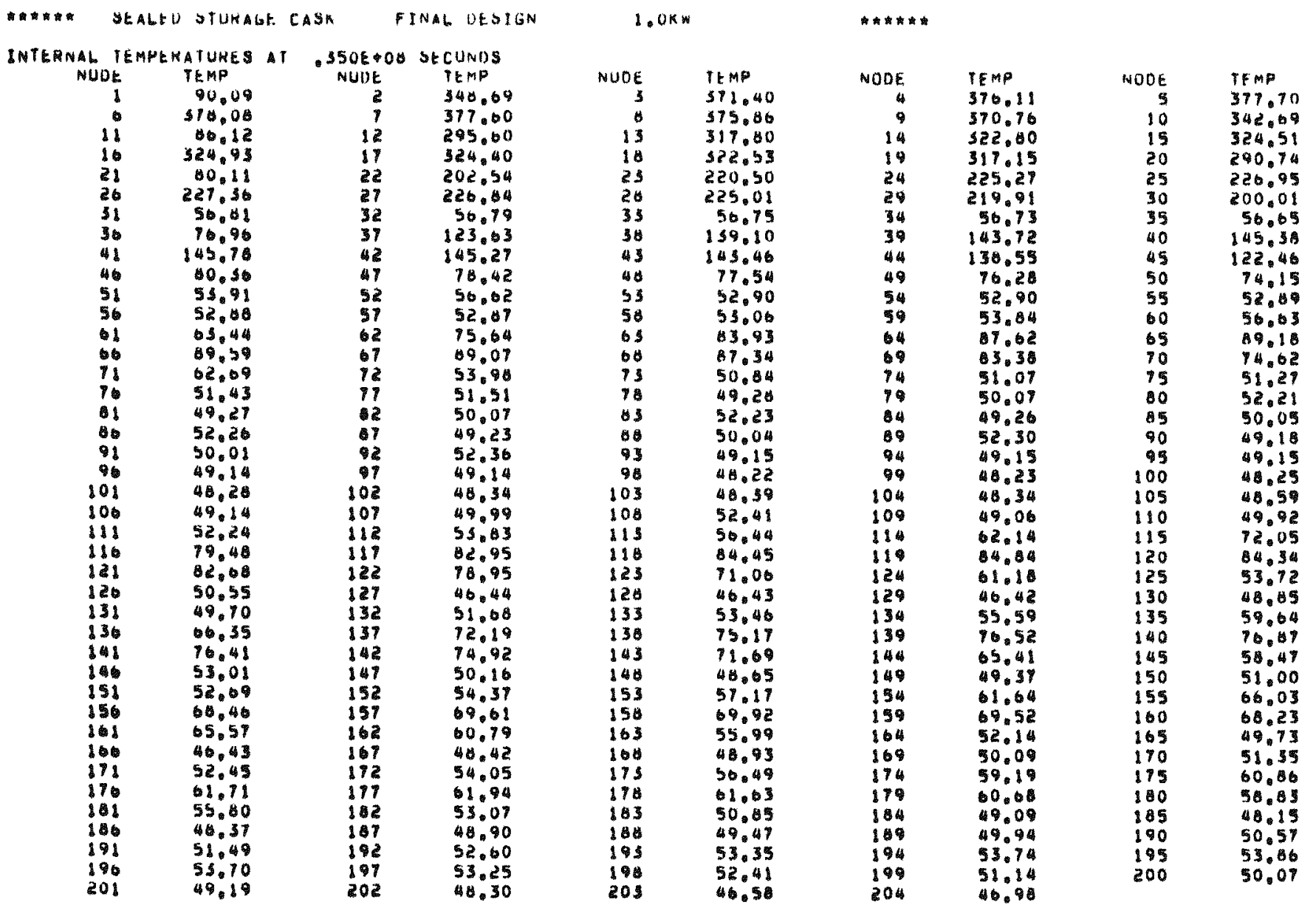




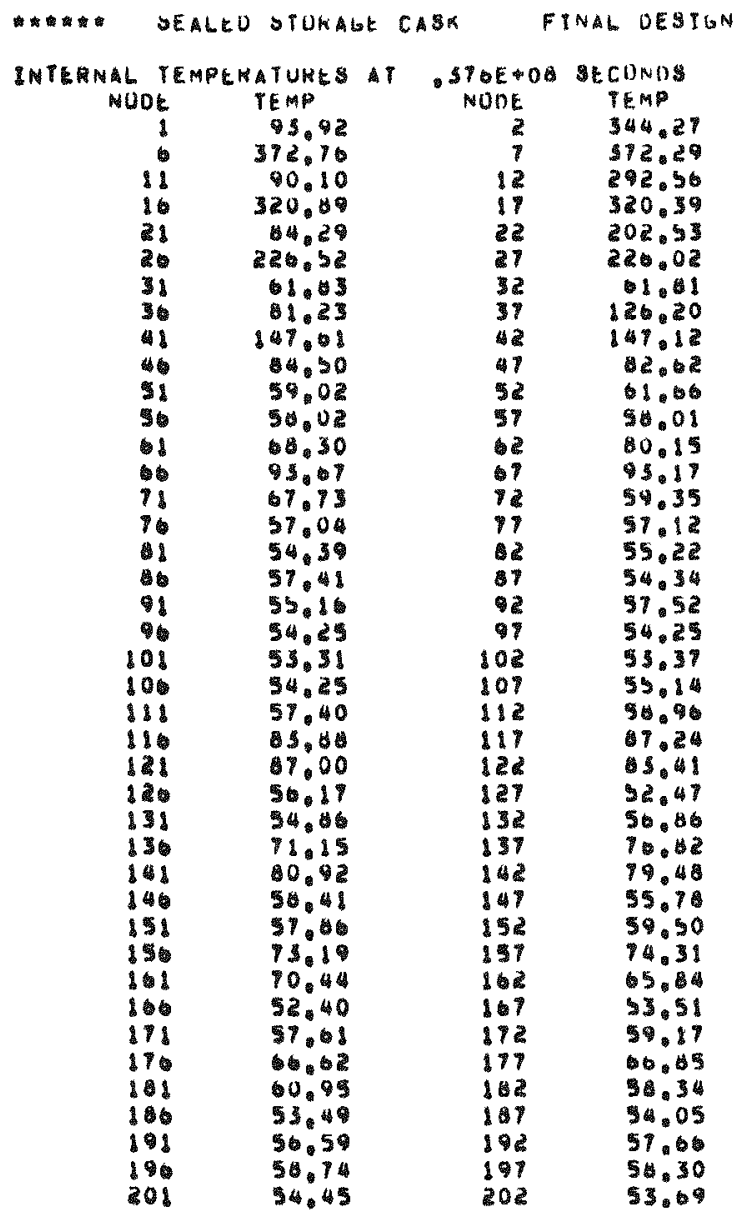

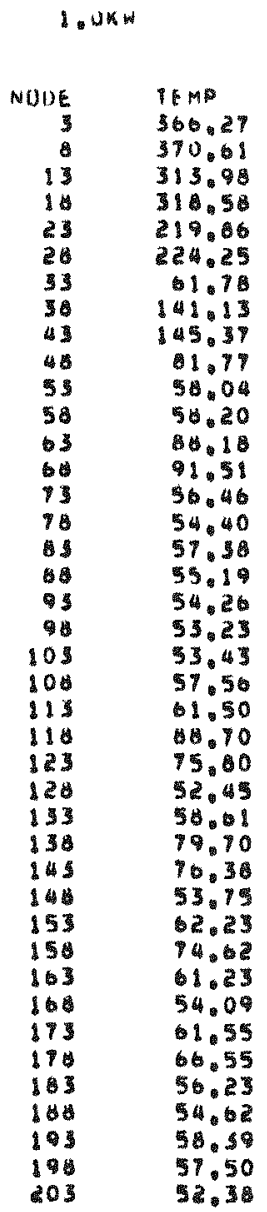

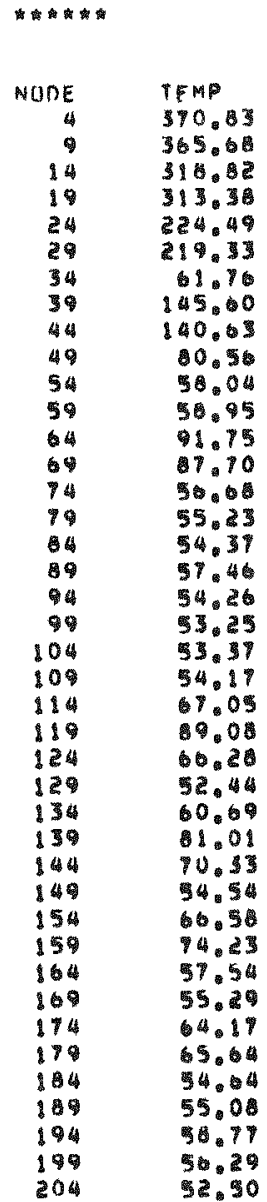

\begin{tabular}{|c|c|}
\hline $\begin{array}{r}\text { NODE } \\
5 \\
10 \\
15 \\
20 \\
25 \\
10 \\
35 \\
40 \\
45 \\
50 \\
55 \\
60 \\
65 \\
10 \\
75 \\
100 \\
65 \\
90 \\
15 \\
100 \\
105 \\
110 \\
115 \\
120 \\
125 \\
130 \\
115 \\
140 \\
145 \\
190 \\
155 \\
160 \\
165 \\
170 \\
175 \\
180 \\
125 \\
190 \\
195 \\
200\end{array}$ & 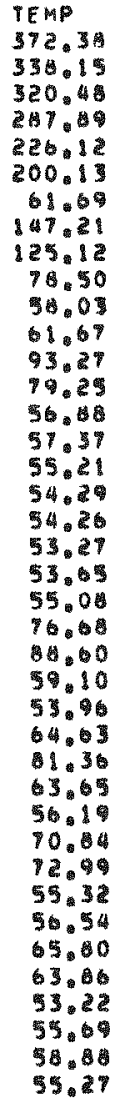 \\
\hline
\end{tabular}


TAP-A OUTPUT (Continued)

TEMPERATURE CALCULATIONS FOR 11752 HOURS

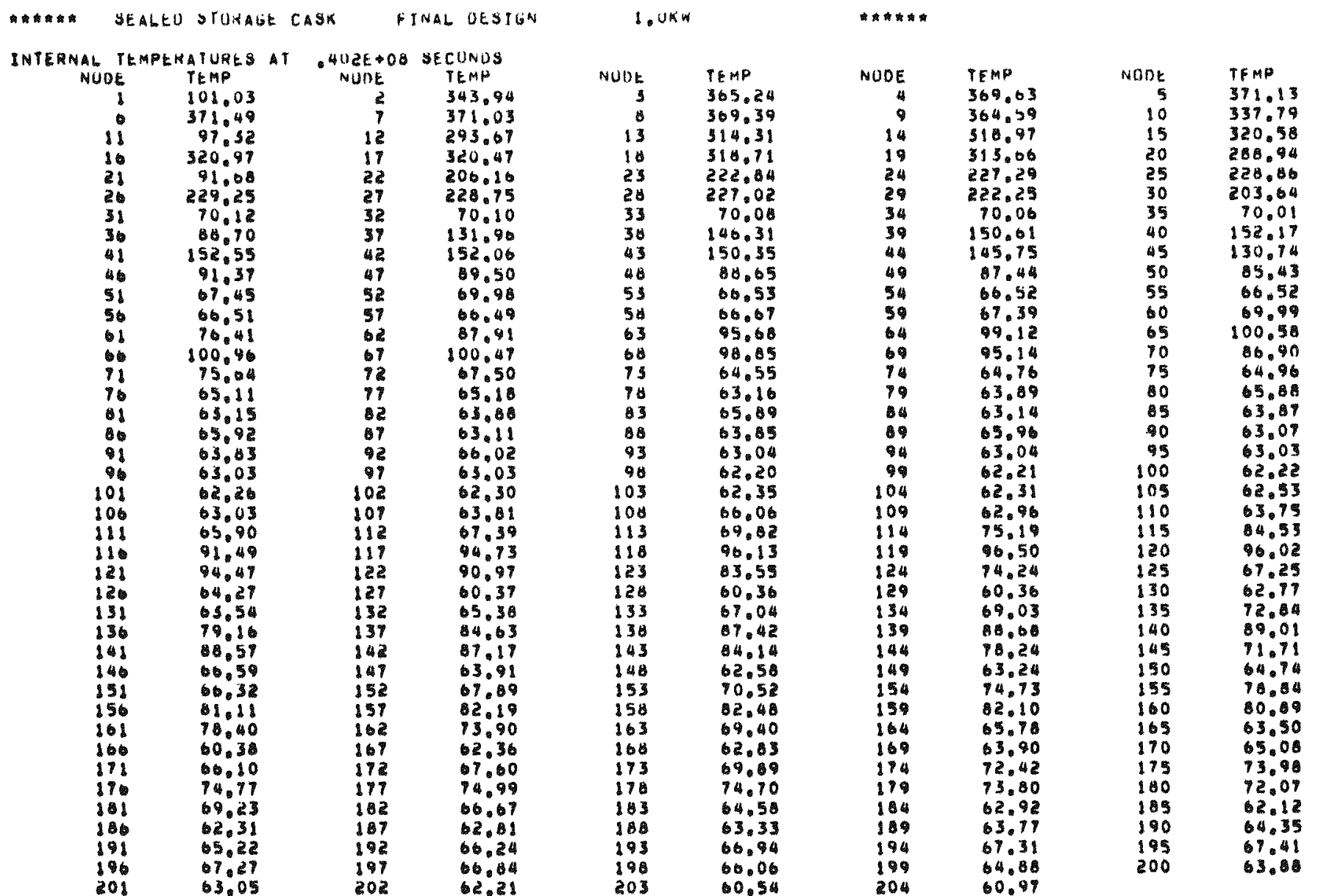




\section{APPENDIX C \\ THERMAL CONDUCTIVITY OF CONCRETE EVALUATIONS}

Calculational methods were used to determine and confirm the thermal conductivity of the concrete as a result of test data to be used in the thermal model. The methods used are as follows:

\section{Transient Line Source Method}

During the initial heatup transient of the cask, hourly temperature data was recorded. The incremental temperature change with time may be used in the following equation: (Reference C1)

$$
k=\frac{Q}{4 \pi \cdot\left(T_{2}-T_{1}\right)} \text { in } \frac{t_{2}}{t_{1}}
$$

Where:

$$
\begin{aligned}
& Q=\text { Heat supplied per unit length and time, Btu/hr-ft } \\
& T=\text { remperature, }{ }^{\circ} \mathrm{F} \\
& t=\text { Time, hrs. }
\end{aligned}
$$

The use of this expression requires a knowledge of both the heat input and the time-temperature values to determine the thermal conductivity. The heat output from the canister is not constant along its length. Using the test data, incremental calculations for radiation, conduction and convection between the canister and liner indicated that at the canister midplane (El. 128"), Q = 1.22 $Q_{a v e}$. Figure 12 was used to estimate the total decay power $(1.13 \mathrm{~kW})$ at the time of the transient. The canister length (167 inches) was used to obtain the heat output per unit length at the midplane. The conductivity calculated for a time interval between 101 hours and 199 hours of operation using temperature data at a radius of 23 inches in Quadrant 1 at elevation 128 inches was $k=1.50 \mathrm{Btu} / \mathrm{hr}-\mathrm{ft}-{ }^{\circ} \mathrm{F}$. 


\section{Periodical Change of Surface Temperature}

Hourly temperature data was recorded during March 25 to March 28, 1980. The thermal lag time Detween two radii due to the daily solar cycle may be used in the following equation to evaluate the concrete thermal conductivity: (Reference C2)

$$
k=.5 n \operatorname{Cp} \rho\left(\frac{r_{2}-r_{1}}{t}\right)^{2}
$$

Where:

$$
\begin{aligned}
& k=\text { Thermal conductivity, Btu/hr-ft- }{ }^{\circ} \mathrm{F} \\
& n=\text { Frequency of the thermal cycle, } \pi / 12 \text { radians per hour } \\
& C p=\text { Specific heat, } .21 \mathrm{Btu} / 1 \mathrm{~b}-{ }^{\circ} \mathrm{F} \\
& \rho=\text { Density of concrete, } 144 \mathrm{lbs} / \mathrm{ft}^{3} \\
& r=\text { Radial position }\left(r_{2}-r_{1}\right)=1.083 \mathrm{ft} . \\
& t=\text { Lag time between the two radii, } 6.50 \mathrm{hrs} .
\end{aligned}
$$

The average phase lag (maximum to maximum and minimum to minimum) between radii 50 and 37 inches for 4 quadrants and 3 elevations was 6.50 hours. This phase lag is detectable in Figure 21. The resulting conductivity was calculated to be $1.60 \mathrm{Btu} / \mathrm{nr}-\mathrm{ft}-{ }^{\circ} \mathrm{F}$.

Temperature Drop Between Radii 9 and 23 Inches (See Figures 22 and 25) on July 24, 1979 and January 30, 1980

The following equations were used to determine the concrete thermal conductivity for an axial incremental length at the cask midplane: (Reference C3)

$$
\begin{aligned}
& q=\sigma A_{1} F_{12}\left(T_{1}^{4}-T_{2}^{4}\right)+U A_{m}\left(T_{1}-T_{2}\right), \text { Btu/nr } \\
& \frac{U b}{k}=0.0317(G r) 0.37 \\
& k=\frac{q}{2 \pi 1\left(T_{2}-T_{3}\right)} \ln \frac{r_{3}}{r_{2}}
\end{aligned}
$$


Where:

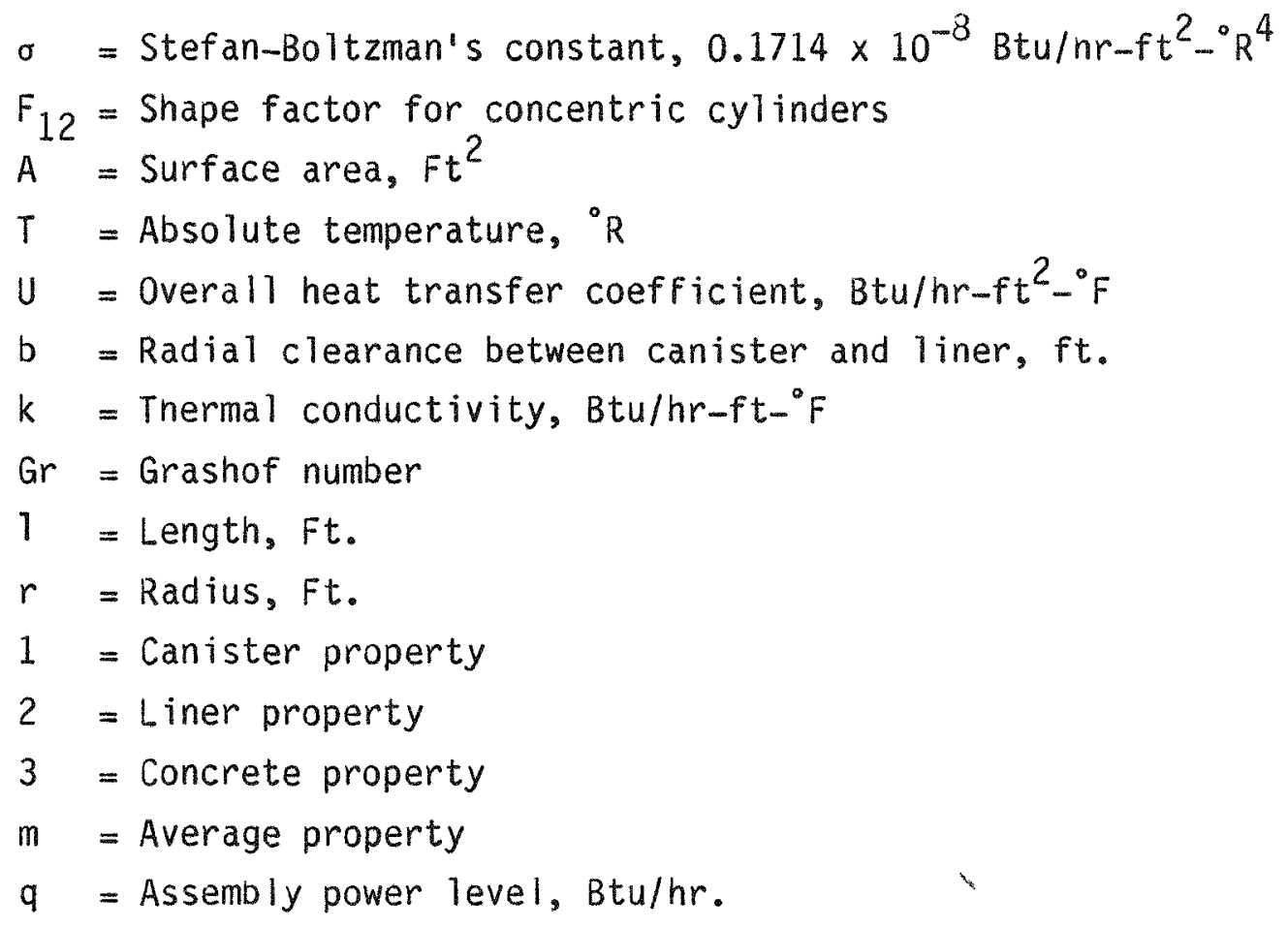

Equation (1) provides the radiation, conduction and convection heat transfer between the canister and liner. Equation (2) provides the overall heat transfer coefficient for an enclosed vertical air space. Equation (3) then provides the concrete thermal conductivity required for the heat transfer obtained in Equation (1).

The decay power obtained from Figure 12 and calculated thermal conductivity for the two dates are:

$\begin{array}{lll}\frac{\mathrm{kW}}{\text { Date }} & \frac{\mathrm{k}}{1.63} \\ \text { July 24, } 1979 & .85 & 1.56 \\ \text { January 30,1980 } & .72 & 1.52\end{array}$


Integration Between Two Constant Isotherms on July 24, 1979 and January 30, 1980 (See Figures 23 and 26)

Numerical integration for volume and mean surface area between two constant temperature lines can be used in the following equation:

$$
q=-\frac{A^{2}}{V} k\left(T_{1}-T_{2}\right), B t u / h r
$$

Where:

$$
\begin{aligned}
& q=\text { Assembly power level } \\
& A=\text { Average area of the isothermal volume } \\
& V=\text { Volume between two constant temperature lines } \\
& T=\text { Temperature } \\
& k=\text { Thermal conductivity }
\end{aligned}
$$

This equation is developed from:

\begin{tabular}{|c|c|c|c|c|}
\hline Date & $\mathrm{kW}$ & $\begin{array}{r}\text { Axial } \\
\text { Loss } \\
\end{array}$ & $\begin{array}{l}\text { Isothermal } \\
\text { Temperatures } \\
\end{array}$ & $\underline{k}$ \\
\hline July 24, 1980 & .85 & $3 \%$ & $110^{\circ} \mathrm{F}$ to $105^{\circ} \mathrm{F}$ & 1.63 \\
\hline January 30,1980 & .72 & $3 \%$ & $70^{\circ} \mathrm{F}$ to $65^{\circ} \mathrm{F}$ & 1.57 \\
\hline
\end{tabular}

$$
q=-\frac{A k\left(T_{1}-T_{2}\right)}{x}
$$

where the average thickness $(x)$ or distance between two isothermal lines is obtained from $V / A$.

The decay power obtained from Figure 12, assumed axial end losses, isothermal temperatures and calculated thermal conductivity for the two dates are:

Comparison of Concrete Thermal Conductivities

The following table provides a summary of the thermal conductivities calculated using the various calculational methods. 
Calculational Method

Holmes and Narver (Table 6)

Transient Line Source

Periodical Change

Conduction in Concrete

Integration Between two Constant I sotherms
Thermal Conductivity

$1.23 / 1.37$

1.5

1.6

$1.63 / 1.56$

$1.63 / 1.57$

References

C1. Y. S. Touloukian, et al, "Thermophysical Properties of Matter, "Volume 1, Plenum Publishing Corporation, 1978.

C2. Jakob, M. and Hawkins, G. A., "Elements of Heat Transfer and Insulation," John Wiley \& Sons, 1950.

C3. Kreith, F., "Principles of Heat Transfer," International Textbook Company, Second Edition, 1965. 